INVESTIGATION OF THE RELATIONSHIP BETWEEN WAVE ACTION AND THE TRANSPORT OF BACTERIA IN FRESHWATER:

IMPLICATIONS FOR THE MANAGEMENT OF AQUATIC AND HUMAN HEALTH RISK

by

Andrew Sousa

Hon. BSc. Applied Chemistry and Biology

Ryerson University, June 2008

A thesis

presented to Ryerson University

in partial fulfillment of the

requirements for the degree of

Master of Science

in the Program of

Molecular Science

Toronto, Ontario, Canada, 2010

(C) (Andrew Sousa) 2010 
I hereby declare that I am the sole author of this thesis. I authorize Ryerson University to lend this thesis or dissertation to other institutions or individuals for the purpose of scholarly research.

I further authorize Ryerson University to reproduce this thesis by photocopying or by other means, in total or in part, at the request of other institutions or individuals for the purpose of scholarly research. 
Ryerson University requires the signature of all persons using or photocopying this thesis. Please sign below and give address and date. 
To my parents Sandra and Manuel, my sisters Ashley and Mellissa, and my friends For believing in me and keeping me strong 


\title{
Investigation of the Relationship between Wave Action and the Transport of Bacteria in Freshwater: Implications for the Management of Aquatic and Human Health Risk
}

\author{
Andrew Sousa, Hon. BSc. \\ Masters of Science, Molecular Science \\ Ryerson University \\ Toronto, Ontario, Canada \\ 2010
}

\begin{abstract}
The sampling regime used to monitor the microbiological quality of water typically involves the collection of whole water samples, where bacteria are assumed to be planktonic. This practice ignores sedimentary pathogen sources and highlights the lack of understanding regarding the effect of shear stress on the erosion of bacteria from sediment particles. This study utilized a wave flume and an environmental test bacterial strain to examine the effect of increasing wave energy on bacterial loading and the partitioning of free-floating and floc-associated bacteria in water. A positive correlation was found between wave energy, total suspended solids, and bacterial loading in water. Experiments examining free-floating and floc-associated bacteria under low $(0.60 \mathrm{~N} / \mathrm{s})$ and high $(5.35 \mathrm{~N} / \mathrm{s})$ wave energy demonstrated the importance of floc as a vector for the transport of bacteria. These results imply that current beach sampling and analysis methods may not reflect overall beach water quality.
\end{abstract}




\section{ACKNOWLEDGMENTS}

I would like to thank my supervisors Dr. Gideon Wolfaardt and Dr. Ian Droppo for their guidance, insightful contribution and valued input. I would like to acknowledge Dr. Martina Hausner for her constructive feedback on my research, and her generosity in providing me with laboratory space. I would also like to thank Christina Jaskot, Brian Trapp, Evan Ronan, Kristen King, and Katrina Bernal for their technical assistance in both running flume experiments and analyzing samples at Environment Canada. This research was supported by contributions from the National Science and Engineering Research Council of Canada (NSERC), Ryerson University, and Environment Canada. 


\section{TABLE OF CONTENTS}

ABSTRACT .. V

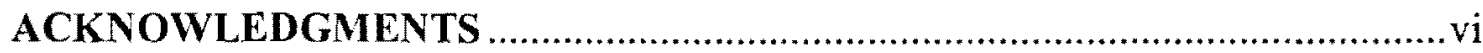

LIST OF TABLES

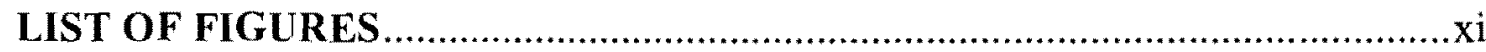

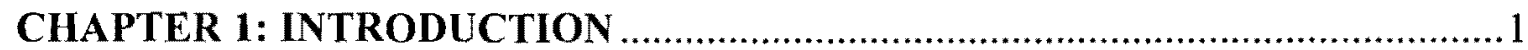

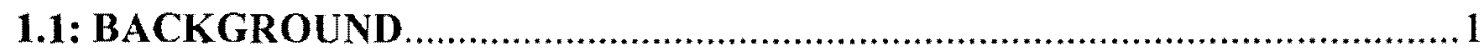

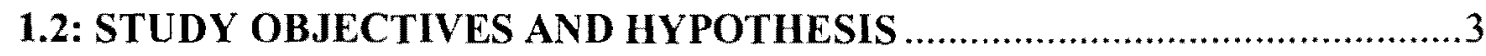

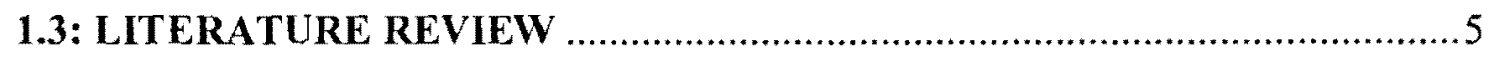

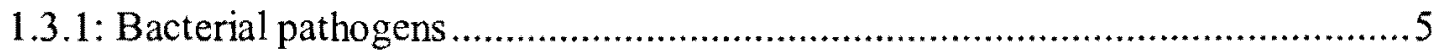

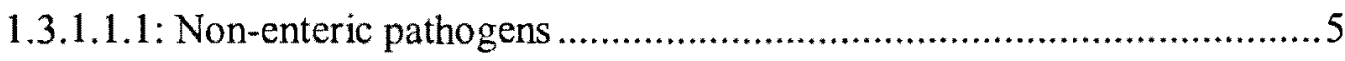

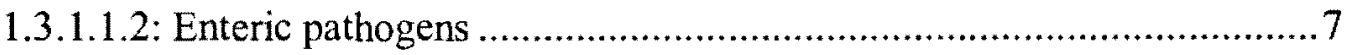

1.3.1.2: Environmental factors controlling pathogen inactivation ......................11

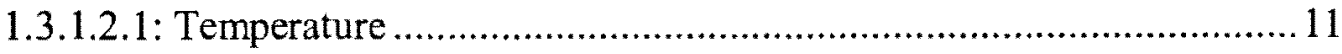

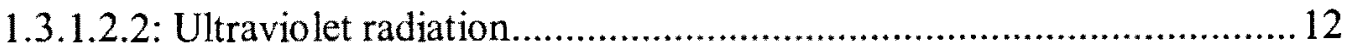

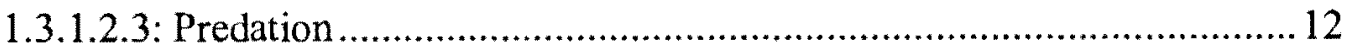

1.3.1.3: Pathogen loading in freshwater......................................................... 12

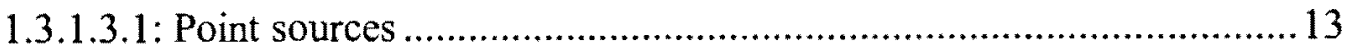

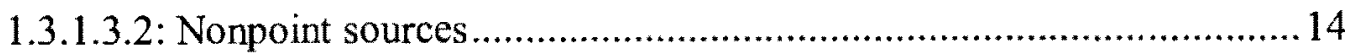

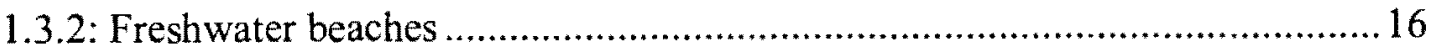

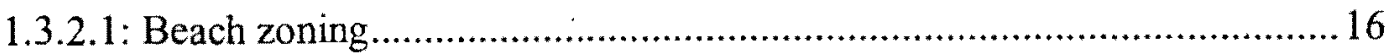

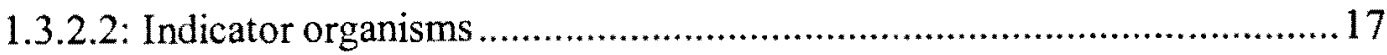

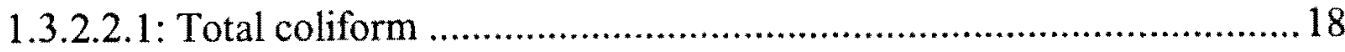

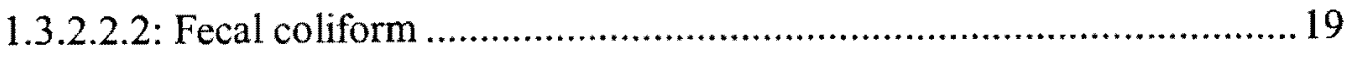

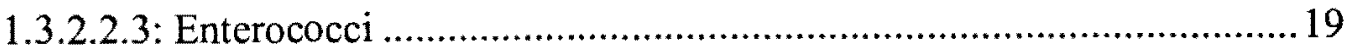

1.3.2.3: Methods used for microbiological analysis of beaches...........................19 
1.3.2.4: Beach closure guidelines in Canada and the United States..... 22

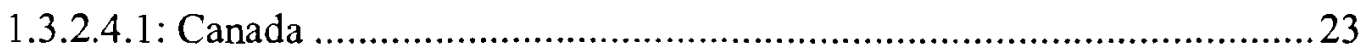

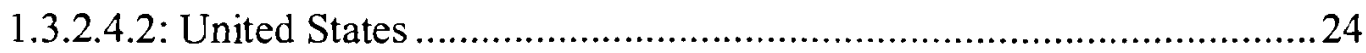

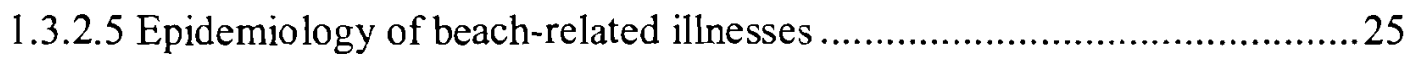

1.3.3: Transport and survival of pathogens in beach environments ........................26

1.3.3.1: Physical processes affecting transport..................................................26

1.3.3.2: Chemical processes affecting transport................................................28

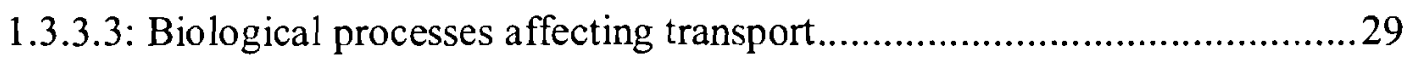

1.3.3.4: Persistence and growth of fecal indicators and pathogens in beach sand 30

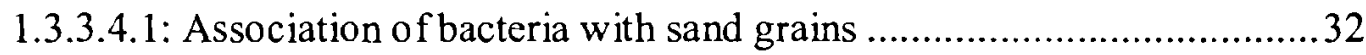

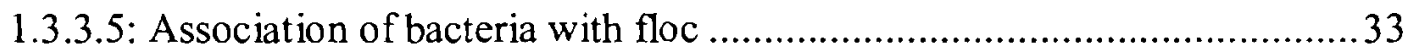

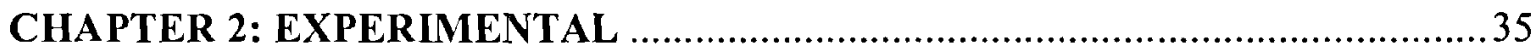

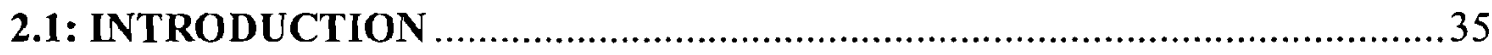

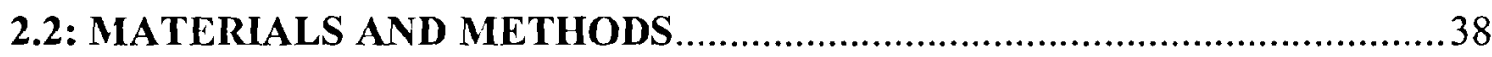

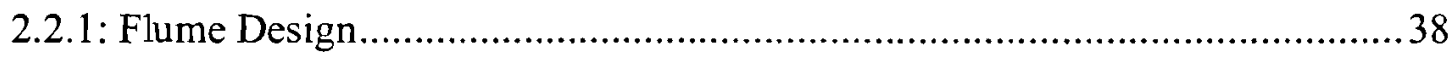

2.2.2: Bacterial Strains, Beach Sand, and Water....................................................39

2.2.3: Flume Conditions and Sampling ............................................................ 40

2.2.3.1: Examining effect of increasing shear on bacterial loading in water ........40

2.2.3.2: Comparison of high $(5.35 \mathrm{~N} / \mathrm{s})$ and low $(0.60 \mathrm{~N} / \mathrm{s})$ wave energy flux to evaluate partitioning of free-floating and floc-associated bacteria .......................43

2.2.3.3: Transport of bacteria in uninoculated beach sand ..................................4 43

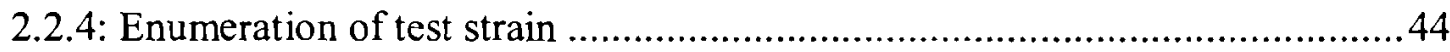

2.2.5: Visualization of bacteria associated with sand grains and floc .....................45

2.2.6: Characterization of indigenous microbial community ..................................48

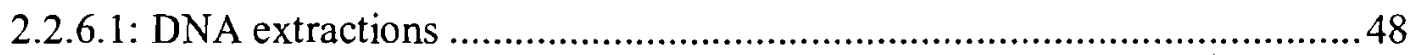

2.2.6.2: PCR amplification of the bacterial 16S rRNA gene ..............................4 48

2.2.6.3: Denaturing gradient gel electrophoresis (DGGE) ..................................49

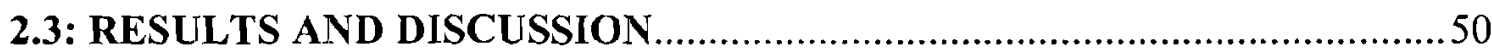




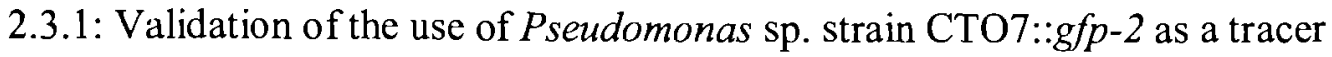

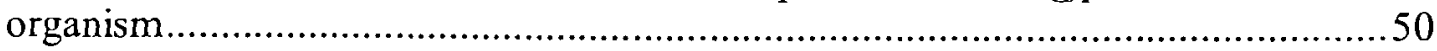

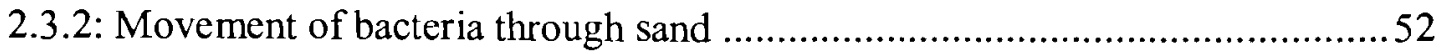

2.3.3: Water and sediment chemical and nutrient analysis ..................................54

2.3.4: Effect of increasing shear on bacterial loading in water ...............................56

2.3.5: Comparison of low $(0.60 \mathrm{~N} / \mathrm{s})$ and high $(5.35 \mathrm{~N} / \mathrm{s})$ wave energy flux on the partitioning of free-floating and floc-associated bacteria ........................................64

2.3.6: Conceptual model of sediment-pathogen dynamics in lake systems:

implications for beach management ................................................................... 71

CHAPTER 3: CONCLUSIONS AND FUTURE DIRECTIONS ..........................74

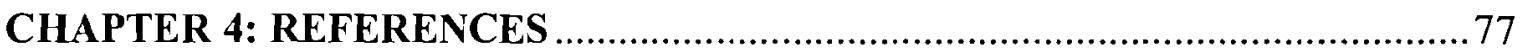

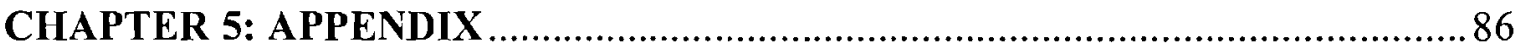

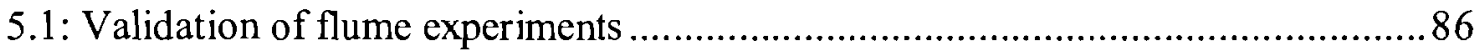

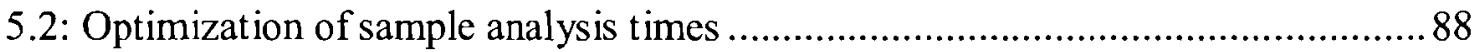

5.3: PCR amplification of bacterial 16S rRNA gene from Sunnyside Beach sand and

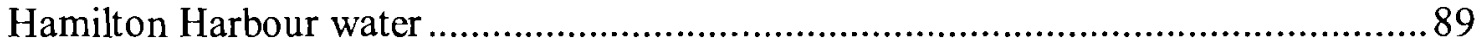

5.4: Effect of increasing shear on sediment-associated bacteria (trials 2 to 4 )............. 90

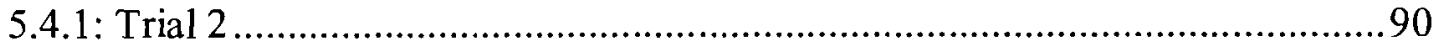

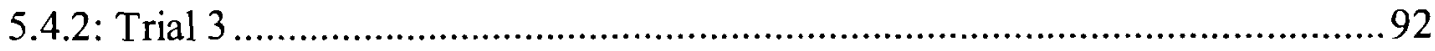

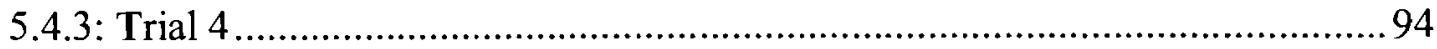




\section{LIST OF TABLES}

TABLE 1. Chemical analysis of Hamilton Harbour water prior to and following exposure to 2,4 , and $6 \mathrm{~cm}$ waves, each for one hour.

TABLE 2. Nutrient analysis for upshore and swash zone Sunnyside Beach sediment after running 2,4 , and $6 \mathrm{~cm}$ waves, each for one hour..

TABLE 3. Partitioning of free-floating and floc-associated cells before, during and after operating flume at $0.60 \mathrm{~N} / \mathrm{s}$.. .66

TABLE 4. Partitioning of free-floating and floc-associated cells before, during and after operating flume at $5.35 \mathrm{~N} / \mathrm{s}$. 


\section{LIST OF FIGURES}

FIG. 1. Four major dynamic zones in the beach environment. MWLW, mean water low water

FIG. 2: Schematic of wave flume

FIG. 3. Schematic of core sampling strategy used in shear experiments.

FIG. 4. Schematic of core sampling strategy used to study transport of the test strain in sand.

FIG. 5. Schematic diagram of an experimental continuous flow set-up.

FIG. 6. CLSM image of unstained (A) and stained (SYTO 9 nucleic acid stain) (B) floc material

FIG. 7. Denaturing gradient gel electrophoresis banding patterns of Sunnyside Beach sand (1) and Hamilton Harbour water (2) bacterial 16S rRNA gene fragments .......52

FIG. 8. Tracking the movement of Pseudomonas sp. strain CTO7::gfp-2 with sand cores taken along five beach transects.

FIG. 9. Cumulative effect of increasing wave energy flux on total suspended solids (TSS) and levels of Pseudomonas sp. strain CTO7::gfp-2 in water.................................58

FIG. 10. Correlation between total suspended solids and Pseudomonas sp. strain CTO7::gfp-2 in water.

FIG. 11 CLSM image of a 72 hour sand biofilm formed in interstitial voids.

FIG. 12. Enumeration of Pseudomonas sp. strain CTO7::gfp-2 from sand cores taken along four beach transects (trial 1).

FIG. 13. Enumeration of floc-associated and free-floating Pseudomonas sp. strain CTO7::gfp-2 in water with low (A) and high (B) wave energy flux.

FIG. 14. Conceptual model of sediment-pathogen dynamics in lake systems. 72

FIG. 15: Validation of mixing procedure used to produce a sediment with a homogenous mix of Pseudomonas sp. strain CTO7::gfp-2.

FIG. 16: Validation that increased cell numbers was associated with wave action rather than cell division.

FIG. 17: Optimization of vortex time used to remove Pseudomonas sp. strain CTO7::gfp-

2 from sand grains.

FIG. 18: Optimization of sonication time used to break up flocs containing Pseudomonas sp. strain CTO7::gfp-2. 
FIG. 19. 1.0\% agarose gel showing $16 \mathrm{~S}$ rRNA PCR products from Sunnyside Beach sand (4) and Hamilton Harbour water (5)............................................................... 90

FIG. 20. Enumeration of Pseudomonas sp. strain CTO7::gfp-2 from sand cores taken along four beach transects (trial 2) ................................................................. 91

FIG. 21. Enumeration of $P_{\text {seudomonas }}$ sp. strain CTO7::gfp-2 from sand cores taken along four beach transects (trial 3 )

FIG. 22. Enumeration of Pseudomonas sp. strain CTO7::gfp-2 from sand cores taken along four beach transects (trial 4) .95 


\section{CHAPTER 1: INTRODUCTION}

\section{1: BACKGROUND}

The quality of Canada's recreational water has implications for both ecological and public health. During the swimming season, recreational water quality at public beaches is assessed by municipal health units for the presence of bacterial indicators, namely total coliform, fecal coliform, enterococci, and/or Escherichia coli. While these indicator organisms are usually non-pathogenic, it is assumed their presence is linked to recent fecal contamination of waterways. The use of indicator organisms is a more time and cost-cffective method than directly analyzing for specific pathogens. Current methods employed for microbiological analysis rely on traditional culture-based methods of detection; however, the application of molecular methods for monitoring recreational water has shown great promise (28).

Recreational water may become contaminated from a variety of point (84) and nonpoint sources $(14,46,48,97)$, including but not limited to combined and sanitary sewer overflows, stormwater runoff from urban areas, agricultural runoff from livestock farms and croplands, bathers, feces from mammalian and avian sources, and bed sediments. Many of the pathogenic bacteria of concern in recreational water are enteric such as Aeromonas spp., Campylobacter jejuni, Escherichia coli O157:H7, Salmonella spp., Shigella spp., Vibrio cholerae, and Yersinia entercolitica, however non-enteric pathogens such as Pseudomonas aeruginosa, Legionella pneumophila, Staphylococcus aureus, and Leptospira spp. may also be present (28).

The sampling regime used for monitoring may involve the collection of whole water samples, where it is assumed that bacteria present in the water are in a planktonic 
state. This practice does not take into account potential sedimentary sources of pathogens, such as beach sand and bed sediments, which have been shown to be temporal sinks and sources of bacteria to the water column (41). Bed sediments may act as a source of pathogens to the water column through re-suspension initiated by fluid shear and wave action $(2,10,48,57,67)$. Additionally, association of bacteria with floc, a complex aggregate containing both biological and inorganic components, has demonstrated the importance of its recognition as a vector for pathogen erosion, transport and delivery within aquatic environments $(22,23)$.

Many field studies have suggested wave action as a potential mechanism for the loading of pathogens in water $(2,10,48,57,67)$ and beach sand $(41,93)$. To date, no study has examined the effect of different wave energy regimes on bacterial transport within freshwater systems. The present study involved the use of a wave flume to model the transport of bacteria under different wave energy regimes. Conducting experiments in a controlled environment allows for easier interpretation of results as compared to studies conducted in the field. In these situations it is often difficult or near impossible to interpret results, due to a large number of overlapping environmental variables that influence pathogen growth and decay kinetics (16). 


\section{2: STUDY OBJECTIVES AND HYPOTHESIS}

The erosion of fecal indicator and pathogenic bacteria from beach sand is not well understood. There is a clear need for a careful examination of the influence of shear forces on bacterial transport (99). In addition, very few studies have examined the attachment of bacteria to particles in freshwater systems $(23,25,59)$. In this study, a wave flume was used to investigate the influence of shear stress imparted by wave action on bacterial transport. This allowed for the development of a conceptual model of sediment-pathogen dynamics in lake systems.

The main objective was to analyze the effect of shear stress imparted by wave action on bacterial loading, and the partitioning of free-floating and floc-associated bacteria in water using the environmental test bacterial strain Pseudomonas sp. strain CTO7::gfp-2 $(6,95)$. This involved the assumption that the flume's inability to simulate longshore drift due to its defined boundaries would not affect bacterial loading in water. It was hypothesized that increasing wave energy will increase the amount of sediment and bacteria in suspension and allow for the development of a correlation between suspended sediment and bacterial load. Increasing wave energy will also affect the partitioning of free-floating and floc-associated bacteria in water.

Five specific objectives were formulated to characterize the system and examine the relationship between wave action and bacterial transport;

1. Visualize the association of the test organism and indigenous bacteria from flocs and grains of Sunnyside Beach, Toronto sand using confocal laser scanning microscopy (CLSM). 
2. Characterize the microbial diversity in Hamilton Harbour water and Sunnyside Beach sand, Toronto sand using denaturing gradient gel electrophoresis (DGGE).

3. Evaluate the transport of the test organism through beach sand under quiescent conditions by taking sand cores along different transects to obtain cell counts.

4. Examine the cumulative effect of increasing wave energy flux $(0.60 \mathrm{~N} / \mathrm{s}, 2.38 \mathrm{~N} / \mathrm{s}$, $5.35 \mathrm{~N} / \mathrm{s}$ ) on the levels of the test organism in the water column and in beach sand.

5. Compare high $(5.35 \mathrm{~N} / \mathrm{s})$ and low $(0.60 \mathrm{~N} / \mathrm{s})$ wave energy flux to evaluate the effect of shear strength on the partitioning of free-floating and floc-associated bacteria. 


\section{3: LITERATURE REVIEW}

\subsection{1: Bacterial pathogens}

Pathogenic organisms are any bacteria, protozoa, virus, worm, or fungi that are capable of causing disease (85). Most pathogenic bacteria range from 0.5 to $10 \mu \mathrm{m}$ in size, and constitute a relatively small group of microorganisms found in the environment (46). Despite being a small group, the presence of bacterial pathogens in recreational waters can lead to adverse effects on human health. Bacterial pathogens may be present naturally or they may enter recreational waters from both point and nonpoint sources of pollution. This literature review will focus on the presence, growth, detection and transport of bacterial pathogens and indicators in freshwater beach environments.

\subsubsection{1: Bacterial pathogens of concern in recreational water}

Recreational water includes swimming and wading pools, natural springs, fresh and marine waters, water parks, and fountains. Fresh and marine water are considered untreated water, while the other recrcational water venues are referred to as treated water (14).

\subsubsection{1: Non-enteric pathogens}

Non-enteric pathogens include Pseudomonas aeruginosa ( $P$. aeruginosa), Legionella pneumophila (L. pneumophila), Staphylococcus aureus (S. aureus), and Leptospira spp. (29). Pseudomonas aeruginosa is a gram negative, rod-shaped, flagellated bacterium that can be found in surface water $(29,68)$. It is often associated with external ear infections (otitis externa), and can be spread into water upon contact with an infected ear. In a study examining the contribution of gulls to recreational water 
quality, it was reported that gulls may contain as many as $10^{4}$ to $10^{6}$ colony forming units (CFU) per gram of droppings (54).

Legionella pneumophila is a gram-negative, aerobic, rod-shaped bacterium that is found in surface water at concentrations of $10^{4}$ to $10^{5}$ cells per liter (29). All Legionella are aquatic bacteria, and they may be free-living or associated with ciliated protozoans and amoebae. Legionellosis is a severe respiratory illness that involves localization of Legionella pneumophila into the phagosomes of alveolar macrophages, and production and export of a cytotoxic exoprotease . This bacterium is also responsible for causing Pontiac fever, a disease that resolves itself spontaneously within two to five days. Symptoms include abrupt onset of fever, headache, dizziness, and muscle pains (96).

Staphylococcus aureus is considered to be the major pathogen of the genus Staphylococcus. It is a gram-positive coccus-shaped organism that is not normally found in significant numbers in water since it requires many organic nutrients for growth and a temperature of approximately $20^{\circ} \mathrm{C}$. It is a halophile that is resistant to many environmental influences, and therefore can survive for long periods of time. The presence of $S$. aureus in recreational water is usually due to human discharges from the mouth, nose, throat, and skin surface (29). A study of bather-related microbial populations in wet sand has shown a significant correlation between $S$. aureus counts and the number of swimmers on the beach. Higher counts were obtained from the wet sand and water in summer, when there was a higher swimmer density, than in winter (66). It has also been reported that gulls may contain as many as $10^{6} \mathrm{CFU}$ per gram of droppings. This value is particularly significant for beaches and recreational waters that are subject to high loads of fecal pollution (54). 
Pathogenic Leptospira strains are released into freshwater environments from the urine of dogs, livestock, and wild animals. The bacteria gain entry into the human body through abrasions, inhalation of aerosols, or ingestion of water while swimming $(14,96)$. They are responsible for causing leptospirosis, an illness that produces symptoms such as fever, headache, chills, vomiting, and occasionally meningitis (84). The ability of these bacteria to survive in harsh environmental conditions is limited, as they are adversely affected by water with a $\mathrm{pH}$ below 6.8. Other limiting factors include exposure to direct sunlight and dehydration (96). An in vitro study confirmed that the majority of pathogenic Leptospira interrogans serovars were able to form a biofilm in aquatic environments, and that the progression of biofilm formation follows that of other biofilms described in literature $(71,80)$. Biofilms may contribute to long-term survival of these pathogens, however, further studies in freshwater habitats is required (71).

\subsubsection{2: Enteric pathogens}

Enteric bacteria tend to die off faster than strains naturally found in surface water because they are unable to successfully compete with the natural community in a low nutrient environment. Some strains however, are able to adapt to these environments by transforming to a viable but nonculturable state $(36,84)$. A bacterium that is viable but nonculturable can be defined as a cell that is metabolically active, but does not divide when cultured using growth medium (36). Some of the enteric pathogenic bacteria of concern include Aeromonas spp., Campylobacter jejuni (C. jejuni), Escherichia coli O157:H7 (E. coli O157:H7), Salmonella spp., Shigella spp., Vibrio cholerae (V. cholerae), and Yersinia entercolitica (Y. entercolitica). 
Aeromonas spp. are gram-negative, rod-shaped, facultative anaerobes that are found naturally in freshwater. High numbers of this organism are found during the warmer months of the year (96). Using a polymerase chain reaction (PCR)-based approach, it has been shown that Aeromonas spp. are natural inhabitants of chironomid egg masses. Chironomids are the most abundant group of insects found in freshwater ecosystems, and their seasonal distribution follows that of Aeromonas spp (78). While the infectious dose of these organisms is not known, contact with members of this genus may result in short term diarrheal disease, cellulitis, and wound infections $(29,54)$. Cytotoxic enterotoxin (Act) has been shown to be a key virulence factor involved in pathogenesis, and one study showed that 32 of 69 environmental isolates contained the cytotoxic enterotoxin gene $(a c t)(70)$.

Campylobacter jejuni is responsible for gastroenteritis, an infection that causes inflammation of the intestine and subsequent diarrhea (84). Gulls have a commensal relationship with this organism, and studies have shown that they may harbour $10^{4}$ to $10^{5}$ CFU Campylobacter spp. per gram of droppings (54). The ability of $C$. jejuni to survive in recreational water is dependent on temperature $(15,29)$. Studies $(12,62,74)$ with various media have shown that there is generally an inverse relationship between bacterial survival and temperature of the medium. Given a Campylobacter jejuni concentration of $10^{4}$ organisms $/ \mathrm{L}$ in water, it was determined that the risk of infection for occupational and sport divers is approximately $1 \%$ per dive when wearing ordinary diving masks (75). Another study in the United Kingdom showed that intertidal zone sediments serve as a reservoir for thermophilic Campylobacter spp. (96). Predation of Daphnia carinata on $C$. jejuni has been shown to result in death rather than sequestration 
of the bacterium. This finding suggests that microbial food webs could potentially be used to regulate bacterial pathogens in aquatic ecosystems (74).

Escherichia coli $\mathrm{O} 157: \mathrm{H} 7$ belongs to the group of enterohemorrhagic $E$. coli, and is responsible for severe diarrhea and abdominal cramps. The primary reservoir of this pathogen is cattle, as they are liable to pick up the bacterium during grazing $(3,84)$. Cattle typically excrete between $10^{2}$ to $10^{5} \mathrm{CFU}$ E. coli O157:H7 per gram of feces (3). The infectious dose is as low as 10 cells, and it is possible that a single mouthful of contaminated water while swimming can cause illness $(14,68)$. One study has shown that E. coli $\mathrm{O} 157: \mathrm{H} 7$ was able to survive better in lake water than in livestock drinking troughs and river water. Survival of the pathogen in drinking troughs might have been affected by the presence of $\mathrm{NO}_{2}{ }^{-}$, a compound that is toxic to E. coli $\mathrm{O} 157: \mathrm{H} 7$ and found in cattle saliva. Other factors such as competition and predation may also have been responsible for persistence of the pathogen in some waters and not in others (3).

The genus Salmonella contains over 2000 serovars that are responsible for salmonellosis. The three variations of this illness include acute gastroenteritis, enteric fever, and septicemia (96). Acute gastroenteritis is characterized by diarrhea, fever and abdominal cramps. Septicemia is characterized by chills, fever, and circulation of bacteria in the blood (84). One study (38) has shown that higher numbers of Salmonella can be isolated from bottom sediments than from the overlying aqueous phase. This may be due to sedimentation and adsorption of organisms to the sands and clays present in the sediment.

Shigella spp. are responsible for causing shigellosis, an illness that is characterized as sudden and severe gastroenteritis (84). The infectious dose for members 
of this genus is from 10 to 100 bacteria (68). An epidemiologic investigation has shown that the most significant reservoir of Shigella in freshwater environments is humans, and that there may be as many as $10^{3}$ to $10^{9}$ organisms per gram of stool (43). Using traditional plating, biochemical tests and quantitative PCR, it has also been shown that the green algae Cladophora is likely a secondary habitat and reservoir of Shigella, Salmonella, and Campylobacter in nearshore water of Lake Michigan. Concentrations of these bacteria ranged from $10^{2}$ to $10^{3}$ cells per gram Cladophora $(42)$.

Vibrio cholerae is responsible for cholera. In this illness, the bacteria adhere to the lining of the small intestine and secrete choleragen, a toxin that produces symptoms of dehydration, abdominal cramps, vomiting, fever, and diarrhea. Expression of the toxin is influenced by environmental factors such as $\mathrm{pH}$ and temperature (68). The infectious dose of this bacterium is $10^{6}$ organisms or more; therefore, the risk associated with recreational activities is low unless the water is highly contaminated (96). The most important reservoir of this pathogen is asymptomatic human carriers and diseased people who shed the organism in their feces (84). Like Aeromonas spp., various serovars of $V$. cholerae have also been shown to inhabit the gelatinous matrix of chironomid eggs. Therefore, these eggs may act as a natural reservoir of both $V$. cholerae and Aeromonas spp. $(36,78)$. Some serovars, such as $\mathrm{O} 139$, are able to degrade the egg masses using an enzyme called hemagglutinin/protease (HA/P) (36).

Yersinia entercolitica is mainly recognized as a foodborne pathogen; however, it can also be found in sewage and polluted waters (84). It is responsible for causing yersinosis, an illness characterized by diarrhea (46). The group most susceptible to this bacterium are children under seven years old (84). The bacterium is able to survive for 
longer periods of time than fecal coliform; therefore, it may be present even when the indicator organism is not (84). This represents a significant health risk to children who often frequent the shallow zones of recreational beaches.

\subsubsection{2: Environmental factors controlling pathogen inactivation}

The viability of pathogenic organisms within the aquatic environment affects their ability to cause illness. There are a variety of environmental stressors that influence survival including temperature, ultraviolet (UV) radiation, and predation by higher-order organisms $(8,10,84,92)$. The most notable inactivation mechanism is exposure to UV light (84).

\subsubsection{1: Temperature}

In order to examine the effects of temperature on $E$. coli survival in sand Beversdorf et al. (8) exposed sand plots inoculated with E. coli JM109 from Bradford Beach, Lake Michigan to temperatures of $4^{\circ} \mathrm{C}, 37^{\circ} \mathrm{C}, 44.5^{\circ} \mathrm{C}$, as well as both room and fluctuating temperature. It was found that there was no difference in survival times between stationary phase and mid-log phase cultures, and that cell numbers increased at all temperatures. Survival of $E$. coli at lower temperatures is consistent with a review by Brookes et al. (10) that suggests freezing may not have a negative impact on E. coli.

In general, increased water temperature decreases the survival of bacteria in surface water (84). This is seen with Campylobacter, as water mesocosm experiments showed longer mean survival times were associated with lower temperatures for this organism (11). A water mesocosm study by Noble et al. (61) also suggested a temperature-dependent inactivation of $E$. coli derived from a wastewater treatment plant. 


\subsubsection{2: Ultraviolet radiation}

UV inactivation of $E$. coli in natural waters can result in DNA damage or oxidation of cellular materials. Noble et al. (61) found that sunlight increased inactivation rates of $E$. coli by at least a factor of 5 in sampling bottles incubated outdoors in natural sunlight compared to those experiments that were not conducted in natural light. In addition, Whitman et al. (92) found that insolation (incoming solar radiation) rather than UV radiation alone decreased $E$. coli counts in the upper surface of water or in shallow clear waters, but not in turbid waters. Insolation is believed to be a more accurate description of the effect of UV on $E$. coli since UV radiation can be scattered by particulate material suspended in both lake water and the atmosphere (92).

\subsubsection{3: Predation}

Grazing of pathogenic bacteria by protozoa or small zooplankton has a variety of implications. Grazing affects the distribution of pathogenic bacteria, as it can be incorporated into a fecal pellet. Rather than the downward flux of the fecal pellet towards the benthos, small fecal pellets from micro and mesozooplankton may remain in suspension and undergo microbial decomposition (10). It is noted however, that when pathogenic bacteria pass through the gut of a predator, they may enter a nonviable state.

\subsubsection{3: Pathogen loading in freshwater}

Pathogens can enter freshwater from both point and nonpoint sources. Point source pollutants of freshwater include sanitary sewer overflow and combined sewer overflow (84). These sources can be traced back to a pipe and are considered one of the largest sources for enteric bacteria of human origin (67). Some examples of nonpoint 
sources include stormwater runoff from urban areas, agricultural runoff from livestock farms and croplands, bathers, fecal droppings from wildlife, and wave action $(14,46,48$, 97).

\subsubsection{1: Point sources}

Combined sewer systems are concentrated in older communities and carry industrial wastewater, domestic sewage, and stormwater. These effluents are conveyed through a single pipe to a treatment facility prior to discharge into surface waters. Combined sewer overflows (CSOs) occur from outfall points during periods of heavy rainfall when the capacity of the treatment facility or sewer system has been reached (84). In these instances, an effective outfall is designed to ensure that the microorganisms present in sewage do not reach recreational areas. Factors such as dispersion, dilution, sedimentation, and inactivation through sunlight, predation, and natural decay, are assumed to decrease the public health risk associated with a CSO. Many factors however, are responsible for the rapid movement of sewage into recreational waters. For example, floating slicks may form when the sewage from the CSO is warmer and of lower salinity compared to the receiving surface water (96).

The typical concentration of indicator E. coli in CSOs is approximately $10^{6}$ $\mathrm{CFU} / 100 \mathrm{ml}$, and greatly exceeds Canadian recreational water guidelines (55). In Ontario, disinfection of CSOs is required in the areas upstream of recreational waters. Some of the possible methods of disinfection include sodium hypochlorite, chlorine dioxide, bromine chloride solution, ozone, and UV light. Regardless of the process used, the concentration of $E$. coli must be reduced to $1000 \mathrm{CFU} / 100 \mathrm{ml}$ (monthly average) (55). 
Sanitary sewers carry domestic and industrial wastewater to a treatment facility. Sanitary sewer overflows (SSOs) involve discharge of raw sewage from municipal sanitary sewer systems. They can be caused during times of severe weather when the system receives stormwater or infiltrating groundwater through cracks in the sewer system. It can also be caused by improper system operation and maintenance (84).

\subsubsection{2: Nonpoint sources}

Stormwater runoff from urban areas is generated from pervious and impervious surfaces during rainfall and snow events (84). The typical concentration of indicator $E$. coli found in stormwater runoff is $10^{3}$ to $10^{5} \mathrm{CFU} / 100 \mathrm{ml}$. Some of the sources of bacteria include domestic pets, urban wildlife, cross-connections between storm and sanitary sewers, deficient solid waste collection and disposal, and sediments and rodents in sewers. Similar to combined sewers, growth of bacteria in storm sewers is also possible when nutrient-rich water becomes stagnant between heavy rainfall events $(27,55)$.

Agricultural runoff from livestock farms and croplands represents another nonpoint source. Pathogens and other indicator organisms can be transported during the movement of sediment and waste particles in overland flow, agricultural drainage tile, and/or ground water flow. Suspended particles that contain bacteria and become deposited at the soil surface can trap more bacteria and enhance the transport of pathogens during runoff. Survival of pathogenic bacteria in soil is influenced by various factors including soil type, temperature, $\mathrm{pH}$, and competition. Studies on enter ic bacteria in agricultural soils have shown that soils with high moisture, fine particles, high organic matter content, a pH of 6 to 7 , and an environment with few competitors, are ideal conditions for enteric microorganism survival (44). There is generally an inverse 
relationship between temperature of the soil and survival of enteric bacteria; however, a study on the survival of fecal coliform in feces-amended sediments has shown greater survival and sometimes regrowth at higher temperatures $(40,44)$.

Bathers themselves can also represent a source of nonpoint pollution, as they are associated with both enteric and non-enteric pathogens. The two factors that are known to influence microbial buildup from bathers in recreational waters include bather density and degree of dilution or water movement $(66,96)$. A high bather density and low dilution represent the highest risk to human health. The release of microorganisms from sediments is poorly understood, however, re-suspension of microorganisms from water users and rainfall is considered a potential health risk (96). Bathers may mix up the sediment and therefore increase the levels of bacteria in water.

Fecal droppings from wildlife (particularly birds) have been shown to harbour high numbers of both pathogens (54) and indicator bacteria (65). For example, various studies have shown that gulls may contain as many as $10^{5}$ to $10^{10}$ E. coli per gram of feces $(31,54)$. The average wet weight of feces excreted by one gull ranges from 11.2 to 24.9 grams per day. Based on this value, one study showed that the approximate average daily deposition of $E$. coli cells from one gull on a Chicago beach was $1.2 \times 10^{10} \mathrm{CFU}$. A study by Bonilla et al. (9) found that a single gull fecal pellet increased the concentration of enterococci in a $3-\mathrm{m}^{2}$ area of the beach 24 hours after exposure. Aside from the bacteria found in their feces, gulls themselves may represent a risk to human health, as they are often in contact with enteric pathogens when feeding at landfills, animal pastures, and sewage disposal sites (31). 


\subsection{2: Freshwater beaches}

Freshwater beaches represent venues for recreational activities. Public health officials are responsible for assessing the human health risks associated with these areas. Surface water quality is currently monitored through the detection of indicator organisms. Specific levels of these indicators should not be exceeded in order to protect human health from bacterial pathogen-caused illness (46). Recreational water quality guidelines for bacterial indicators may vary both among and within countries (see 1.3.2.4).

\subsubsection{1: Beach zoning}

There are four dynamic zones that are recognized in the beach environment (Fig. 1). These include the breaker zone, surf zone, transition zone, and swash zone. The swash zone is the area of the beach in which water moves up and down, while the transition zone refers to the area where backwash (water which descends the beach slope) interferes with the water at the leading edge of the surf zone. The transition zone contains a high concentration of suspended sand grains. The presence of a surf zone is dependent on the slope of the beach. Beaches with a very steep slope may not have a surf zone, while beaches with gentle slopes will have wide surf zones. The breaker zone also has a high concentration of suspended grains, and refers to the area where waves break (5). The breaker zone can be distinguished based on the type of breaking wave. Factors that affect wave breaking include wave height, wave period, and beach slope. Plunging breakers collapse when their wave height is equal to the depth of the water, and are characterized by the front face falling into the base of the wave. Surging breakers occur when the front face and crest of the wave remain smooth and the wave slides up the beach. These waves are frequently encountered on beaches with a steep profile. Spilling breakers occur 
gradually when the wave height is just over half of the water depth (5). It is the energy imparted by wave breaking that potentially mobilizes and transports bacteria, whether they are associated with flocs or free-floating in the water column. Longshore drift is another process that affects the transport of bacteria along beaches and involves the lateral transport of sand and sediments along the shoreline. In this process wind waves approach the shore at an angle and sediment is transported up and along the beach by swash. Acting under gravity, the backwash will then transport sediments at a right angle to the shore. This transport results in a zig-zag movement of sediments along the shore.

\begin{tabular}{|c|c|c|c|c|c|c|}
\hline $\begin{array}{l}\text { Dynamic } \\
\text { zone }\end{array}$ & Oftshore & Breaker & surf & Transizion & Swash & Berm crest \\
\hline Profile & & & & & & MMLY \\
\hline
\end{tabular}

FIG. 1. Four major dynamic zones in the beach environment. MWLW, mean water low water (5).

\subsubsection{2: Indicator organisms}

Bacterial indicators were first used to identify fecal contamination in drinking water supplies. Indicator organisms are now more widely used for monitoring the microbiological quality of water in general. No single indicator is able to successfully predict illness consistently and accurately in all environments because of the large number of organisms that are associated with gastrointestinal illness as well as the variability in pathogen-indicator associations (87). A good indicator organism is present when the pathogens of concern are present, and absent in uncontaminated waters; easy and inexpensive to detect; does not grow in natural surface water; and is present in higher 
numbers than the pathogen $(46,84)$. The use of bacterial indicators is a more time and cost-effective method than directly analyzing for specific pathogens. The indicators are usually not pathogenic themselves, but their presence indicates recent fecal contamination and the increased likelihood of disease-causing organisms being present. Current bacterial indicators include total coliform, fecal coliform, E. coli and enterococci. The United States Environmental Protection Agency (USEPA) is expected to release a revised list of indicator organisms and predicted health effects by 2012. Early studies on the use of molecular methods for the enumeration of bacteria have shown great promise for future beach monitoring applications. Examples of methods include the application of quantitative PCR for the detection of $E$. coli and the use of Bacteroides as a pathogen indicator (28).

\subsubsection{1: Total coliform}

Total coliform consist of fecal and nonfecal bacteria that live in large numbers within the intestinal tract of humans and animals. Common genera include Escherichia, Klebsiella, Enterobacter, and Citrobacter (53). This group of bacteria is not particularly useful for testing recreational water because some species are naturally occuring in plant material or soil that has not been impacted by pollution, and thus their presence in recreational water may not be due to fecal contamination (46). The presence of total coliform bacteria and the incidence of gastrointestinal illness have showed poor or no correlation (84). 


\subsubsection{2: Fecal coliform}

Fecal coliform bacteria are a more fecal-specific indicator and are most commonly used for the testing of recreational freshwater. These bacteria are able to grow and ferment lactose with the subsequent production of gas and acid when grown at $44.5 \pm$ $0.2^{\circ} \mathrm{C}$ within 24 hours. Escherichia coli accounts for greater than $90 \%$ of the fecal coliform group, and is widely used as an indicator throughout Europe, the United States, and Canada. Research conducted by the U.S. EPA in the early 1970s showed a high correlation between gastrointestinal illness and concentrations of $E$. coli in freshwaters (84). E. coli has been found however in the relatively pristine aquatic ecosystems of rainforests, and so may not be a good indicator of fecal pollution in those environments $(53)$.

\subsubsection{3: Enterococci}

The enterococci are also found in the feces of humans and animals and are a useful indicator for both marine and fresh waters due to their environmental resistance and ease of culture (46). This group is able to grow at 10 and $45^{\circ} \mathrm{C}, \mathrm{pH} 9.6$, and in media containing $6.5 \% \mathrm{NaCl}(53)$. The survival rate of Enterococcus spp. through wastewater treatment is higher than that of fecal coliforms and more closely matches the persistence of waterborne pathogenic bacteria (53).

\subsubsection{3: Methods used for microbiological analysis of beaches}

Microbiology laboratories may employ a variety of techniques for determining beach closures. As previously mentioned, current methods involve the detection and enumeration of indicator organisms rather than specific pathogenic bacteria. Culture- 
based methods often involve the use of membrane filtration in conjunction with a growth medium that allows for selection and enumeration of the indicator. For example, $m$-Endo agar can be used to differentiate noncoliform and coliform bacteria, as the latter form pink to dark-red colonies containing a metallic green surface sheen (68). The most probable number (MPN) method can also be used for determining the concentration of coliform bacteria in freshwater. This technique utilizes a series of undiluted and diluted samples containing a growth medium such as lauryl-tryptose broth. A positive response is indicated by turbidity and a yellow colour in the tube, and from the series of positive tubes a statistical estimate of the bacterial density can be determined. Both culture-based and MPN methods require additional biochemical testing to determine the concentration of the specific indicator. This creates a time delay between sample collection and enumeration of at least 24 hours (84).

Another technique used for the identification of indicator bacteria is substrate hydrolysis. In this method the indicator is detected by testing the action of a specific enzyme upon a defined substrate. For example, the presence of $E$. coli can be identified by the action of $\beta$-glucuronidase upon the substrate 4-methylumbelliferyl- $\beta$-Dglucuronide (MUG). If E. coli is present in the sample, the product fluoresces blue under long wavelength UV light. There are several commercially available kits that utilize enzyme substrate technology for the identification of both coliforms and $E$. coli such as IDEXX Laboratories' (Westbrook, ME) Colilert-18 ${ }^{\circledR}$, which can detect these organisms in 18 hours using a combination of defined substrate technology and MPN (84). An issue that is encountered when trying to detect the presence of $E$. coli using defined substrate technology is that not all strains contain the uidA gene required for hydrolysis of MUG. 
Separate studies have shown that $3.4 \%$ of 116 E. coli strains (30) and $2.3 \%$ of $435 E$. coli strains (56) lacked the uidA gene. In addition, certain strains of E. coli O157:H7 are not detected using this technology because $50 \%$ of these strains do not cleave MUG (89). This is particularly problematic since it is predicted that a single mouthful of water contaminated with this organism can cause illness (71). Since traditional methods also introduce a time delay of at least 18 hours, beach closures are not determined in real time. Therefore, when events occur that are known to be a source of beach pollution, such as wet weather, beaches are often closed and remain closed for days even after the cessation of rainfall $(29,55)$. Some Canadian cities with urban beaches have enacted beach closure policies based on the amount of rainfall. For example, beaches along the Rideau River in Ottawa are closed for 1 to 2 days when rainfall is greater than 10 and $20 \mathrm{~mm}$, respectively (29). Improvements to the field of beach monitoring should improve pending the successful application of molecular biology methods for the detection of bacteria (55).

The polymerase chain reaction (PCR) is a useful method for detecting low densities of bacteria. Advantages of the method include its specificity, sensitivity, rapidity and accuracy. It can be used to rapidly identify bacteria that have been isolated by culture-based techniques as well as for direct pathogen detection from environmental samples. A disadvantage of PCR-based methods is that the results of conventional endpoint PCR are only semi-quantitative, as they mostly indicate the presence or absence of the target DNA. PCR is also unable to provide information on the viability of organisms, because it is unable to distinguish DNA present in living bacteria from DNA that persists in the environment. The equipment required for PCR-based methods is also 
costly and requires the operation of skilled technicians, which is why this method is beyond the scope of many local municipalities for routine analysis (84).

Another molecular technique that shows promise for the detection of pathogenic bacteria is the use of oligonucleotide probes. These probes are short sequences of DNA that hybridize to complementary sequences in the sample. Examples of target DNA include virulence genes or a region of a gene that is conserved throughout a particular species of genus. Target DNA can be immobilized on a solid support, and the probes can be labelled with a fluorescent marker or an enzyme to permit detection. Simple gene probe kits are currently available for the detection of Salmonella and E. coli from GeneTrak (Hopkinton, MA), but they are geared towards food and/or clinical applications. Detection is relatively simple and relies on a colorimetric endpoint that can be detected with a photometer. More research is needed before these kits are used to analyze environmental samples. One of the issues preventing their use includes low density of some pathogenic bacteria in freshwater systems, which may be avoided by increased enrichment or by obtaining larger sample aliquots (84).

\subsubsection{4: Beach closure guidelines in Canada and the United States}

Even though Canada and the United States share a common border of four out of the five Great Lakes, the microbiological guidelines for monitoring recreational water quality exhibit some significant differences. These differences exist both between and within the bordering countries. 


\subsubsection{1: Canada}

Health and Welfare Canada provides federal guidelines for Canadian recreational water quality; however, differences can be seen at the provincial and local municipal levels. For example, Health and Welfare Canada suggest that in addition to collecting water samples ( 15 to $30 \mathrm{~cm}$ below the water surface), sediment samples should be collected when there is evidence that bathing beaches could be the source of waterborne disease. The collection of water samples 15 to $30 \mathrm{~cm}$ below the surface of the water is in accordance with studies that show an inverse relationship between water depth and $E$. coli concentration $(49,90)$. The Canadian guidelines also recommend that the sampling regime take into account the times of highest bather density as well as times when high levels of fecal contamination are expected, such as during periods of storm water runoff. The suggested sampling frequency is five samples in no more than 30 days from each specific sampling location (29). Beaches should be closed when the levels of $E$. coli reach 200 colony forming units per $100 \mathrm{~mL}$ sample (13).

In the Ontario Beach Management Protocol there is no mention of sediment sampling, and when the water depth is less than 1 metre it is recommended that samples be taken as far offshore as possible but within the swimming area (64). This guideline not only ignores the concentration of bacteria within sediments, but also ignores evidence that suggests wet sand and sediments in the swash zone provide a favourable environment for enteric pathogens $(26,37,45,66)$. Furthermore, sampling far offshore negates work by Edge and Hill (26) that shows $E$. coli concentrations were highest in ankle-deep water and dropped off rapidly at knee depth and sites further offshore. The Toronto Beaches Plan sets higher municipal standards than those suggested by both 
Health and Welfare Canada and the Province of Ontario. Beaches are sampled every day during the swimming season and are closed when the level of $E$. coli reaches $100 \mathrm{CFU}$ per $100 \mathrm{~mL}(13)$.

\subsubsection{2: United States}

In the United States beaches are closed when E. coli levels reach 235 CFU per $100 \mathrm{~mL}$. Similar to the variation seen in Canada among federal and provincial guidelines, some states have different beach posting guidelines than others. For example, the State of Michigan uses 300 CFU per $100 \mathrm{~mL}$ rather than 235 CFU per $100 \mathrm{~mL}$. Furthermore, the microbial quality of beach sand is also overlooked in some parts of the United States (9, 52). The sampling depth also varies among US states and ranges from approximately 40 to $180 \mathrm{~cm}$ from the surface of the water. A study by (49) has shown that $E$. coli counts along 5 Lake Michigan and 5 Lake Superior beaches were significantly lower as depth increased. As of 2006 water sampling at shallow depths $(30 \mathrm{~cm})$ was not implemented by any Great Lake states because of problems associated with sample collection at this depth, which include disturbance of beach sediments and contamination of water with sand or algae (49). The percentage of Great Lakes beaches that were closed more than $10 \%$ of the season averaged $9 \%$ in the United States and $42 \%$ in Canada during 2006 to 2007. While comparisons of the frequency of beach closings along the Great Lakes are limited due to use of different water quality criteria, the higher number of beach closings in Canada is likely reflective of more stringent guidelines (28). In the United States the Beaches Environmental Assessment and Coastal Health (BEACH) Act required states that have coastal recreational waters (including the Great Lakes) to adopt guidelines that are as protective as the U.S. EPA's criteria in Ambient Water Quality Criteria for 
Bacteria (1986) by April 2004 (83). The criteria stated that a geometric mean of no more than 126 E. coli $/ 100 \mathrm{~mL}$ or 33 enterococci $/ 100 \mathrm{~mL}$ should be exceeded for a geometric mean of 5 samples equally spaced over 30 days. In addition, no single sample from a designated bathing beach should exceed a one-sided confidence limit of $75 \%(83)$. Similar legislation has not been enacted in Canada; however, an updated or amended version of the Guidelines for Canadian Recreational Water Quality is expected to be released soon by Health Canada (28). The current version of the recreational water guidelines dates back to 1992 .

\subsubsection{Epidemiology of beach-related illnesses}

Many epidemiological studies have identified a link between swimmingassociated illness and beach water quality $(50,69,79,86,87)$. In a review of 22 epidemiological studies regarding the health effects from exposure to recreational water,

the authors determined that $E$. coli, enterococci, and fecal streptococci were the indicators that correlate best with health outcome in freshwater environments (69). Another review determined that $E$. coli is superior to enterococci at predicting illness in freshwater environments (69). In many of these studies, the rate of certain symptoms was found to be proportional to the count of fecal indicator bacteria. The most common health problems associated with high indicator counts involve gastro-intestinal symptoms (69). A consistent finding in studies focusing on children is that this group has an elevated risk of illness after recreational water exposure $(69,87,88)$. Using quantitative PCR (QPCR) of enterococci rather than traditional plate counts as a measure of water quality, it was determined that children aged 10 and under, have a higher sensitivity to illness following recreational water exposure. The regression models indicated that out of 1000 swimmers 
exposed, there would be 34 more episodes of gastrointestinal illness in swimmers than in nonswimmers when the enterococcus concentration was 100 QPCR cell equivalents. Further, the number of episodes for swimming children would be 49 more than nonswimming children under the same conditions (88). It is possible that children are more predisposed to illness since they often play for longer periods of time and are more likely to ingest water (96). Young children also spend much of their time in the swash zone and wet sand areas of the beach. Wet sand in particular is enriched with organic substances and provides a favourable environment for enteric pathogens (66).

\subsection{3: Transport and survival of pathogens in beach environments}

\subsubsection{1: Physical processes affecting transport}

Bed sediments may act as a source of pathogens to the water column through resuspension initiated by fluid shear and wave action and/or disturbance of sediments by swimmers $(2,10,48,57,67)$. One study that evaluated the correlation of $E$. coli levels with lake and weather conditions found that wave height was the best single predictor of E. coli levels along the shores of North Beach, Lake Michigan (48). The statistically significant relationship between $E$. coli and wave height suggested that high waves have the ability to draw microorganisms into the overlying water column. The correlation also demonstrated how non-point source pollution can be loaded into beach water from foreshore sands, which has been shown to harvest high numbers of $E$. coli $(31,48,54)$. A separate study by Whitman and Nevers (90) showed that wave height and wind direction were useful for predicting the concentration of $E$. coli in sand. McLellan et al. (57) also found a correlation between $E$. coli levels, wind, and time from last rainfall, but suggested that the correlation may not be solely due to the transport of stormwater- 
derived bacteria but also from the resuspension of viable bacteria deposited in sediments. Fecal indicator bacteria have also been shown to associate with mats of the green alga Cladophora, and the release of Cladophora as a result of wave action is thought to elevate their numbers in water (93).

The settling rate of inorganic particles is governed by Stokes law and is influenced by size and density. The types of particles in suspension greatly impact the settling velocity, and in general denser inorganic particles settle out more rapidly (98). Particle aggregation and flocculation on organic matter or clay minerals leads to sedimentation and also influences pathogen transport between the lake bed and overlying water column. An evaluation of the interaction between $E$. coli and soil particles in runoff found that fecal indicator bacteria were adsorbed predominately to fine clay particles of less than $2 \mu \mathrm{m}$ (59). The aggregation of pathogens to particulate material or the integration of pathogens within a matrix of organic material such as extracellular polymeric substances (EPS) influences pathogen settling $(10,23)$. The potential for microbial adsorption to settleable particles differs for each microorganism (98). A study based on pathogen modeling in Blackstone River, Massachusetts, found that E. coli concentrations in water were weakly correlated with sediment particle size and sediment concentrations (Pearson correlation coefficient of 0.298 at the $99 \%$ confidence interval) (98).

The hydrodynamic boundary layer refers to the gradient of flow velocities that extend between the sediment bed and the bulk liquid. The mass boundary layer is contained within the hydrodynamic boundary layer and refers to the reduced flow velocities found near the sediment bed or biofilm surface (6). If the boundary layer shear 
is greater than the bed shear strength then it will cause erosion, and result in resuspension of sediment and bacteria. Lawrence et al. (51) have shown that in laminar flow conditions, a bulk liquid flow velocity of $10 \mathrm{~cm} / \mathrm{s}$ was reduced to $200 \mu \mathrm{m} / \mathrm{s}$ at a distance of $2 \mu \mathrm{m}$ from the surface of a slide culture chamber. This reduced flow velocity allowed single $P$ seudomonas fluorescens cells to swim up-stream using flagellar-driven motility. The microbial interactions between attached and free-floating cells in this zone of reduced liquid flow velocity raises interesting questions regarding biofilm ecology in the environment (6), and the association of bacteria with particles in suspension in freshwater systems.

\subsubsection{2: Chemical processes affecting transport}

The surface charge of particles plays a key role in particle-particle interactions within the water column and thus influences flocculation and settling. The net surface charge of a particle is measured as electrophoretic mobility and expressed as zeta potential. Particles in surface waters with a neutral $\mathrm{pH}$ typically have a zeta potential of approximately -15 to $-30 \mathrm{mV}$ and are in general negatively charged. The ability of a particle to neutralize the net negative charge contributes to its removal through flocculation and sedimentation. Negative particles with positive cations in solution can result in attraction or flocculation, which results from the reduction of the electrochemical double layer. One study found that Cryptosporidium oocysts (a protozoan pathogen) found in surface waters have a zeta potential of $-35 \mathrm{mV}$ and therefore may not adsorb well to natural clays in the environment (63). This research contrasts with results by Searcy et al. (77) that suggests oocysts of the ubiquitous pathogen Cryptosporidium parvum are able to attach to suspended sediments and that rate 
of sedimentation was dependant on the type of sediment. Sediments containing kaolinite or iron oxide had higher sedimentation rates than those containing illite, which had a more negative zeta potential.

\subsubsection{3: Biological processes affecting transport}

The biological processes affecting transport include active adhesion/detachment and chemotaxis. Microorganisms exhibit active adhesion and detachment in response to nutrient availability, survival mechanisms, and/or growth (35). A recent biofilm study using Pseudomonas sp. CTO7::gfp-2 by Bester et al. (7) found that the average per cell $\mathrm{CO}_{2}$ production rate (measure of metabolic activity) was significantly higher for the shear-susceptible layer of cells that were removed with an air bubble and transferred to a planktonic state with an unrestricted access to nutrients and oxygen. In a study investigating the protective characteristics of bentonite clay it was found that grazing of protozoa on Rhizobium leguminosarum was greatly reduced in the clay-amended soil. Results inferred that bentonite clay may induce the formation of micro-niches which cannot be reached by protozoa (39).

Chemotaxis refers to the movement of microorganisms in response to a chemical gradient (35). Microorganisms swim toward increasing concentrations of beneficial substances and away from high concentrations of harmful substances such as toxins. It is the change in the number of cell-surface receptors with bound substrate that provides information to the cell regarding chemical gradients. For example, amino acids bind directly to methyl-accepting chemotaxis proteins (MCPs) that are located in the cytoplasmic membrane (58). Chemotaxis is a complex transport mechanism that is both organism and nutrient-specific (35). Mercer et al. (58) demonstrated that chemotaxis is an 
important transport mechanism in oligotrophic environments, as $E$. coli $\mathrm{K}-12$ (NR50) exhibited a higher chemotactic sensitivity coefficient at low growth rates near $0.1 \mathrm{hr}^{-1}$. Bioflocculation refers to the association of bacteria with extracellular polymeric substances (EPS). This binding of particles and bacteria has implications for bacterial erosion, transport, and fate in recreational waters (see 1.3.3.5).

\subsubsection{4: Persistence and growth of fecal indicators and pathogens in beach sand}

Many field studies have investigated the persistence and growth potential of pathogen indicators, namely $E$. coli and enterococci, in beach sand $(1,2,8,9,37,41,52$, $57,90-92,94,99)$. Aquatic sediments are seen as a reservoir for enteric microorganisms since they provide favourable nutrient and moisture conditions and protection from sunlight inactivation and predation $(2,37,66)$. The foreshore refers to sand that is exposed to the air at low tide and is underwater at high tide. Using plate counts for enumeration of E. coli, Whitman and Nevers (90) found that concentrations in the foreshore sand of 63rd Street Beach, Lake Michigan were significantly higher than counts obtained from water samples. This was also observed in a separate Lake Huron beach study by Alm et al. (2). Whitman and Nevers (90) found that elevated levels of $E$. coli were present in sand in early April, which had a mean temperature of $4.9^{\circ} \mathrm{C}$. This suggested that foreshore sands are capable of supporting a high density of $E$. coli for sustained periods (90). A study by Edge and Hill (26) also found high E. coli

concentrations (as much as $10^{5} \mathrm{CFU} / \mathrm{g}$ dry sand) in foreshore sand of Hamilton Harbour, Lake Ontario. Results by Ishi et al. (41) showed that the concentration of E. coli was below detection limit for foreshore sands along Duluth Boat Club Beach, Lake Superior in early April. This could have been due to the presence of ice covering the beach sand, 
which would have prevented it from receiving lake water. The association of indicator bacteria with Cladophora can also influence pathogen loading as washed up algae may become buried in the sand by wave action. Once buried, the indicator bacteria may multiply due to protection from sunlight and dessication, and access to the nutrients made available from decomposing mats (93). It is believed that loss of $E$. coli from foreshore sand is likely due to aqueous dilution, cell dispersal or death, or sediment erosion and deposition (90).

In a study using a controlled laboratory microcosm, Alm et al. (1) found that $E$. coli densities increased from $2 \mathrm{CFU} / \mathrm{g}$ to greater than $2 \times 10^{5} \mathrm{CFU} / \mathrm{g}$ after 2 days, and remained at $10^{5} \mathrm{CFU} / \mathrm{g}$ for at least 35 days in sterile autoclaved beach sand incubated at $19^{\circ} \mathrm{C}$. This in situ study revealed the effect of temperature on the growth of $E$. coli and confirmed field observations that showed increased numbers of $E$. coli in foreshore sands during the hot summer months $(26,90)$. Research by Sampson et al. (73) indicated that increasing water temperatures were not associated with increasing concentrations of $E$. coli in the water column for 26 beaches along Lake Superior. Ishii et al. (41) also found that higher $E$. coli concentrations were observed in the fall months when compared to the spring. Since the mean temperatures between the two seasons were similar, these results suggested that wave action throughout the swimming season may have been responsible for the transport of E. coli from water to beach sand.

In a separate microcosm study by Lee et al. (52) it was shown that the survival of fecal indicator bacteria was also dependant on the organic content in the sediment, as autoclaved California beach sand with an organic content of approximately $1 \%$ showed higher $E$. coli counts compared to beach sand with an organic content of $0.7 \%$. In a study 
of beach sand from 55 beaches along the California coast, Yamahara et al. (99) found that moist, carbon-rich, fine sands were more likely to harbour higher quantities of $E$. coli. Whitman et al. (92) found increased numbers of $E$. coli in moist sand relative to dry sand, which may have been due to resuscitation of viable but non culturable cells. This finding agrees with previous work that correlates low moisture with decreased cell survival and high moisture content with resuscitation or cell propagation (92).

A study by Hartz et al. (37) reported the relative percentage of attached and interstitial bacteria for wet and dry beach sand collected from Hollywood Beach, Florida. It was determined that there were 6.9 times more bacteria attached in wet sand, and 5.4 times more bacteria attached in dry sand than loosely attached or free bacteria. A pilot epidemiological study by Bonilla et al. (9) demonstrated a dose response between gastrointestinal (GI) illness and time spent in wet sand and time spent in water. The lack of correlation between GI illness and time spent in dry sand may indicate that indicator organisms and pathogens may re-suspend from wet sand and cause illness, though this is only a preliminary finding.

\subsubsection{1: Association of bacteria with sand grains}

The persistence of bacteria in foreshore sands can be attributed at least in part to biofilm formation. The large surface area of sand grains and the microhabitats provided by cracks and crevices provide microorganisms with a variety of niches that can be exploited for growth and survival (9). In particular, sand grains provide a site for attachment and access to nutrients and carbon in the grain crevices. Additionally, these surfaces have been shown to concentrate nutrients, giving bacteria a nutrient-rich environment upon attachment to a particle (4). Another benefit is that biofilms also 
provide protection from predation by grazers (37). There is also a cohesive component to the sand (silts and clays), which is the component that is re-suspended with wave action. The silt and clay fraction has a much larger surface area to mass ratio than sand, and therefore contains more nutrients.

\subsubsection{5: Association of bacteria with floc}

Flocs that are found within the water column are composed of a viable and nonviable biological component, inorganic particles, and water. The viable biological fraction is primarily composed of bacteria, while the non-biological material is detritus and extracellular polymeric substances (EPS). Clay particles contribute to the inorganic fraction, and water can be found flowing through pores or trapped within the internal structure (18). Bacteria are known to produce EPS for attachment to surfaces, and the production of EPS is involved in the primary stage of bacterial colonization (80). The presence of EPS fibrils within flocs is one mechanism facilitating the binding of sediment particles and also allow for nutrient assimilation, which is of importance to bacterial cells that colonize the floc (19). The complex 3D network of EPS fibrils is thought to be responsible for creating pores, which in turn affects floc density (18). Floc development is highly dependent on interacting biological, physical, and chemical properties including dissolved organic matter, $\mathrm{pH}$, redox potential, turbulence, and suspended solids concentration (21).

The process of flocculation/aggregation within the water column directly influences the downward flux of sediment particles by increasing settling velocities (18, 22). This alters the distribution of contaminants and organisms between the bed sediment and overlying water column, which is of particular concern when the organisms 
associated with the floc material are pathogenic (23). A study by Droppo et al. (22) showed that counts of $E$. coli and Salmonella were elevated within suspended sediment relative to the sediment bed. A strong association of bacteria with the EPS and clay matrix was shown for suspended floc from South Nation River, near Ottawa, Canada. Studies have demonstrated the need to conceptualize floc as a vector for pathogen erosion, transport and delivery within aquatic environments $(22,23)$. 


\section{CHAP'TER 2: EXPERIMENTAL}

\section{1: INTRODUCTION}

Monitoring the microbiological quality of recreational water is vital for assessing the human pathogen health risk at public beaches. Current monitoring practices rely on bacterial indicators, namely total coliform, fecal coliform, enterococci, and/or Escherichia coli. While these indicators are usually not pathogenic themselves, their presence is linked to recent fecal contamination of waterways (96). Currently, sample analysis relies on traditional culture-based methods of detection, however new molecular methods have shown great promise for beach monitoring applications (28). Although Canada and the United States share a border for 4 out of the 5 Great Lakes, differences exist between their water quality guidelines. The percentage of Great Lakes beaches that were closed more than $10 \%$ of the season averaged $9 \%$ in the United States and $42 \%$ in Canada during 2006 to 2007 , respectively. While comparisons of beach closure frequency is limited due to use of different water quality criteria, the higher number of beach closings in Canada may be reflective of more stringent guidelines (28). In Canada, federal guidelines state that beaches should be closed when the concentration of $E$. coli reaches 200 colony forming units per $100 \mathrm{~mL}$, whereas in the United States beaches are often closed when $E$. coli concentration reaches 235 colony forming units per $100 \mathrm{~mL}$. (28). Some municipalities such as Toronto have enacted more stringent guidelines (13). Many of the pathogens of concern in recreational water are enteric in nature and include Aeromonas spp., Campylobacter jejuni, Escherichia coli O157:H7, and Salmonella. However, the presence of non-enteric pathogens such as Pseudomonas aeruginosa, Staphylococcus aureus, and Leptospira sp, also pose concern (28). Pathogen 
loading of freshwater may be from a variety of point (84) and nonpoint sources $(14,46$, 48,97 ), including combined and sanitary sewer overflows, stormwater runoff from urban areas, agricultural runoff from livestock farms and croplands, bathers, fecal droppings from wildlife, and bed sediments.

A consistent finding in studies focusing on children found their risk of illness was elevated after recreational water exposure $(69,87,88)$. It is possible that children are predisposed to illness since they often play for longer periods of time and are more likely to ingest water (96). Young children also spend much of their time in the swash zone and wet sand areas of the beach. Wet sand in particular has been shown to be enriched with organic substances, and provides a favourable environment for enteric pathogens (66). The Ontario Beach Management Protocol states that when the water depth is less than 1 metre, it is recommended that samples be taken as far offshore as possible but within the swimming area (64). This guideline may pose a greater health risk to children, and also ignores research that showed $E$. coli concentrations being highest in ankle-deep water with lower concentrations being found at knee depth and sites further offshore (26).

Many field studies have investigated the persistence and growth potential of pathogen indicators, namely $E$. coli and enterococci, in beach sand and sediments $(1,2,8$, $9,37,41,52,57,90-92,94,99)$. The persistence of bacteria in foreshore sands can be attributed at least in part to biofilm formation, as the large surface area of sand grains and the microhabitats provided by cracks and crevices provide microorganisms with a variety of niches that can be exploited for growth and survival (9), and protection from predation by grazers (37). In addition, association of bacteria with floc, a complex aggregate containing both biological and inorganic components, has demonstrated the importance 
of recognizing it as a vector for pathogen erosion, transport and delivery within aquatic environments $(22,23)$. Although many studies have listed wave action as a potential mechanism of bacterial loading in water $(2,10,48,57,67)$ and foreshore sand $(41,93)$, only a few field studies have attempted to measure the contribution of wave action to elevated levels of bacteria in water (48). Furthermore, interpretation of results from field studies is often difficult or near impossible due to a large number of overlapping environmental variables that influence pathogen growth and decay kinetics (16). The erosion of fecal indicator and pathogenic bacteria from beach sand is not well understood, and there is a clear need for a careful examination of the influence of shear forces on bacterial transport (99). This study involved the use of a wave flume and an environmental test bacterial strain, Pseudomonas sp. strain CTO7::gfp-2, to analyze the effect of shear stress imparted by wave action on bacterial loading in water, and the partitioning of free-floating and floc-associated bacteria. 


\section{2: MATERIALS AND METHODS}

\subsection{1: Flume Design}

The wave flume measured $13 \mathrm{~m}$ in length by $0.3 \mathrm{~m}$ in width by $0.5 \mathrm{~m}$ in height (Fig. 2). The test area of the flume was the wash zone, which was separated from the rest of the flume by a flexible wave energy transmitting membrane (WETM). The WETM allowed energy rather than materials to pass through the propagation channel to the wash zone. The flume contained a beach with a slope of 1:10, and a maximum water depth of $15 \mathrm{~cm}$. A wave generator was used to create a $1 \mathrm{~Hz}$ sinusoidal wave. The signal was passed through an attenuator, which was used to adjust wave height and shear. The structure of the waves was monitored using wave staffs capable of converting water height to voltage. There were two wave staffs up-wave of the WETM and one between the beach and WETM.

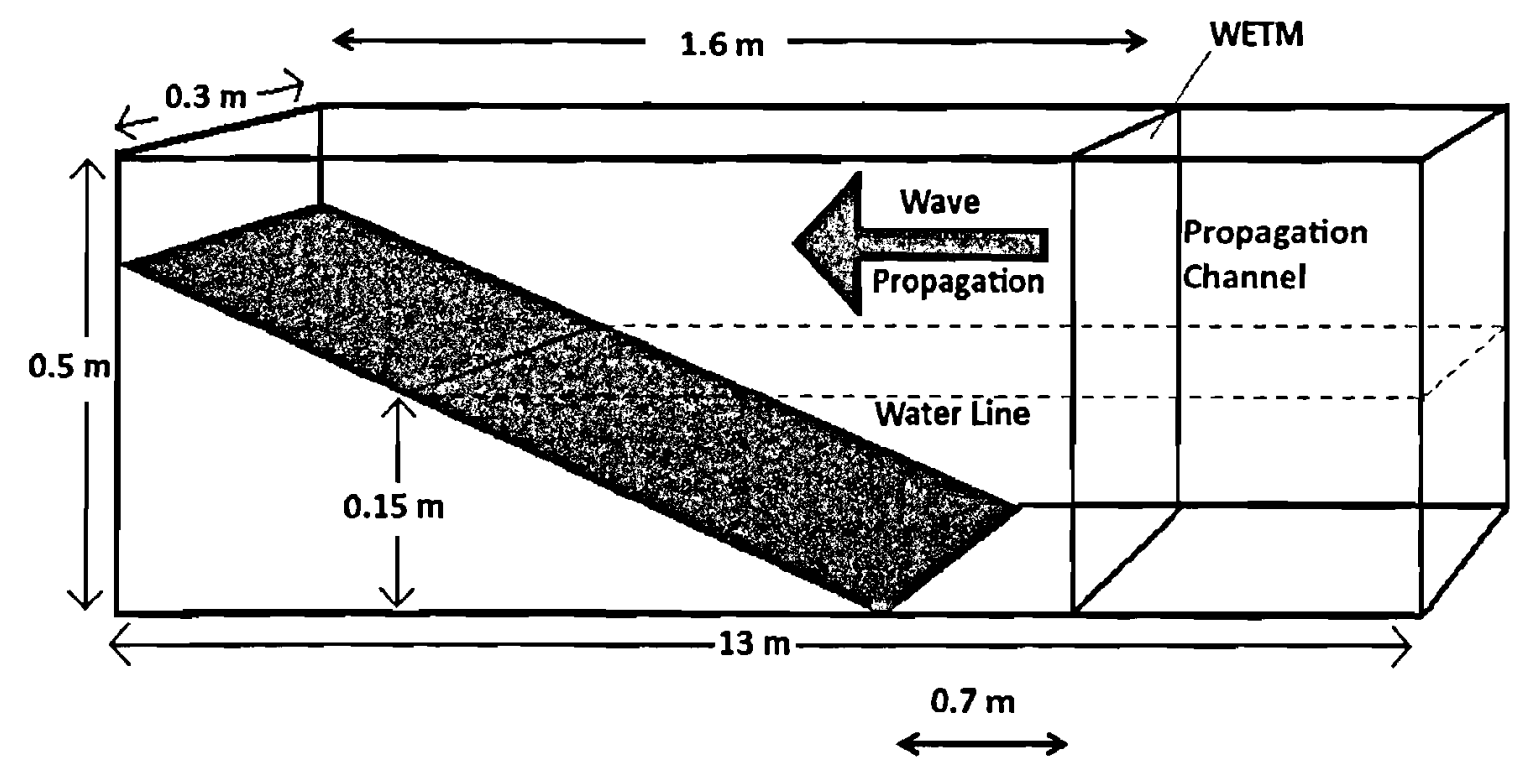

FIG. 2: Schematic of wave flume. WETM: wave energy transmitting membrane. 


\subsection{2: Bacterial Strains, Beach Sand, and Water}

Pseudomonas sp. strain CTO7::gfp-2 (GenBank Accession No. DQ 777 633) was used to track bacterial transport in all experiments. The inoculum was grown in $500 \mathrm{~mL}$ of sterile $3 \mathrm{~g} / \mathrm{L}$ tryptic soy broth (EMD Biosciences) for $15 \mathrm{~h}$ in a tabletop shaking incubator $(250 \mathrm{r} / \mathrm{min})$ at $30^{\circ} \mathrm{C}$. The stable and site-specific insertion of green fluorescent protein (GFP) was verified previously using polymerase chain reaction (PCR) and microbial growth curve analysis $(6,95)$. Previous studies have also demonstrated the ability of the strain to form biofilms on such surfaces as Plexiglas (7) and borosilicate glass (6). Beach sand was obtained from the swash zone at Sunnyside Beach, Toronto, Ontario, Canada, and was used for experiments that examined the effect of shear stress on bacterial loading in water and the partitioning of free-floating and floc-associated bacteria (see 2.2.3.1 and 2.2.3.2). This sediment was selected since Sunnyside Beach was closed for 36 to $69 \%$ of the swimming season (2005-2008) due to high levels of E. coli (13). Water from Hamilton Harbour, Burlington, Ontario, Canada was used in the wash zone, while dechlorinated tap water was used for wave propagation in all experiments. Water chemistry was analyzed at the National Laboratory for Environmental Testing (Environment Canada, Burlington, Ontario, Canada) before and after running waves ( 3 hour cumulative run time) as described in 2.2.3.1. Concentrations of $\mathrm{Ca}^{2+}, \mathrm{Mg}^{2+}, \mathrm{Na}^{+}, \mathrm{K}^{+}$ were analyzed using atomic absorption spectroscopy. $\mathrm{F}^{-}, \mathrm{Cl}^{-}$, and $\mathrm{SO}_{4}{ }^{2-}$ were analyzed using column chromatography containing an anion exchange resin $\left(\mathrm{CO}_{3}{ }^{2} / / \mathrm{HCO}_{3}{ }^{-}\right)$. Soluble reactive phosphorus (SRP) was determined using an automated continuous segmented flow analyzer, while dissolved inorganic carbon/dissolved organic carbon (DIC/DOC) concentrations were determined using a UV-persulfate TOC Analyzer 
(Pheonix $8000^{\mathrm{TM}}$ ). Sunnyside Beach sediment from the swash zone and far upshore (see Fig. 3) was analyzed for inorganic and organic carbon and organic nitrogen using a PE $2400 \mathrm{CHN}$ analyzer after running the flume experiment detailed in 2.2.3.1. Particulate inorganic carbon, organic carbon, and nitrogen was reported in mg and converted to a percentage based on the initial concentration of suspended solids in the sample. To ensure that fluorescent colonies represented only the test strain, bacterial colonies originating from Sunnyside Beach sediment and Hamilton Harbour water were screened for autofluorescence using the GFP-2 filter of a fluorescent dissection microscope (Leica). It was necessary to verify that there was no significant growth by Pseudomonas sp. strain CTO7::gfp-2 in Hamilton Harbour water, which could impact the results obtained during the wave scenarios. For confirmation, batch experiments with Hamilton Harbour water were performed in $250 \mathrm{~mL}$ Erlenmeyer flasks in a shaking incubator $(250 \mathrm{r} / \mathrm{min})$ for $8 \mathrm{~h}$ at room temperature. Ottawa Sand (Bell and Mackenzie Co. Ltd., Hamilton, Ontario, Canada) was used in experiments that examined the transport of the test strain through sand (see 2.2.3.3). The sand consisted of $99.88 \% \mathrm{SiO}_{2}, 0.015 \% \mathrm{Fe}_{2} \mathrm{O}_{3}, 0.050 \% \mathrm{Al}_{2} \mathrm{O}$, $0.010 \% \mathrm{CaO}, 0.003 \% \mathrm{MgO}, 0.003 \% \mathrm{~K}_{2} \mathrm{O}, 0.007 \% \mathrm{Na}_{2} \mathrm{O}$, and $0.1 \%$ clay and silt. The screen analysis provided by the manuiacturer stated that $62 \%$ of the particles passed through a 70 -mesh sieve (particles smaller than $0.210 \mathrm{~mm}$ ), whereas $38 \%$ of the particles were retained by a 70 -mesh sieve (particles larger than $0.210 \mathrm{~mm}$ ).

\subsection{3: Flume Conditions and Sampling}

\subsubsection{1: Examining effect of increasing shear on bacterial loading in water}

Approximately $120 \mathrm{~L}$ of beach sediment was homogenized with $10^{9}$ cells (total cell count) of Pseudomonas sp. strain CTO7::gfp-2 using a cement mixer. The inoculated 
sediment was then left to stand for 72 hours in six 20 L buckets (with the lid kept off) at room temperature. The sediment/microbe mixture was then re-homogenized in the cement mixer and laid down in the wash zone of the flume to form the beach. Hamilton Harbour water was collected in large barrels and stored at $4{ }^{\circ} \mathrm{C}$ until use in the flume. Once the sediment was laid down in the flume eighty L of Hamilton Harbour water was carefully siphoned into the wash zone to allow for minimal disturbance of inoculated sediment. Dechlorinated tap water was added to the propagation channel and the system was left for one hour. To assess the cumulative effect of shear stress on bacterial loading in water, the flume was sequentially operated at 2,4 , and $6 \mathrm{~cm}$ wave height, each for one hour. As shear stress is difficult to determine in a wave-breaking environment, a wave energy flux was used to represent a measure of shear as described by Turker and Kabdash (82). The wave energy flux, $P$ (in Newton per second), per unit length of wave crest can be defined as, $P=\frac{1}{8} \rho g H^{2}(g h)^{1 / 2}$

where $\rho$ represents water density, $g$ represents acceleration due to gravity, $H$ is the wave height, and $h$ is the water depth. Wave heights of 2,4 , and $6 \mathrm{~cm}$ with a $15 \mathrm{~cm}$ water depth were equivalent to a wave energy flux of $0.60,2.38$, and $5.35 \mathrm{~N} / \mathrm{s}$, respectively. After every wave scenario, sterile $10 \mathrm{~mL}$ syringes (BD Biosciences) with the front tip cut off were used to core $6 \mathrm{~cm}$ deep into the sediment along transects 1-4 (Fig. 3). Triplicate water samples were collected in $15 \mathrm{~mL}$ polypropylene tubes (BD Biosciences) every 15 minutes for determination of culturable cell counts (see 2.2.4). Duplicate $50 \mathrm{~mL}$ water samples were collected for determination of suspended sediment concentration by filtration through pre-dried and tared $0.45 \mu \mathrm{m}$ filters (Millipore). Plankton chambers were 
filled after every wave intensity for visualization of flocs and determination of particle size distribution using a combination of microscopy, photography, and digitization as previously described (24).

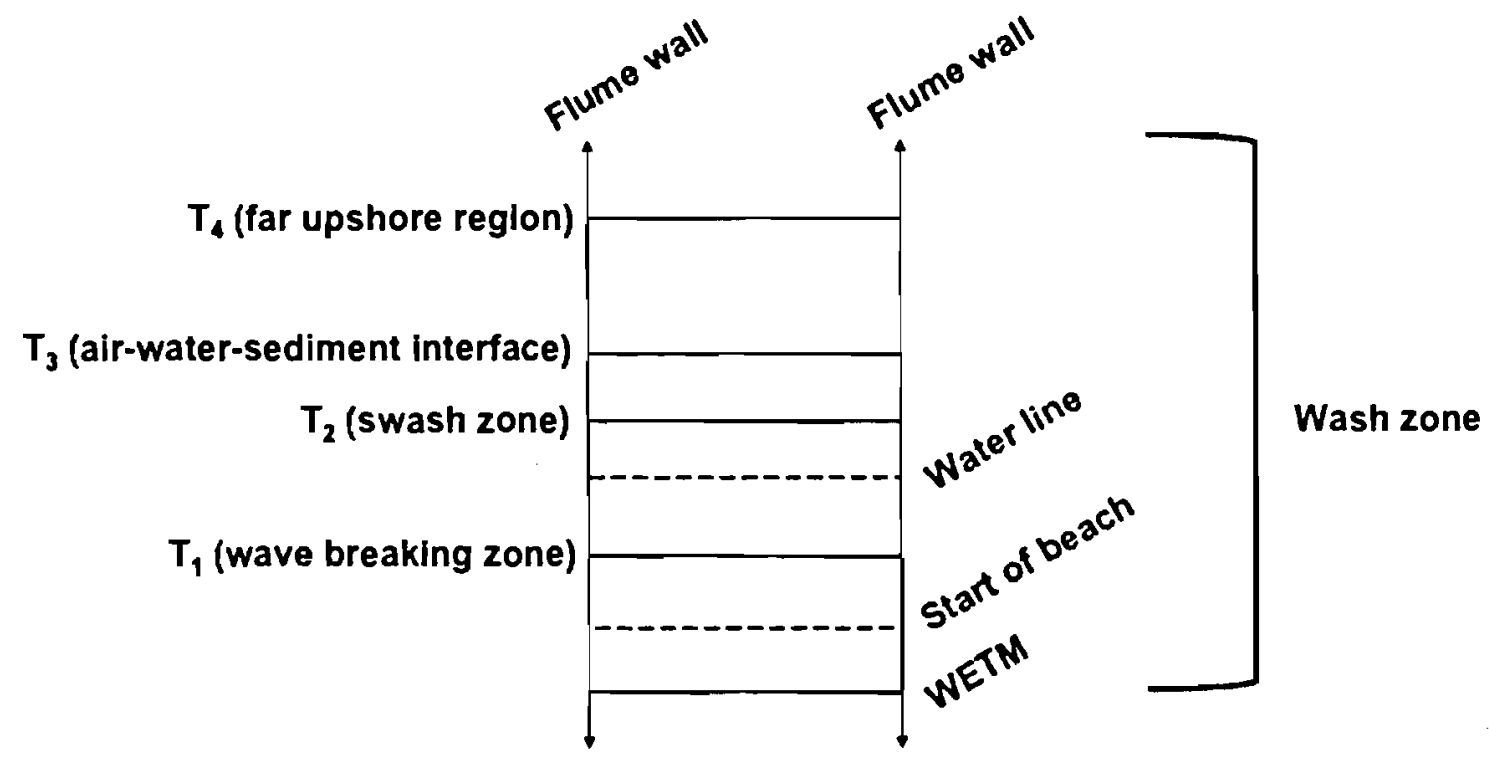

FIG. 3. Schematic of core sampling strategy used in shear experiments. Transect $1\left(\mathrm{~T}_{1}\right)$ refers to below water line, and was roughly the wave breaking zone. Transect $2\left(\mathrm{~T}_{2}\right)$ refers to the swash zone, which was the area where the shoreline moves back and forth as waves meet the shore. Transect $3\left(\mathrm{~T}_{3}\right)$ characterized the air-water-sediment interface, and was the furthest area where water travelled up the beach. The exact location of transect 3 varied with wave energy, as higher wave energies pushed water further up the beach. Transect $4\left(\mathrm{~T}_{4}\right)$ was the far upshore region of the beach beyond the furthest point of wave movement. WETM: wave energy transmitting membrane. 


\subsubsection{2: Comparison of high $(5.35 \mathrm{~N} / \mathrm{s})$ and low $(0.60 \mathrm{~N} / \mathrm{s})$ wave energy flux to evaluate partitioning of free-floating and floc-associated bacteria}

The beach was prepared as described in 2.2.3.1, and in two separate experiments the flume was run with 2 and $6 \mathrm{~cm}$ wave heights $(0.60$ and $5.35 \mathrm{~N} / \mathrm{s})$ to assess the effect of shear strength on the partitioning of free-floating and floc-associated bacteria in the water column. For each of these wave heights, the initial one-hour equilibration period was followed by $4 \mathrm{~h}$ of continuous wave activity followed by $2.5 \mathrm{~h}$ of no wave activity to investigate the influence of settling dynamics on the partitioning of bacteria. Samples were collected as in 2.2.3.1, however an additional $50 \mathrm{~mL}$ water sample was collected for enumeration of free-floating and floc-associated fractions. In addition to the collection of plankton chambers, a CILAS 930 particle size analyzer was used to measure median equivalent spherical diameter $\left(\mathrm{d}_{50}\right)$ in real time. This system was used to perform particle size analysis for particles ranging in size from 0.2 to $500 \mu \mathrm{m}$. In essence, this method involves passing the sample through a beam of laser light, with the scattered light being focused onto a detector. A particle size distribution is then calculated from the diffracted light data using an inversion algorithm.

\subsubsection{3: Transport of bacteria in uninoculated beach sand}

To assess the transport of bacteria through sand, the beach was formed using Ottawa sand. Eighty L of Hamilton Harbour water was mixed with $10^{9}$ cells (total cell count) of Pseudomonas sp. strain CTO7::gfp-2. The flume was left to stand for 24 hours. Sterile syringes were then used to core $6 \mathrm{~cm}$ into the sediment along transects 1-5 (Fig. 4). 


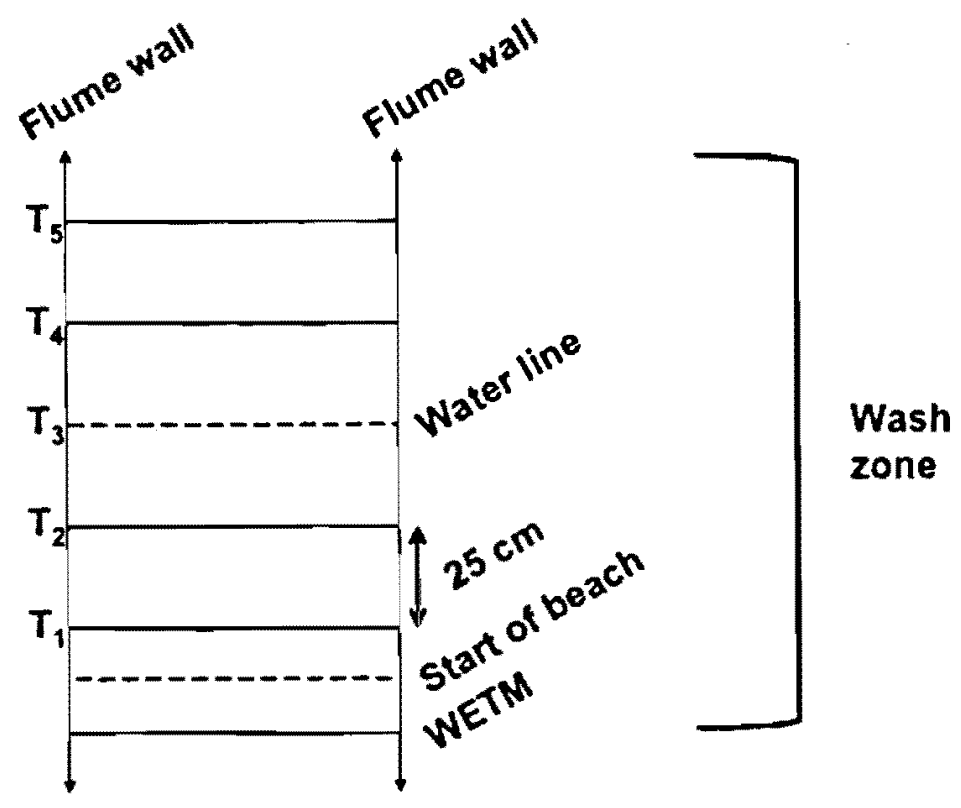

FIG. 4. Schematic of core sampling strategy used to study transport of the test strain in sand. Transects 1 and $2\left(T_{1}\right.$ and $\left.T_{2}\right)$ were below the water line. Transect $3\left(T_{3}\right)$ was at the water line, and transects 4 and $5\left(\mathrm{~T}_{4}\right.$ and $\left.\mathrm{T}_{5}\right)$ were above the water line. All transects were separated by a distance of approximately $25 \mathrm{~cm}$. Transects 4 and 5 were above the water table. WETM: wave energy transmitting membrane.

\subsection{4: Enumeration of test strain}

Serial dilution in $0.9 \%(\mathrm{~m} / \mathrm{v})$ sterile buffered saline and spread plating on $3 \mathrm{~g} / \mathrm{L}$ tryptic soy broth with $1.5 \%(\mathrm{~m} / \mathrm{v})$ agar was used for the routine enumeration of Pseudomonas sp. strain CTO7::gfp-2 in water and core samples. After incubation at $30^{\circ} \mathrm{C}$ for $24 \mathrm{~h}$, colonies were screened for gfp fluorescence using a fluorescence dissection microscope (Leica). Prior to creating serial dilutions, sand cores were sectioned into $2 \mathrm{~cm}$ aliquots. Bacteria were removed from sand grains by vortexing $1 \mathrm{~g}$ of sand with $0.5 \mathrm{~mL}$ of $0.9 \%(\mathrm{~m} / \mathrm{v})$ sterile buffered saline for 30 seconds (corresponded to approximately $80 \%$ 
cell removal (see 5.2)). To separate bacteria into free-floating and floc-associated fractions, $50 \mathrm{~mL}$ water samples were passed through a $5 \mu \mathrm{m}$ cellulose acetate filter (Sterlitech, Washington, United States) under slight vacuum. Cellulose acetate filters were chosen because they offered low binding of microorganisms (BSA protein binding of $3.8 \mu \mathrm{g} / \mathrm{cm}^{2}$ ). A previous study found that selective size filtration was useful for the estimation of particle-associated E. coli in river water (33). Droppo et al. (20) have also used low speed centrifugation for the fractionation of free-floating and floc-associated bacteria. There is currently no standard method for the analysis of sediment from freshwater systems, and it is understood that both selective size filtration and low speed centrifugation have their limitations. Bacteria in the filtrate were considered free-floating, while bacteria that remained on the filter were considered floc-associated. Both fractions were subjected to ultrasonication ( $35 \mathrm{kHz}$ ) for 1 minute (optimal time that maximized floc break up and minimized cell death; see 5.2). Samples were then diluted in $0.9 \%$ $(\mathrm{m} / \mathrm{v})$ sterile buffered saline, filtered through $0.45 \mu \mathrm{m}$ filters (Pall Corporation, Quebec, Canada), plated, and screened as described above. $\log _{10}$ transformations were applied to the bacterial count data to improve parametricity.

\subsection{5: Visualization of bacteria associated with sand grains and floc}

In order to assess biofilm development within sand grains, biofilms were cultivated in a continuous flow cell made from Plexiglas (dimensions of $30 \mathrm{~mm} \times 6 \mathrm{~mm}$ $\times 60 \mathrm{~mm}$ ). Sediment from Sunnyside Beach was placed in the flow cell, which was connected to a growth medium reservoir containing $1 \mathrm{~L}$ of Hamilton Harbour water supplemented with $0.3 \mathrm{~g} / \mathrm{L}$ tryptic soy broth, and waste collection flasks using silicone tubing to facilitate aeration (inner diameter $1.575 \mathrm{~mm}$ ). To prevent movement of sand 
grains into waste and medium reservoirs, small-pore mesh was glued at connection ports using commercially available silicon adhesive (SE 1124, General Electric) (Fig. 5). The flow cell was aseptically inoculated upstream using a sterile needle and syringe (VWR, Mississauga, Ontario, Canada) with $100 \mu \mathrm{L}$ of a culture of Pseudomonas sp. strain CTO7::gfp-2 that was previously cultured in a shaking incubator $(0.3 \mathrm{~g} / \mathrm{L}$ tryptic soy broth, $\left.30^{\circ} \mathrm{C}, 250 \mathrm{r} / \mathrm{min}\right)$. The inoculated bacteria were allowed to adhere for $0.5 \mathrm{~h}$ under quiescent conditions, whereafter a medium flow rate of $5 \mathrm{~mL} / \mathrm{h}$ was initiated. A WatsonMarlow 205S peristaltic pump supplied a continuous flow of growth medium through the sand matrix. Biofilms were left to develop for 72 hours, stained with $5 \mu$ M SYTO 9 nucleic acid stain (Cat. No. L7012, Invitrogen, Burlington, Ontario) for 15 minutes, flushed for 20 minutes with medium, and visualized using an LSM 510 confocal laser scanning microscope (CLSM) (Carl Zeiss, Ontario, Canada). Excitation of the fluorophore was achieved with a $488 \mathrm{~nm}$ Ar laser line (15\% output) and emission was captured with a band pass filter setting of 500-550 nm. 


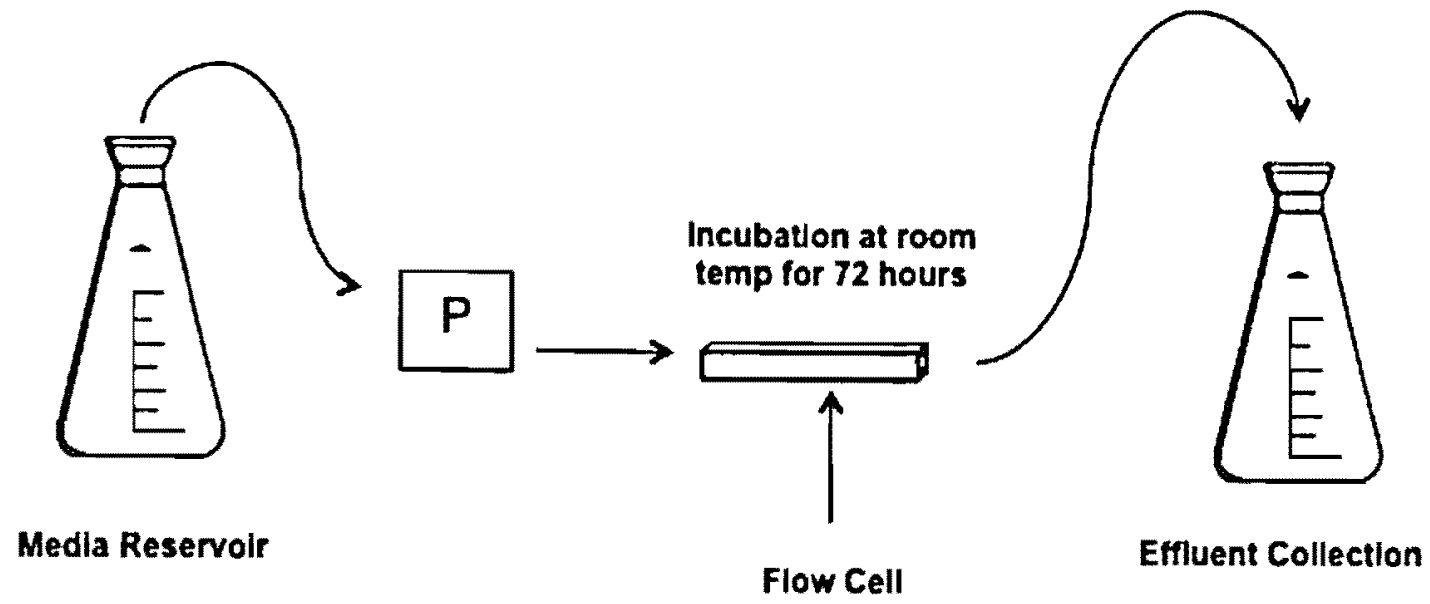

FIG. 5. Schematic diagram of an experimental continuous flow set-up. Medium (Hamilton Harbour water supplemented with $0.3 \mathrm{~g} / \mathrm{L}$ tryptic soy broth) was delivered through a peristaltic pump $(P)$ into a $30 \mathrm{~mm} \times 6 \mathrm{~mm} \times 60 \mathrm{~mm}$ flow cell fitted with small pore mesh on each end and incubated at room temperature for 72 hours.

To visualize the association of the test strain and indigenous bacteria with floc, plankton chambers containing floc were drained to remove Hamilton Harbour water. Approximately $1.5 \mathrm{~mL}$ of a $2 \%$ low melting point agarose solution (Gibco-BRL Life Technologies) was added to preserve floc shape and structure. Once stabilized, samples were stained with $5 \mu \mathrm{M}$ SYTO 9 nucleic acid stain for 15 minutes. The samples were washed three times every 15 minutes with $5 \mathrm{~mL}$ of phosphate buffered saline (EMD Chemicals, United States) to remove excess stain, and were then visualized using CLSM as described above. Unstained samples were visualized to determine the extent of floc auto-fluorescence. 


\subsection{6: Characterization of indigenous microbial community}

\subsubsection{1: DNA extractions}

Three $\mathrm{L}$ of Hamilton Harbour water was filtered through a $0.45 \mu \mathrm{M}$ filter. Using a sterile scoopula and forceps, the biomass was scraped from the filter and re-suspended in $0.5 \mathrm{~mL}$ of $1 \mathrm{x}$ sterile phosphate buffered saline. DNA was then extracted from the sample using the Ultraclean ${ }^{\mathrm{TM}}$ Soil DNA Isolation Kit (MO Bio Laboratories, California, USA).

To obtain DNA from Sunnyside Beach sand, 3 separate $1 \mathrm{~g}$ sand samples were extracted for DNA using the Ultraclean Soil DNA Isolation Kit. The eluate was then combined into one microcentrifuge tube and the final volume was brought down to $45 \mu \mathrm{L}$ under vacuum using a Savant DNA Speed Vac® DNA 110 (ThermoSavant, USA).

\subsubsection{2: PCR amplification of the bacterial 16S rRNA gene}

For PCR amplification of the 16S rRNA gene, the bacteria-specific forward primer U341F (5'-CCTACGGGAGGCAGCAG-3') and the reverse primer U758R (5'CTACCAGGGTATCTAATCC-3 ${ }^{*}$ ) were used. These primers are complementary to conserved regions of the $16 \mathrm{~S}$ rRNA gene, and were used to amplify a 418-bp fragment. The primers corresponded to positions 341 to 758 in the Escherichia coli sequence described by Muyzer et al, (60) and covered the variable regions V3 and V4. The 5 ' end of the forward primer contained a GC clamp (5'GGCGGGGCGGGGGCACGGGGGGCGCGGCGGGCGGGGCGGGGG-3'). Each $50 \mathrm{uL}$ PCR mixture contained $1 \mu \mathrm{L}$ of the template DNA (sand or water) $(\sim \operatorname{lng} / \mu \mathrm{L}), 25$ pmol of each oligonucleotide primer, $200 \mu \mathrm{M}$ of each dNTP, $1 \mathrm{mM} \mathrm{MgCl} 2$ and 2.5 units of Taq polymerase (Cat. No. 71003-3, EMD Chemicals, New Jersey, USA) in 10x Taq 
polymerase buffer (100 mM Tris- $\mathrm{HCl} \mathrm{pH} \mathrm{9.0,500} \mathrm{mM} \mathrm{KCl,} 15 \mathrm{mM} \mathrm{MgCl}_{2}$ ). After an initial temperature of $96^{\circ} \mathrm{C}$ for $5 \mathrm{~min}$ and thermocycling at $94^{\circ} \mathrm{C}$ for $1 \mathrm{~min}$, the annealing temperature was set to $65^{\circ} \mathrm{C}$ and was decreased by $1^{\circ} \mathrm{C}$ at every cycle for 10 cycles. Each cycle was followed by a 3 min elongation period at $72^{\circ} \mathrm{C}$. Twenty additional cycles were performed with annealing temperatures of $55^{\circ} \mathrm{C}(60)$. PCR products were loaded onto a $1 \%$ agarose gel along with a 100 -bp ladder (Cat. No. SM0241, Fermentas, Burlington, Ontario), stained with SYBR ${ }$ Safe DNA gel stain (Cat. No. S33102, Invitrogen, Burlington, Ontario), and imaged with a BioDoc-It imaging system (UVP, California, USA) to determine the presence, size, quality and quantity of PCR products (see 5.3).

\subsubsection{3: Denaturing gradient gel electrophoresis (DGGE)}

The 16S rRNA gene PCR products from four PCR reactions were combined for each sample and concentrated under vacuum in a Savant DNA Speed Vacß DNA 110 for DGGE analysis. About 400 ng of $16 \mathrm{~S}$ rRNA gene PCR product from each sample was loaded in each lane of an $8 \%$ polyacryalmide gel containing gradients of $35-65 \%$ denaturant ( $7 \mathrm{M}$ urea and $40 \%$ deionized formamide were considered to be $100 \%$ denaturant). DGGE was performed with a DCode ${ }^{\text {TM }}$ Universal Mutation Detection System (Bio-Rad). Electrophoresis was run at a constant voltage of $80 \mathrm{~V}$ for $16 \mathrm{~h}$ at $60^{\circ} \mathrm{C}$ in $1 \mathrm{x}$ TAE running buffer. The gels were then stained with 1:25000 SYBR ${ }^{\circledR}$ Gold Nucleic Acid Gel Stain (Cat. No. S11494, Invitrogen, Burlington, Ontario) and imaged with a Gel Logic 1500 Imaging System using Kodak Molecular Imaging Software Version 4.0 (Marketlink Scientific, Burlington, Ontario), which had been fitted with a Safe Imager ${ }^{\mathrm{TM}}$ 2.0 Blue Light Transilluminator (Invitrogen, Burlington, Ontario). 


\section{3: RESULTS AND DISCUSSION}

2.3.1: Validation of the use of Pseudomonas sp. strain CTO7::gfp-2 as a tracer organism

The association of indigenous water and sand bacteria and the test strain (Pseudomonas sp. strain CTO7::gfp-2) with floc material can be seen in Fig. 6b. In order to express GFP, the test strain required a suitable carbon source, which was provided by 3 $\mathrm{g} / \mathrm{L}$ tryptic soy broth with $1.5 \%(\mathrm{~m} / \mathrm{v})$ agar. Fig. 6a shows unstained floc material and the absence of auto-fluorescence among members of the indigenous microbial community when examined with a band pass filter at $500-550 \mathrm{~nm}$. The lack of auto-fluorescence among indigenous community members was also verified by screening replicate TSA plates of Hamilton Harbour water and Sunnyside Beach sand with a dissection microscope. The microbial load of Sunnyside Beach sand and Hamilton Harbour water was $10^{2} \mathrm{CFU} / \mathrm{g}$ (wet weight) and $10^{2} \mathrm{CFU} / \mathrm{mL}$, respectively, and therefore the indigenous community was lost during dilution of samples since most plates were countable at the $10^{3}$ and $10^{4}$ dilutions. 


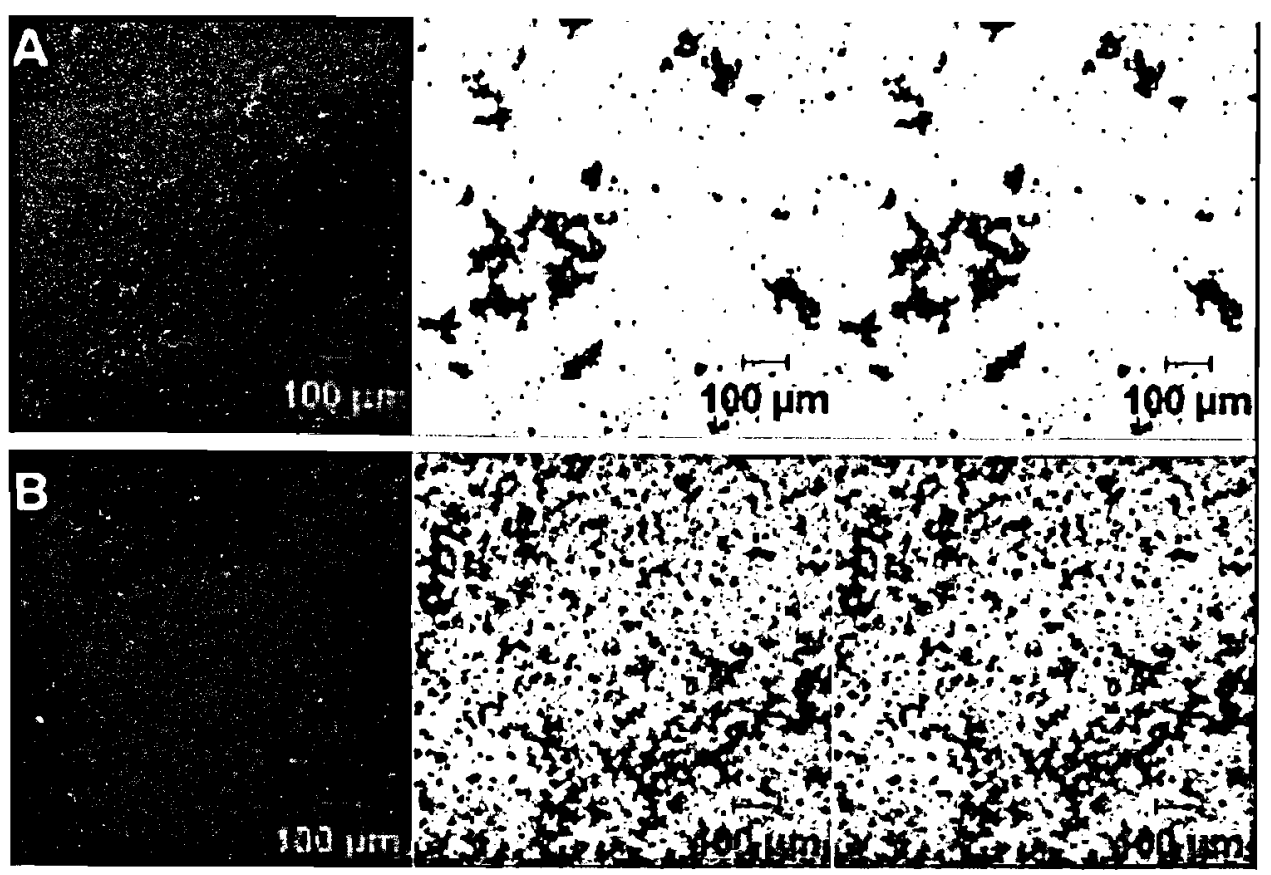

FIG. 6. CLSM image of unstained (A) and stained (SYTO 9 nucleic acid stain) (B) floc material showing association with indigenous microbial community and GFP-labelled bacteria.

Fingerprints of dominant members of the indigenous microbial community found in Sunnyside Beach sand and Hamilton Harbour water can be observed in Fig. 7. The level of diversity (number of bands shown) in the denaturing gradient gel electrophoresis profile is similar to studies examining free-floating and particle-associated bacteria in river water (34). 


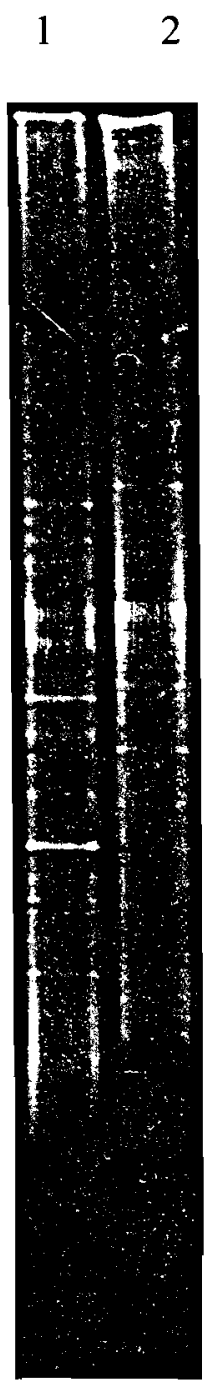

FIG. 7. Denaturing gradient gel electrophoresis banding patterns of Sunnyside Beach sand (1) and Hamilton Harbour water (2) bacterial 16S rRNA gene fragments

\subsection{2: Movement of bacteria through sand}

The test strain was found to be present throughout the entire flume beach within 24 hours of adding Hamilton Harbour water containing Pseudomonas sp. strain CTO7::gfp-2. The highest concentration of bacteria was found at the water line (shoreline), while the presence of bacteria along transects 4 and 5, which both lay above 
the water line and water table, indicated that cells moved along a wet to dry gradient potentially by capillary action (Fig. 8). The distribution of cells within the top, middle and bottom $2 \mathrm{~cm}$ of the sediment bed was highly variable for all transects.

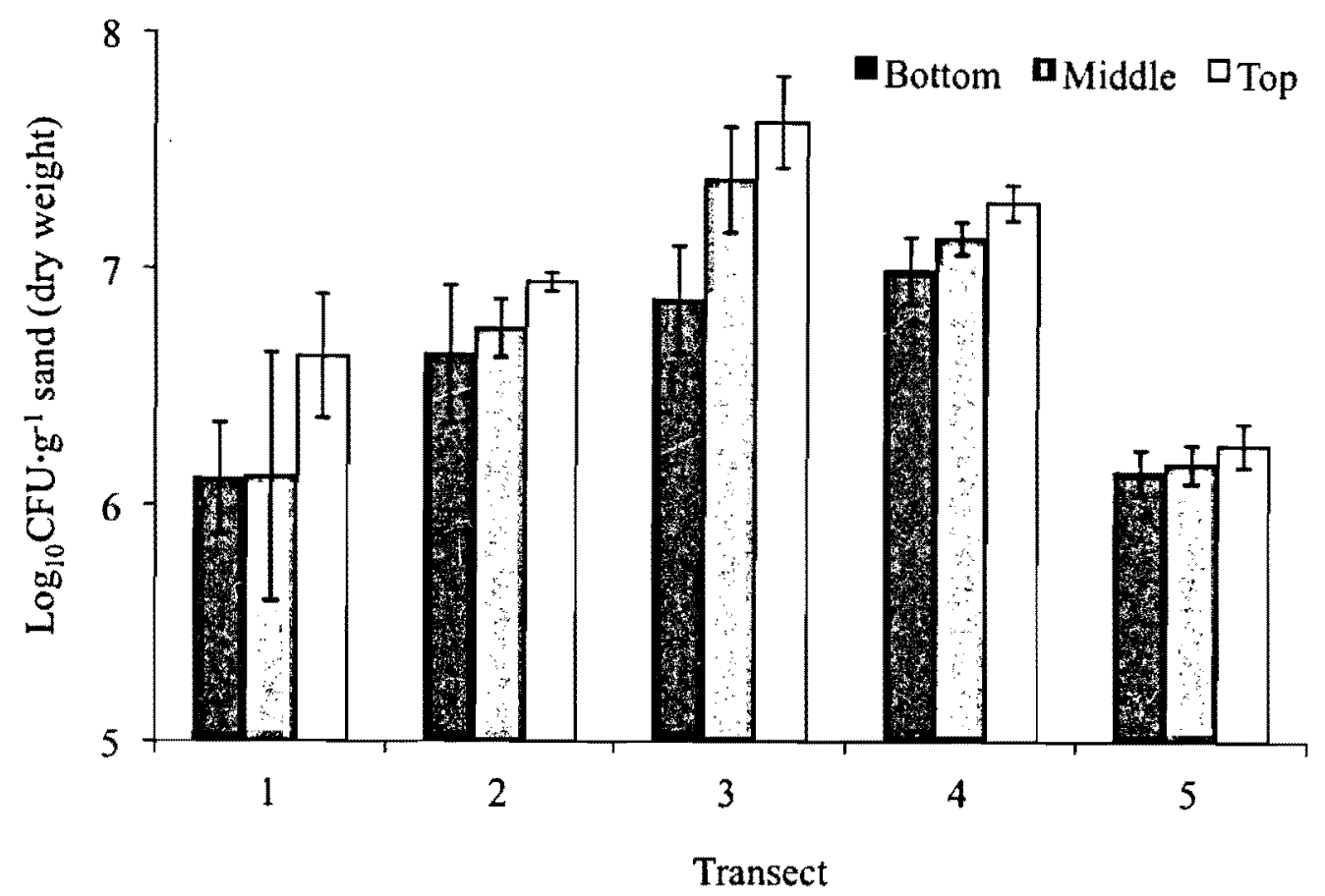

FIG. 8. Tracking the movement of Pseudomonas sp. strain CTO7::gfp-2 with sand cores taken along five beach transects. Transects 1 and 2 were below the water line. Transect 3 was at the water line, and transects 4 and 5 were above the water line and water table. All transects were separated by a distance of approximately $25 \mathrm{~cm}$.

Field studies $(9,37)$ have shown high variability of bacterial indicator densities in sand samples, but observed that the highest beach counts were found in dry sand. Dry sand may harvest more pathogens than wet sand because wet sand is more susceptible to predation and losses due to wave action. As shown in the flume, the ability of the test strain to move beyond the shoreline combined with studies $(1,52)$ that show the 
persistence and/or growth of fecal indicators and pathogens in beach sand emphasizes the need to examine entire beach environments when determining beach closures rather than solely assessing water quality.

\subsection{3: Water and sediment chemical and nutrient analysis}

In order to assess the potential for nutrient loading after wave action, water chemistry and nutrient analysis was performed. In two experiments examining the cumulative effect of increasing wave energy on bacterial loading (reported as trial 1 and 2 in tables 1 and 2), water and sediment were sampled from the swash and upshore zones. The concentration of calcium, magnesium, potassium, and sulphate ions, dissolved organic carbon (DOC) and dissolved inorganic carbon (DIC) increased in water after three hours of wave action (Table 1). The DOC concentration (3.9 to $4.8 \mathrm{mg} / \mathrm{L}$ ) fell within the range ( 1.8 to $5.0 \mathrm{mg} / \mathrm{L}$ ) reported for other freshwater lakes located in south central Ontario, County of Haliburton, and the District of Muskoka. The DIC concentration $(23.4$ to $28.6 \mathrm{mg} / \mathrm{L})$ fell outside of the range $(1.91$ to $12.4 \mathrm{mg} / \mathrm{L})$ reported for these lakes (17). After wave action the concentration of inorganic and organic carbon was higher in sediment sampled upshore than in sediment sampled from the dynamic swash zone for trial 1 (Table 2). In trial 2, the concentration of organic carbon was higher $(2.26 \%)$ in swash zone sediment than in sediment sampled upshore $(1.73 \%)$. The organic content in Sunnyside Beach sand was higher than that reported for shoreline sand at Conger Lighthouse Beach, Lake Huron (0.09\%) (1). 
TABLE 1. Chemical analysis of Hamilton Harbour water prior to and following exposure to 2,4 , and $6 \mathrm{~cm}$ waves, each for one hour.

\begin{tabular}{cccccccccccc}
\hline & & \multicolumn{10}{c}{ Nutrient Concentration (mg/L) } \\
\cline { 3 - 12 } & Condition & $\mathrm{Ca}^{2+}$ & $\mathrm{Mg}^{2+}$ & $\mathrm{Na}^{+}$ & $\mathrm{K}^{+}$ & $\mathrm{F}^{-}$ & $\mathrm{Cl}^{-}$ & $\mathrm{SO}_{4}{ }^{2-}$ & $\mathrm{SRP}$ & $\mathrm{DIC}$ & $\mathrm{DOC}$ \\
\hline 1 & $\mathrm{BW}$ & 45.6 & 12.1 & 42.6 & 4.07 & 0.30 & 69.3 & 44.2 & 0.0167 & 24.3 & 3.9 \\
& $\mathrm{AW}$ & 49.2 & 12.6 & 41.9 & 4.37 & 0.28 & 69.0 & 46.6 & 0.0027 & 26.8 & 4.6 \\
2 & $\mathrm{BW}$ & 47.0 & 12.7 & 44.8 & 4.30 & 0.33 & 76.2 & 46.0 & 0.0208 & 23.4 & 3.9 \\
& $\mathrm{AW}$ & 51.7 & 13.3 & 44.2 & 4.88 & 0.30 & 73.0 & 48.0 & 0.0034 & 28.6 & 4.8 \\
\hline
\end{tabular}

BW: Sample taken before waves

AW: Sample taken after 3 hours of waves $(2,4,6 \mathrm{~cm}$ each for one hour)

SRP: Soluble reactive phosphorus

DIC: Dissolved inorganic carbon

DOC: Dissolved organic carbon

TABLE 2. Nutrient analysis for upshore and swash zone Sunnyside Beach sediment after running 2,4 , and $6 \mathrm{~cm}$ waves, each for one hour.

\begin{tabular}{|c|c|c|c|c|}
\hline \multirow[b]{2}{*}{ Trial } & \multirow[b]{2}{*}{ Sediment Source } & \multicolumn{3}{|c|}{ Nutrient Concentration (\%) } \\
\hline & & $\begin{array}{c}\mathrm{C} \\
\text { (inorganic) }\end{array}$ & $\begin{array}{c}\mathrm{C} \\
\text { (organic) }\end{array}$ & $\begin{array}{c}\mathrm{N} \\
\text { (organic) }\end{array}$ \\
\hline \multirow[t]{2}{*}{1} & Upshore & 2.26 & 2.37 & 0 \\
\hline & Swash & 1.12 & 1.93 & 0.02 \\
\hline \multirow[t]{2}{*}{2} & Upshore & 1.18 & 1.73 & 0 \\
\hline & Swash & 0.94 & 2.26 & 0 \\
\hline
\end{tabular}

The increased DIC and DOC concentrations in water after wave action may be reflective of sediment erosion since lower concentrations were observed for inorganic 
carbon in swash sediment. Although the concentration of Pseudomonas sp. strain CTO7::gfp-2 did not increase in batch experiments using Hamilton Harbour water after 8 hours in a shaking incubator (see 5.1), nutrient loading may have implications for the growth and/or persistence of pathogens present in the water column or those which are re-suspended from the sediment bed due to wave action. A study by Droppo et al. (22) showed that counts of $E$. coli and Salmonella were elevated within suspended sediment relative to the sediment bed in river water from Ottawa, Canada. Given that it is possible that a single mouthful of water contaminated with $E$. coli $\mathrm{O} 157: \mathrm{H} 7$ can cause illness (14), nutrient loading may have implications for the health of bathers who swallow contaminated water.

It is important to note that the growth and decay kinetics of bacteria and pathogens involves more than just nutrient availability. Other variables include temperature, UV radiation, insolation, predation by higher-order organisms, incubation procedure (batch, diffusion chamber, or field) and type of bacteria (pure strain versus population from the environment $)(8,10,84,92)$. Nevertheless, nutrient loading of water imparted by wave action may contribute to the persistence and/or growth of pathogens in water.

\subsection{4: Effect of increasing shear on bacterial loading in water}

Flume experiments examining the rc-suspension of bacteria from the sediment bed showed that increasing wave energy flux increased the number of Pseudomonas sp. strain CTO7::gfp-2 in the water column when waves were sequentially generated at wave energy fluxes of $0.60,2.38$ and $5.35 \mathrm{~N} / \mathrm{s}$ (Fig. 9a). The concentration of the test strain

ranged from $5.18 \log 10 \pm 0.05 \log 10$ with no waves to $5.89 \log 10 \pm 0.13 \log 10$ at a wave 
energy flux of $5.35 \mathrm{~N} / \mathrm{s}$. As expected, the total suspended solids concentration also increased from approximately $9.78 \mathrm{mg} / \mathrm{L} \pm 0.15 \mathrm{mg} / \mathrm{L}$ with no waves to $187.00 \mathrm{mg} / \mathrm{L} \pm$ $0.67 \mathrm{mg} / \mathrm{L}$ at a wave energy flux of $5.35 \mathrm{~N} / \mathrm{s}$. Similar trends in the concentration of the test strain and total suspended solids were observed for trials 2 to 4 (Fig.9b,c,d). The median equivalent spherical diameter $\left(\mathrm{d}_{50}\right)$ of flocs in suspension ranged from $5.91 \mu \mathrm{m}$ with no waves to $45.1 \mu \mathrm{m}$ at a wave energy flux of $2.38 \mathrm{~N} / \mathrm{s}$ for trial 1 . The overall increase in floc size may have been due to flocculation in the water column, and/or the re-suspension of larger particles with increasing wave energy. For trials 1 and 4 the $d_{50}$ decreased at the highest wave energy flux, which may be reflective of higher turbulence. The breaking of flocs at high wave energy may also be attributed to the composition of the sediment, as it was collected during different times of the year and thus may have varied in the composition of the cohesive fraction (silts and clays). The formation of larger flocs may have significance for the partitioning of free-floating and floc-associated bacteria and their subsequent transport (see 2.3.5). 
A

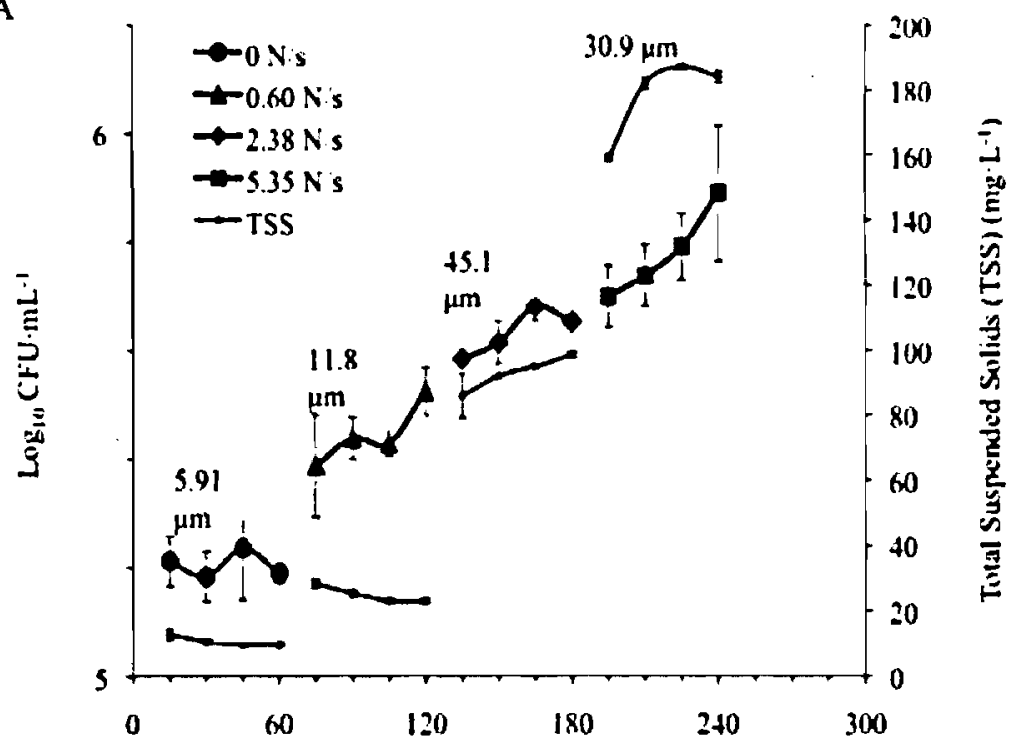

B

C

Time (minules)

D
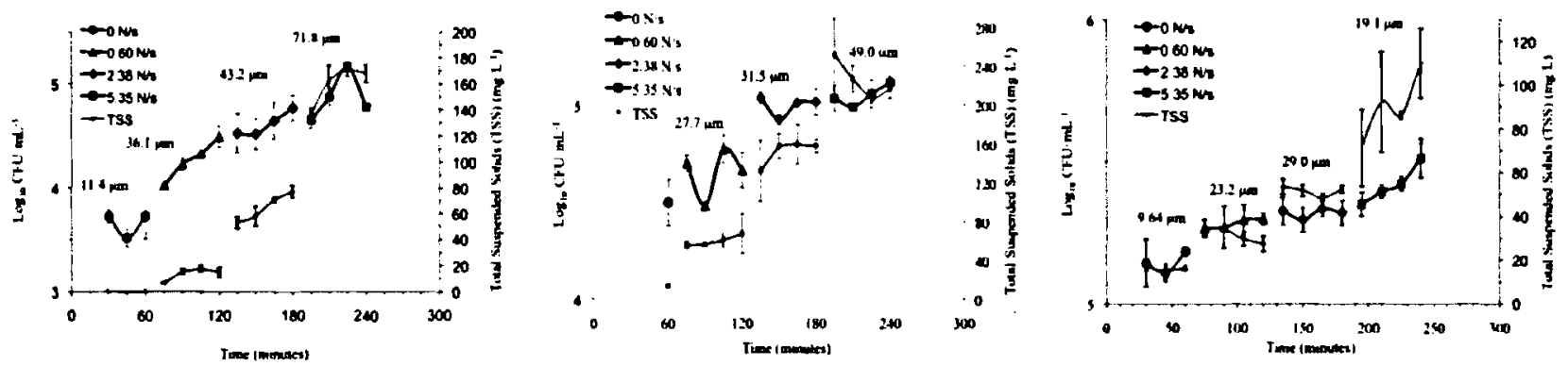

FIG. 9. Cumulative effect of increasing wave energy flux on total suspended solids (TSS) and levels of Pseudomonas sp. strain CTO7::gfp-2 in water. A, B, C, D represent trials 1 to 4 , respectively. The $\mathrm{d}_{50}$ value for each wave energy flux is reported above the solid black line. Counts of test strain and total suspended solids represent average values ( $n=3$ and $n=2$, respectively).

These results suggest that beach water samples collected at times with little to no wave action may underestimate the human pathogen health risk. Once re-suspended, bacteria may become further mobilized by general water flow and wind waves, leading to an increased potential for human ingestion (23). The re-suspension of bacteria imparted 
by wave action together with the delay imparted by current methods used for sample analysis pose a challenge for public health units. Predictive models may therefore be an appropriate method for assessing the human pathogen health risk during times of turbulence and in storm events. A field study by Kinzelman et al. (48) found wave height to be the best predictor of $E$. coli concentration at beaches, and were able to derive a formula to predict current day $E$. coli count. The demonstrated quantifiable relationship between wave action and re-suspension of viable bacteria deposited in sediments is significant because it compliments field studies $(37,57,90)$ that have listed wave action as a potential mechanism of bacterial loading in surface water and addresses the need to examine the influence of shear forces on bacterial transport in freshwater systems (99).

A positive correlation $\left(\mathrm{R}^{2}=0.87\right)$ was obtained for trial 1 when the concentration of bacteria in the water column was plotted as a function of total suspended solids concentration (Fig. 10). Trials 2 to 4 also showed a positive correlation greater than or equal to 0.80 . This supports an earlier suggestion that turbidity might be indicative of the microbiological quality of water $(20,32)$. Using samples collected from water and lakebottom sediments along with additional environmental data, Francy and Darner (32) found that turbidity, antecedent rainfall, volumes of wastewater-treatment plant overflows and metered outfalls, and wave height were statistically related to levels of Escherichia coli at three public bathing beaches along Lake Erie. However, Kinzelman et al. (48) found that turbidity was not predictive of $E$. coli levels, suggesting that the specific environment (local phenomenon) may influence the predictive capabilities of the relationship demonstrated in this study. Overlapping environmental variables such as 
temperature fluctuations, grazing pressure, nutrient availability, and decay kinetics may affect the concentration of bacteria in suspension.

A
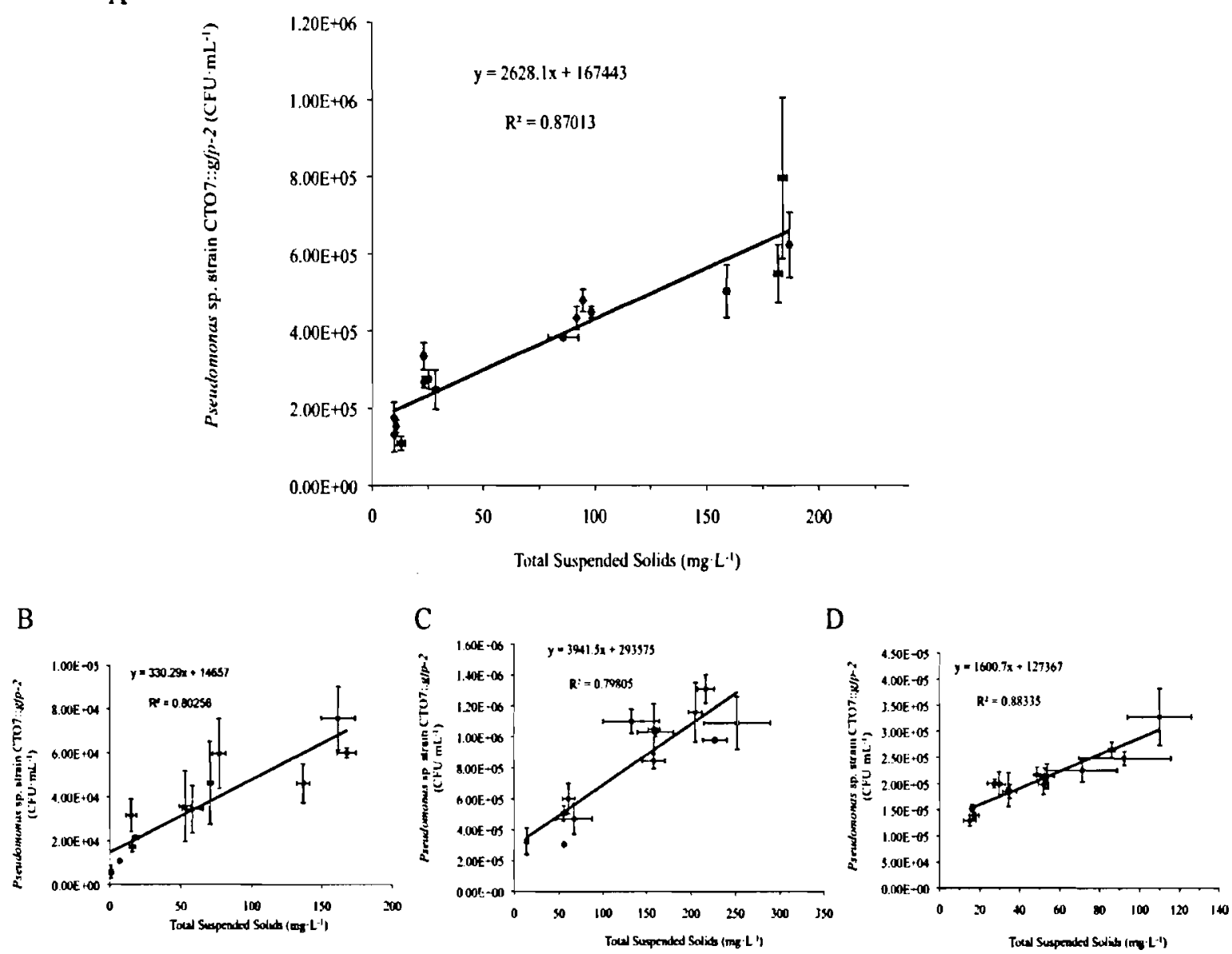

FIG. 10. Correlation between total suspended solids and Pseudomonas sp. strain CTO7::gfp-2 in water. A, B, C, D represent trials 1 to 4 , respectively

Fig. 11 shows a CLSM image of a 72-hour sand biofilm composed of Pseudomonas sp. strain CTO7::gfp-2 and indigenous bacteria, which was formed under continuous flow conditions. Growth was observed in the interstitial voids of the grains.

Sand grains provide a large surface area for the growth of microorganisms and the cracks and crevices on and between grains provide microniches for microbial growth, enhanced 
survival, and/or protection from predation $(9,37)$. Sand grains are too large to be resuspended at the energy regimes studied here, however the cohesive fraction (clays, silts, and organic matter) associated with the grains may be re-suspended and subsequently transport floc-associated and planktonic bacteria. It is also probable that sand biofilms will form loosely associated micro-colonies that will be removed with increased shear, a phenomenon known as sloughing (81).

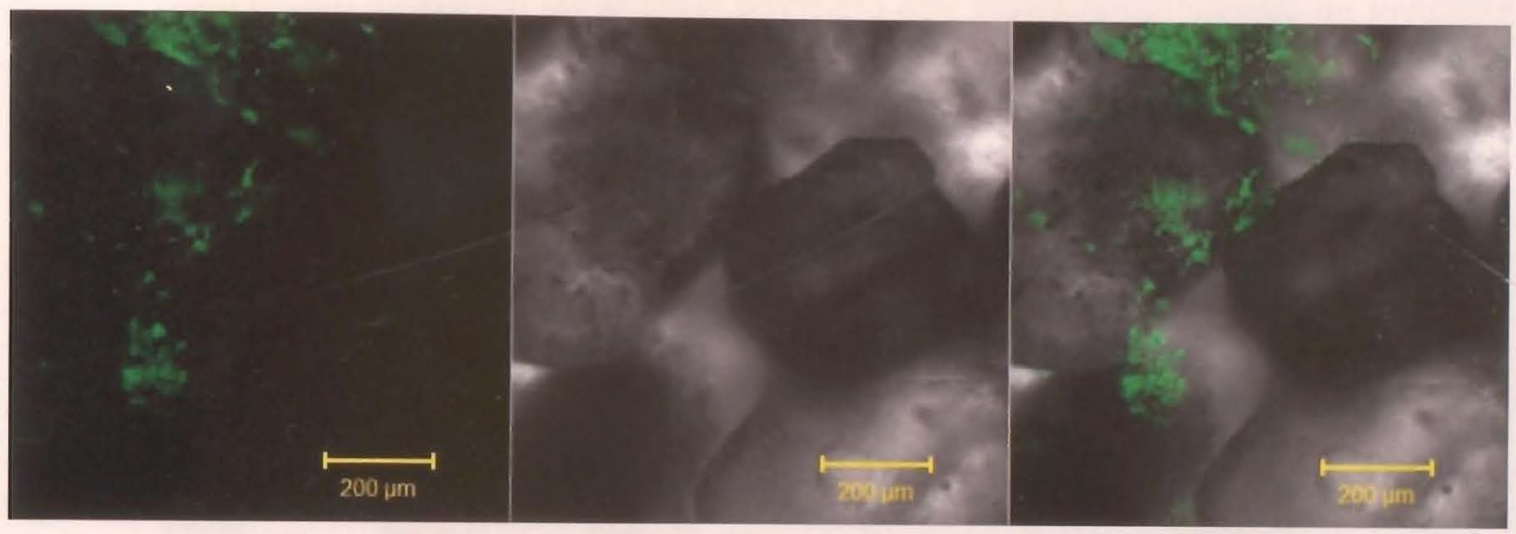

FIG. 11 CLSM image of a 72 hour sand biofilm formed in interstitial voids. Biofilm contains both indigenous bacteria and Pseudomonas sp. strain CTO7::gfp-2.

The erosion of Pseudomonas sp. strain CTO7::gfp-2 from the sediment bed was seen along three out of four beach transects (Fig. 12). Graphs of transects corresponding to the wave breaking zone, swash zone, and air-water-sediment interfacial zone show that increasing wave energy flux led to the loss of the test organism from the bed sediment (Fig. 12a,b,d). This effect was most prominent for the top core section (corresponding to the top $2 \mathrm{~cm}$ of the sediment bed), which correlates with visual observations that confirm this section as the most dynamic. The transect that corresponded to the far upshore region of the beach (Fig. 12c) did not come into contact with the water table or swash and consequently did not have erosion of Pseudomonas sp. strain CTO7::gfp-2. The bottom 
section of this core did however show a decrease in the numbers of test organism during wave events, suggesting that cells were being drawn from this area of the beach as backwash moved down the shoreline. Several field studies have listed wave action as a mechanism of bacterial loading of foreshore sands $(41,93)$. It was therefore expected that this phenomenon would be most pronounced at the air-water-sediment interfacial zone (Fig. 12d), since samples were taken at the furthest point that swash ran up the beach; however no concentration effect was observed. This could have been due to the limitations of the flume in simulating longshore drift, a sediment transport process that moves sand grains along the shoreline in a zigzag pattern. Longshore currents studied in the surf zone of marine environments have been shown to deliver contaminated river water up to $5 \mathrm{~km}(47)$. 
A. Transect 1

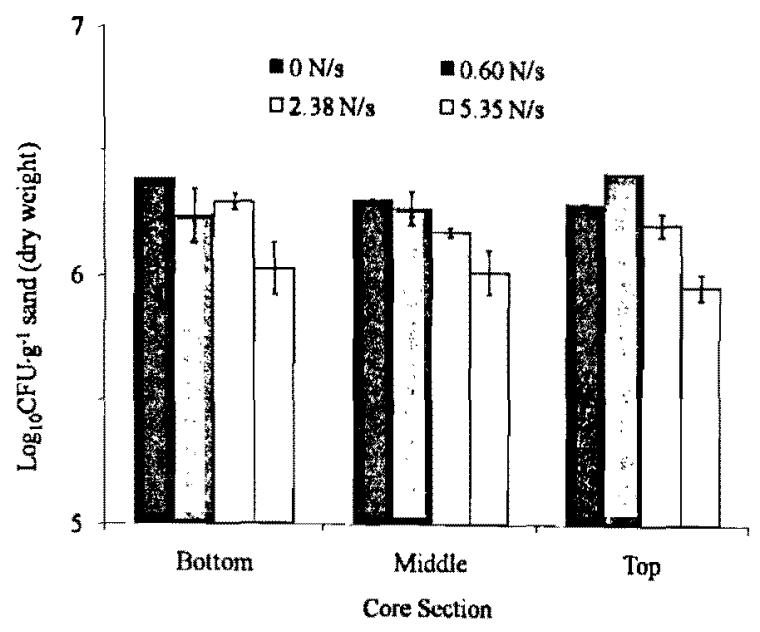

C. Transect 4

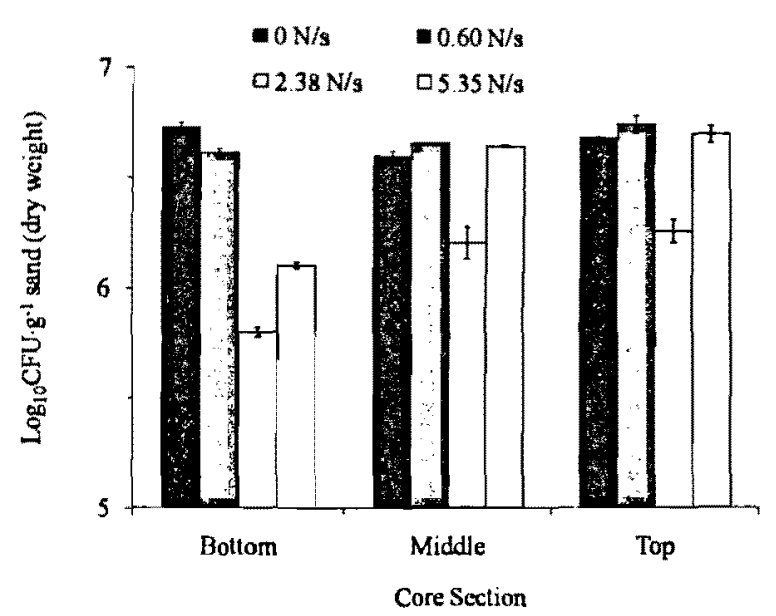

B. Transect 2

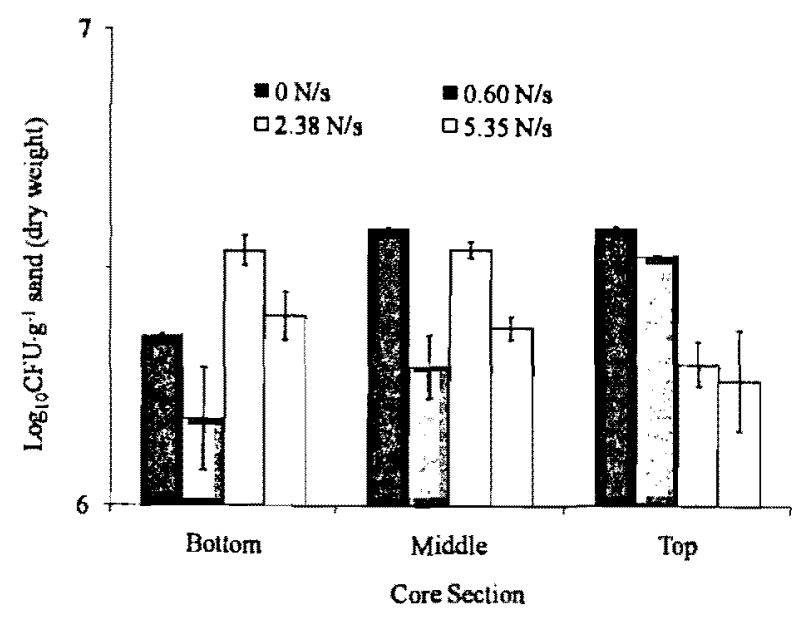

D. Transect 3

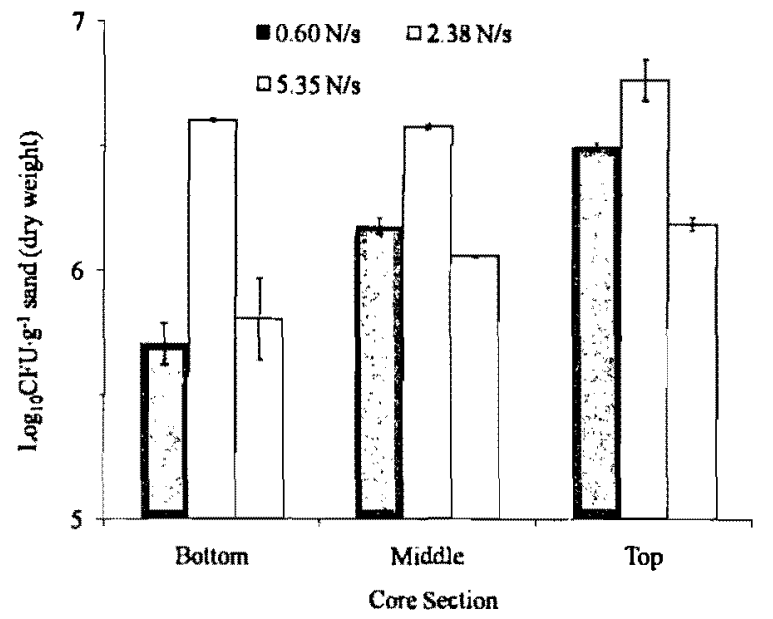

FIG. 12. Enumeration of Pseudomonas sp. strain CTO7::gfp-2 from sand cores taken along four beach transects (trial 1). A) Transect $1\left(T_{1}\right)$ refers to below water line, and was roughly the wave breaking zone. $B)$ Transect $2\left(T_{2}\right)$ refers to the swash zone, which was the area where the shoreline moves back and forth as waves meet the shore. C) Transect 4 was the far upshore region of the beach beyond the furthest point of wave movement. D) Transect $3\left(\mathrm{~T}_{3}\right)$ characterized the air-water-sediment interface, and was the furthest area where water travelled up the beach when waves were run. The exact location of transect 3 
varied with wave energy, as higher wave energies pushed water further up the beach.

Bottom and top refer to the enumeration of the test organism from $6 \mathrm{~cm}$ and $2 \mathrm{~cm}$ below the surface of the sediment bed. Counts of the test organism represent average $(n=2)$. For trials 2 to 4 see 5.4 .

Field studies have demonstrated the growth and/or persistence of indicator $E$. coli and enterococci in beach sand and sediments $(1,2,8,9,37,41,52,57,90-92,94,99)$, highlighting the importance in studying entire beach environments when assessing public health risk. Given the ability of sand to harbour microorganisms it is surprising to find that some areas, such as South Florida, do not monitor sand from the surf zone and upper beach area (9). Indeed, it has been shown that shoreline water quality may not be reflective of regional water quality $(57,76)$, and that foreshore and submerged sand can harbour higher concentrations of indicator organisms than what is found in beach water (90). Monitoring programs in the United States generally rely on one sample collected at the shoreline (76), while federal guidelines in Canada suggest that sediment samples should be collected when there is evidence that bathing beaches could be the source of waterborne disease (29). Amending these guidelines to include a sampling regime that involves the routine examination of sedimentary components, shoreline and near shore water, and regions upshore of the beach could be an effective strategy for assessing the health risk at public beaches.

\subsection{5: Comparison of low $(0.60 \mathrm{~N} / \mathrm{s})$ and high $(5.35 \mathrm{~N} / \mathrm{s})$ wave energy flux on the partitioning of free-floating and floc-associated bacteria}

When water samples were partitioned into free-floating and floc-associated fractions using selective size filtration, it was found that the viable cell count did not 
change significantly during the 4 hours of wave activity at $0.60 \mathrm{~N} / \mathrm{s}$ (Table 3 ). When waves were turned off however, there was an order of magnitude increase in the number of floc-associated cells per mg of floc material. Even though the suspended sediment concentration was reduced by less than half from time 300 (wave activity) to time 330 minutes (no wave activity), there was an order of magnitude increase in the number of floc-associated cells when counts were normalized per mg of floc. The median equivalent spherical diameter decreased from $17 \mu \mathrm{m}$ to $5 \mu \mathrm{m}$ during wave activity, and further decreased to $2.6 \mu \mathrm{m}$ after 2.5 hours of no wave activity. This indicated that larger flocs were settling out of the water column under mild turbulence. 
TABLE 3. Partitioning of free-floating and floc-associated cells before, during and after operating flume at $0.60 \mathrm{~N} / \mathrm{s}$.

\begin{tabular}{|c|c|c|c|c|c|c|}
\hline $\begin{array}{c}\text { Wave } \\
\text { Energy } \\
\text { Flux } \\
(\mathrm{N} / \mathrm{s})\end{array}$ & $\begin{array}{l}\text { Time } \\
(\mathrm{min})\end{array}$ & $\begin{array}{c}\text { Median } \\
\text { Floc ESD } \\
\text { at } 50 \% \\
(\mu \mathrm{m})\end{array}$ & $\begin{array}{c}\text { Total } \\
\text { Suspended } \\
\text { Solids } \\
(\mathrm{mg} / \mathrm{L})\end{array}$ & $\begin{array}{c}\text { Free- } \\
\text { Floating } \\
\text { Cells/ } 50 \\
\mathrm{~mL}\end{array}$ & $\begin{array}{c}\text { Floc- } \\
\text { Associated } \\
\text { Cells/ } 50 \\
\mathrm{~mL}\end{array}$ & $\begin{array}{c}\text { Floc- } \\
\text { Associated } \\
\text { Cells } \\
\text { (CFU/ mg } \\
\text { floc) }\end{array}$ \\
\hline 0 & 30 & nd & $10 \pm 1$ & $6.20 \times 10^{2}$ & $1.29 \times 10^{4}$ & $2.58 \times 10^{4}$ \\
\hline 0 & 60 & 14.75 & $13 \pm 2$ & $1.35 \times 10^{3}$ & $1.02 \times 10^{4}$ & $1.57 \times 10^{4}$ \\
\hline 0.60 & 90 & 17.07 & $56 \pm 2$ & $4.30 \times 10^{3}$ & $2.71 \times 10^{5}$ & $9.68 \times 10^{4}$ \\
\hline 0.60 & 120 & 15.09 & $67 \pm 1$ & $3.80 \times 10^{3}$ & $5.40 \times 10^{4}$ & $1.61 \times 10^{4}$ \\
\hline 0.60 & 150 & 13.56 & $61 \pm 2$ & $1.80 \times 10^{3}$ & $8.10 \times 10^{4}$ & $2.66 \times 10^{4}$ \\
\hline 0.60 & 180 & 12.42 & $56 \pm 1$ & $2.10 \times 10^{3}$ & $5.50 \times 10^{4}$ & $1.96 \times 10^{4}$ \\
\hline 0.60 & 210 & 11.33 & $55 \pm 2$ & $2.40 \times 10^{3}$ & $7.80 \times 10^{4}$ & $2.84 \times 10^{4}$ \\
\hline 0.60 & 240 & 8.56 & $44 \pm 2$ & $1.90 \times 10^{3}$ & $9.30 \times 10^{4}$ & $4.23 \times 10^{4}$ \\
\hline 0.60 & 270 & 7.93 & $36 \pm 1$ & $3.50 \times 10^{3}$ & $9.00 \times 10^{4}$ & $5.00 \times 10^{4}$ \\
\hline 0.60 & 300 & 5.36 & $20 \pm 1$ & $2.40 \times 10^{3}$ & $6.60 \times 10^{4}$ & $6.60 \times 10^{4}$ \\
\hline 0 & 330 & 4.63 & $16 \pm 2$ & $1.50 \times 10^{3}$ & $1.14 \times 10^{5}$ & $1.43 \times 10^{5}$ \\
\hline 0 & 360 & 3.24 & $8 \pm 1$ & $2.00 \times 10^{3}$ & $1.51 \times 10^{5}$ & $3.78 \times 10^{5}$ \\
\hline 0 & 390 & 3.05 & $16 \pm 9$ & $1.20 \times 10^{3}$ & $5.90 \times 10^{4}$ & $7.38 \times 10^{4}$ \\
\hline 0 & 420 & 3.11 & $23 \pm 4$ & $6.90 \times 10^{3}$ & $2.28 \times 10^{5}$ & $1.98 \times 10^{5}$ \\
\hline 0 & 450 & 2.66 & $21 \pm 7$ & $3.80 \times 10^{3}$ & $1.31 \times 10^{5}$ & $1.25 \times 10^{5}$ \\
\hline
\end{tabular}

ESD: equivalent spherical diameter $\mathrm{n}=2$ for total suspended solids nd: no data 
Similar to what was observed for a wave energy flux of $0.60 \mathrm{~N} / \mathrm{s}$, the viable freefloating and floc-associated cell counts did not vary significantly during the 4 hours of wave activity at $5.35 \mathrm{~N} / \mathrm{s}$ (Table 4). The median floc equivalent spherical diameter remained consistent throughout the 4 hours of wave activity, and decreased only slightly when waves were shut off (time 330 to time 450 minutes). Bacteria that are attached to larger flocs may be removed by the downward flux of larger particles. A study by GarciaArmisen and Servais (33) estimated the settling rate of particle-associated E. coli and found that free $E$. coli did not settle in laboratory mesocosm experiments. This trend was observed in the free-floating data when waves were shut off. The sedimentation of larger flocs under low energy conditions thus highlights the importance of sampling both the sediment and overlying water column. It is likely that higher wave energy flux prevented larger flocs from settling to the sediment bed. The total suspended solids concentration decreased by roughly half when waves were shut off, and the number of floc-associated cells per mg of floc material also increased by an order of magnitude. The total cell count (free-floating and floc-associated) and total suspended solids concentration for low $(0.60$ $\mathrm{N} / \mathrm{s})$ and high $(5.35 \mathrm{~N} / \mathrm{s})$ wave energy flux is shown in Fig. 13. The total cell count remained consistent during wave activity in both scenarios and then decreased when turbulence was removed from the system, potentially due to the downward flux of larger particles. Alternatively, the lower number of cells observed during quiescent conditions could be due to the sample analysis procedure, as samples collected for the determination of total cell count were not sonicated. 
TABLE 4. Partitioning of free-floating and floc-associated cells before, during and after operating flume at $5.35 \mathrm{~N} / \mathrm{s}$.

\begin{tabular}{|c|c|c|c|c|c|c|}
\hline $\begin{array}{l}\text { Wave } \\
\text { Energy } \\
\text { Flux } \\
(\mathrm{N} / \mathrm{s})\end{array}$ & $\begin{array}{l}\text { Time } \\
\text { (min) }\end{array}$ & $\begin{array}{c}\text { Median } \\
\text { Floc ESD } \\
\text { at } 50 \% \\
(\mu \mathrm{m})\end{array}$ & $\begin{array}{c}\text { Total } \\
\text { Suspended } \\
\text { Solids } \\
(\mathrm{mg} / \mathrm{L})\end{array}$ & $\begin{array}{c}\text { Free- } \\
\text { Floating } \\
\text { Cells / } 50 \\
\mathrm{~mL}\end{array}$ & $\begin{array}{c}\text { Floc- } \\
\text { Associated } \\
\text { Cells } / 50 \\
\mathrm{~mL}\end{array}$ & $\begin{array}{c}\text { Floc- } \\
\text { Associated } \\
\text { Cells } \\
\text { (CFU/ mg } \\
\text { floc) }\end{array}$ \\
\hline 0 & 30 & nd & $\overline{2 \pm 1}$ & $7.70 \times 10^{1}$ & $2.70 \times 10^{3}$ & $2.70 \times 10^{4}$ \\
\hline 0 & 60 & 15.19 & $2 \pm 1$ & $2.30 \times 10^{1}$ & $3.60 \times 10^{2}$ & $3.60 \times 10^{3}$ \\
\hline 5.35 & 90 & 11.99 & $117 \pm 3$ & $1.60 \times 10^{2}$ & $1.40 \times 10^{4}$ & $2.39 \times 10^{3}$ \\
\hline 5.35 & 120 & 11.03 & $130 \pm 4$ & $1.00 \times 10^{2}$ & $1.10 \times 10^{4}$ & $1.69 \times 10^{3}$ \\
\hline 5.35 & 150 & 10.53 & $132 \pm 7$ & $4.00 \times 10^{1}$ & $1.80 \times 10^{4}$ & $2.73 \times 10^{3}$ \\
\hline 5.35 & 180 & 10.37 & $125 \pm 1$ & $1.60 \times 10^{2}$ & $1.70 \times 10^{4}$ & $2.72 \times 10^{3}$ \\
\hline 5.35 & 210 & 10.83 & $143 \pm 1$ & $1.10 \times 10^{2}$ & $1.10 \times 10^{4}$ & $1.54 \times 10^{3}$ \\
\hline 5.35 & 240 & 10.76 & $146 \pm 3$ & $6.00 \times 10^{1}$ & $3.60 \times 10^{4}$ & $4.93 \times 10^{3}$ \\
\hline 5.35 & 270 & 10.86 & $145 \pm 1$ & $2.00 \times 10^{1}$ & $9.00 \times 10^{3}$ & $1.24 \times 10^{3}$ \\
\hline 5.35 & 300 & 10.50 & $153 \pm 1$ & $8.00 \times 10^{1}$ & $1.00 \times 10^{4}$ & $1.31 \times 10^{3}$ \\
\hline 0 & 330 & 10.21 & $120 \pm 8$ & $1.50 \times 10^{1}$ & $5.00 \times 10^{4}$ & $8.33 \times 10^{3}$ \\
\hline 0 & 360 & 9.43 & $92 \pm 2$ & $1.60 \times 10^{2}$ & $4.70 \times 10^{5}$ & $1.02 \times 10^{5}$ \\
\hline 0 & 390 & 8.97 & $78 \pm 8$ & $1.10 \times 10^{2}$ & $8.80 \times 10^{5}$ & $2.26 \times 10^{5}$ \\
\hline 0 & 420 & 8.26 & $55 \pm 11$ & $1.70 \times 10^{2}$ & $4.50 \times 10^{5}$ & $1.64 \times 10^{5}$ \\
\hline 0 & 450 & 7.75 & $42 \pm 6$ & $1.20 \times 10^{2}$ & $6.50 \times 10^{5}$ & $3.10 \times 10^{5}$ \\
\hline
\end{tabular}

ESD: equivalent spherical diameter $\mathrm{n}=2$ for total suspended solids nd: no data 
A

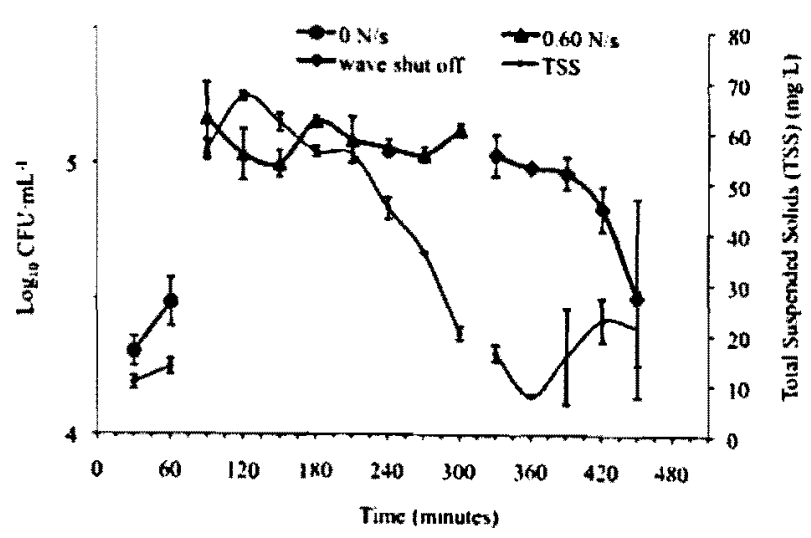

B

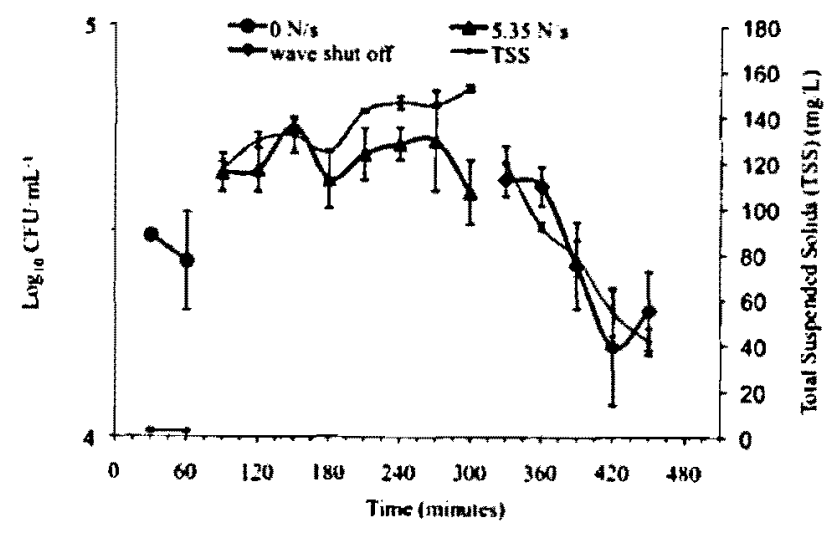

FIG. 13. Enumeration of floc-associated and free-floating Pseudomonas sp. strain CTO7::gfp-2 in water with low (A) and high (B) wave energy flux. Counts of test strain and suspended solids represent average ( $\mathrm{n}=3$ and $\mathrm{n}=2$, respectively).

As the larger particles settled towards the sediment bed, the higher number of cells associated with smaller flocs is likely due to a combination of physical, chemical, and biological mechanisms. It is possible that cells are actively attaching to the floc material when the kinetic energy of the system is reduced and there is decreased turbulence (time 330 to 450 minutes). Lawrence et al. (51) have shown that a bulk liquid flow velocity of $10 \mathrm{~cm} / \mathrm{s}$ was reduced to $200 \mu \mathrm{m} / \mathrm{s}$ at a distance of $2 \mu \mathrm{m}$ from the surface of a slide culture chamber, and allowed single Pseudomonas fluorescens cells to swim up-stream using flagellar-driven motility, Although this was reported for laminar flow conditions, the decrease in turbulence in the wave flume may allow for similar flagellardriven motility. Although not measured in this study, the surface charge of particles is also known to influence particle-particle interactions. Reduction of the electrochemical double layer through interactions between negative particles and positive cations can 
result in attraction and/or flocculation, thus affecting the number of cells associated with settling particles (63). A recent biofilm study using the same test strain from this study found that the average per cell $\mathrm{CO}_{2}$ production rate (measure of metabolic activity) was significantly higher for the shear-susceptible layer of cells that were removed with an air bubble and transferred to a planktonic state with an unrestricted access to nutrients and oxygen (7). Cells that associate with smaller flocs may benefit from increased diffusion of oxygen and may therefore be better suited to exploit nutrients found within the floc matrix.

The higher concentration of floc-associated cells after wave activity is a significant finding and has implications for beach management practices. Some beach sampling methods rely on traditional plate counts of indicator organisms, which assume that bacteria are mainly planktonic in nature (23). Sample analysis using this method may involve the use of membrane filtration in conjunction with a growth medium that allows for selection and enumeration of a particular indicator organism. Salhani and UelkeyDeffur (72) found that in order to accurately quantify viable aggregated bacteria, a pretreatment step was necessary, which involved incubation with a cellulase preparation combined with mechanical treatment such as ultrasonication. This pre-treatment resulted in the highest number of viable and culturable bacteria recovered from the effluent of a rotating drum bioreactor. While the enzymatic and mechanical treatment method resulted in a small percentage of injured or killed bacteria, it was deemed the most effective. In high wind or storm conditions, flocs may become re-suspended from the sediment bed, and when turbulence subsides or decreases the higher number of cells associated with the non-settling fraction along with the lack of sample pre-treatment may underestimate the 
true bacterial load in water. The application of molecular methods such as PCR and gene probes may allow for a more accurate determination of the bacterial load, however these methods also have their limitations. PCR is unable to distinguish viable from nonviable cells and gene probes may not be able to detect pathogens that are in low density in freshwater systems (84).

\subsection{6: Conceptual model of sediment-pathogen dynamics in lake systems: implications for beach management}

A summary of the erosion, transport and fate of bacteria in lake systems is provided in the conceptual model shown in Fig. 14. While this study used a nonpathogenic test organism, the transport properties also extend to pathogenic bacteria and indicator organisms. Pathogen erosion occurs when the bed shear stress (imparted by wind waves) is greater than the critical bed shear stress. Eroded pathogens may be either associated with floc material (silts, clays) or in their planktonic phase. If the fluid shear imparted by wind waves and water flow is greater than the floc shear strength, which is the force that must be applied to break up the floc, then floc-associated cells will dissociate. It is the dissociated cells (those linked with smaller flocs) along with the planktonic phase cells that remain in suspension due to turbulence or natural buoyancy. Bacteria attached to larger flocs are removed from the water column with the downward flux of larger particles. Suspended bacteria may undergo eventual reattachment due to flocculation or scavenging, and this concentration effect was observed when turbulence was removed from the system as described in 2.3.5. If the bed shear is not greater than the floc shear strength then larger flocs are deposited on the sediment bed and this leads 
to consolidation, compaction, and biofilm development. Alternatively, if the bed shear is greater than the floc shear strength, flocs will break up and be further transported.

\section{LAKE BED}

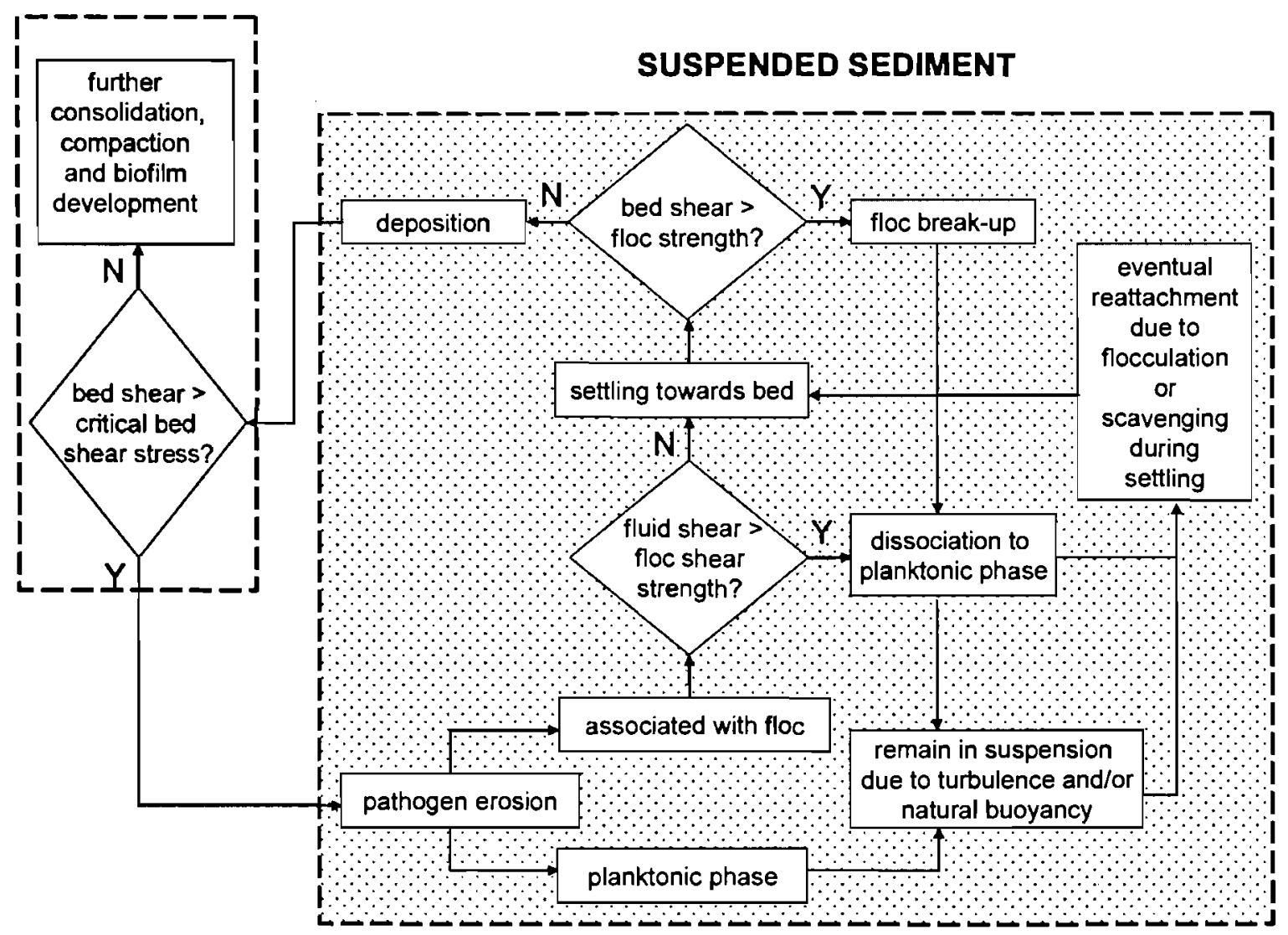

FIG. 14. Conceptual model of sediment-pathogen dynamics in lake systems. Bed shear refers to shear stress applied to the sediment bed (ie., imparted by wind waves). Critical bed shear stress refers to the shear stress at which particles will begin to move from the bed. Fluid shear is the stress imparted by wind waves and water flow. Shading in the suspended sediment box represents background bacterial population. Y: yes, N: no. Adapted from Droppo et al. (20).

This model highlights the transient nature of floc transport in freshwater systems and demonstrates the dynamic nature of cell-aggregate associations. It also highlights the 
importance of floc as a vector for pathogen transport in lake systems and the need to develop and utilize sampling methods that effectively break up floc and minimize cell damage in order to more accurately assess beach water quality. 


\section{CHAPTER 3: CONCLUSIONS AND FUTURE DIRECTIONS}

This study showed that a positive quantifiable correlation exists between shear (wave energy flux), total suspended solids, and bacterial loading in water. While the individual cell counts varied in the four trials, the consistent trend found between the variables tested in this study validated the use of the wave flume. It also highlighted the importance of using physical models in defined conditions to study the relationship between microbial loading and wave energy since interpretation of physical data from field studies is often difficult due to overlapping environmental variables.

The relationship between shear and the partitioning of free-floating and flocassociated bacteria was also demonstrated under low $(0.60 \mathrm{~N} / \mathrm{s})$ and high wave energy flux $(5.35 \mathrm{~N} / \mathrm{s})$. Under both energy regimes, there was an order of magnitude increase in the number of cells associated with floc material when turbulence was removed as compared to when waves were run continuously for $4 \mathrm{~h}$. The ability of cells to associate with floc under quiescent conditions has implications for beach water sample analysis, and demonstrates the importance of floc as a depository and vector for the mobilization of pathogenic bacteria and indicator organisms in freshwater systems. Current sample analysis methods assume that bacteria present in the water column are mainly planktonic in nature, which may underestimate the true suspended bacterial load. The results from this study imply the need to use or develop methods capable of assessing the contribution of bacteria from flocs to more accurately assess beach water quality.

Wave action may also influence bacterial growth and/or persistence in the water column, as nutrient loading of water in association with waves was observed for several macronutrients. The transport of the test strain through uninoculated beach sand within 
24 hours also demonstrated the ability for bacteria to move along wet to dry gradients, and highlighted the need to examine entire beach environments when assessing the quality of public beaches. In regards to sampling regimes, monitoring programs in the United States generally rely on one sample collected at the shoreline (76), while federal guidelines in Canada suggest that sediment samples should be collected only when there is evidence that bathing beaches could be the source of waterborne disease (29). Results from this study imply that further sampling may be necessary in order to more accurately assess public beach health.

Future work should focus on the differences in the composition of the indigenous microbial community in the free-floating and floc-associated fractions. These experiments could provide further insight to the potential relationship between flocassociated bacteria and changing environmental conditions (increasing wave energy regime). Denaturing gradient gel electrophoresis could be used to generate molecular fingerprints, and pertinent bands could be excised, cloned, and sequenced for phylogenetic analysis. These studies should be performed without using a test strain, as high concentrations of the test strain may result in PCR bias and also minimize the resolution of the indigenous microbial community on the polyacrylamide gel.

Experiments using a flow cell / shear cell to examine flocculation and floc breakup could provide insight to the potential release of floc-associated Pseudomonas sp. strain CTO7::gfp-2 under conditions of increasing shear. The flocs can first be eroded from the sediment bed using the wave flume at a specified wave energy flux and then be collected by pumping out the suspended sediment. Flocs could then be subjected to 
increasing shear using the flow cell / shear cell, and counts of the test organism could be determined using conventional methods.

In order to assess the degree of mixing of sediment-associated and suspended bacteria with wave action, two tracer organisms could be used. One organism could be tagged with GFP (emission peak at 508) or cyan fluorescent protein (CFP; emission peak at $477 \mathrm{~nm}$ ) and the other tagged with red fluorescent protein (RFP; emission peak at 583). It is important to choose two fluorescent proteins which have different excitation and emission bands in order to distinguish between them using epifluorescence microscopy or confocal laser scanning microscopy. Sediment and water could each be inoculated with one fluorescently-tagged organism and the degree of mixing could be determined with plate counts of water samples and sediment cores. Alternatively, flow cytometry could be used for the enumeration of the test strain. Flow cytometric analysis of Pseudomonas sp. strain CTO7::gfp-2 was investigated in a previous study (6), and an optimized procedure was determined that resulted in a good correlation between the number of fluorescent events measured with the cytometer and the viable cell count number. Microscopy would also be useful to visualize the extent of organism release and co-aggregation. 


\section{CHAPTER 4: REFERENCES}

1. Alm, E. W., J. Burke, and E. Hagan. 2006. Persistence and potential growth of the fecal indicator bacteria, Escherichia coli, in shoreline sand at Lake Huron. J. Great Lakes Res. 32:401-405.

2. Alm, E. W., J. Burke, and A. Spain. 2003. Fecal indicator bacteria are abundant in wet sand at freshwater beaches. Water Res. 37:3978-3982.

3. Avery, L. M., A. P. Williams, K. Killham, and D. L. Jones. 2008. Survival of Escherichia coli, $\mathrm{O} 157: \mathrm{H7}$ in waters from lakes, rivers, puddles and animal-drinking troughs. Sci. Total Environ. 389:378-385.

4. Baty, A., C. Eastburn, S. Techkarnjanaruk, A. Goodman, and G. Geesey. Spatial and temporal variations in chitinolytic gene expression and bacterial biomass production during chitin degradation. Appl. Environ. Microbiol. 66:3574-3585.

5. Bell, F. G. 1998. Environmental Geology: Principles and Practice. Blackwell Publishing, Oxford.

6. Bester, E., E. Edwards, and G. M. Wolfaardt. 2009. Planktonic cell yield is linked to biofilm development. Can. J. Microbio. 55:1195-1206.

7. Bester, E., O. Kroukamp, G. M. Wolfaardt, L. Boonzaaier, and S. N. Liss. 2010. Metabolic differentiation in biofilms as indicated by carbon dioxide production rates. Appl. Environ. Microbiol. 76:1189-1197.

8. Beversdorf, L. J., S. M. Bornstein-Forst, and S. L. McLellan. 2007. The potential for beach sand to serve as a reservoir for Escherichia coli and the physical influences on cell die-off. J. Appl. Microbiol. 102:1372-1381.

9. Bonilla, T. D., K. Nowosielski, M. Cuvelier, A. Hartz, M. Green, N. Esiobu, D. S. McCorquodale, J. M. Fleisher, and A. Rogerson. 2007. Prevalence and distribution of fecal indicator organisms in South Florida beach sand and preliminary assessment of health effects associated with beach sand exposure. Mar. Pollut. Bull. 54:1472-1482.

10. Brookes, J. D., J. Antenucci, M. Hipsey, M. D. Burch, N. J. Ashbolt, and C. Ferguson. 2004. Fate and transport of pathogens in lakes and reservoirs. Environ. Int. 30:741-759.

11. Buswell, C. M., Y. M. Herlihy, L. M. Lawrence, J. T. M. McGuiggan, P. D. Marsh, and C. W. Keevil. 1998. Extended survival and persistence of Campylobacter spp in water and aquatic biofilms and their detection by immunofluorescent-antibody and -rRNA staining. Appl. Environ. Microbiol. 64:733-741. 
12. Chynoweth, R. IV., J. A. Hudson, and K. Thom. 1998. Aerobic growth and survival of Campylobacter jejuni in food and stream water. Lett. Appl. Microbiol. 27:341-344.

13. City of Toronto. 2009. Great City, Great Beaches: Toronto Beaches Plan. 08-R-43630:.

14. Craun, G. F., R. L. Calderon, and M. F. Craun. 2005. Outbreaks associated with recreational water in the United States. Int. J. Environ. Health Res. 15:243-262.

15. Dedicu, L., J. Pages, and J. Bolla. 2008. The omp50 gene is transcriptionally controlled by a temperature-dependent mechanism conserved among thermophilic Campylobacter species. Res. Microbiol. 159:270-278.

\section{Dette, H. H., M. Larson, J. Murphy, J. Newe, K. Peters, A. Reniers, and H.} Steetzel. Application of prototype flume tests for beach nourishment assessment. Coastal Engineering. 47:137-177.

17. Dillon, P. J., and L. A. Molot. 1997. Dissolved organic and inorganic carbon mass balances in central Ontario lakes. Biogeochemistry. 36:29-42.

18. Droppo, I. G. 2001. Rethinking what constitutes suspended sediment. Hydrol. Process. 15:1551.

19. Droppo, I. G., C. Jaskot, T. Nelson, J. Milne, and M. Charlton. 2007. Aquaculture waste sediment stability: implications for waste migration. Water Air Soil Pollut. 183:5968.

20. Droppo, I. G., K. King, S. Tirado, A. Sousa, G. Wolfaardt, S. N. Liss, and L. Warren. 2010. Assessing riverine sediment-pathogen dynamics: implications for the management of aquatic and human health risk. In: Sediment Dynamics for a Changing Future, K. Banasik, A.J. Horowitz, P.N. Owens, M. Stone and D.E. Walling (Eds.). IAHS Publ. 337:245-250.

21. Droppo, I. G., G. G. Leppard, D. T. Flannigan, and S. N. Liss. 1997. The freshwater floc: a functional relationship of water and organic and inorganic floc constituents affecting suspended sediment properties. Water Air Soil Pollut. 99:43-53.

22. Droppo, I. G., S. N. Liss, D. Williams, and G. G. Leppard. 2006. River sediment/pathogen interactions: importance for policy development on safe water practices. IAHS Publ. 306:314-321.

23. Droppo, I. G., S. N. Liss, D. Williams, T. Nelson, C. Jaskot, and B. Trapp. 2009. Dynamic Existence of Waterborne Pathogens within River Sediment Compartments. Implications for Water Quality Regulatory Affairs. Environ. Sci. Technol. 43:1737-1743. 
24. Droppo, I. G., and E. D. Ongley. 1992. The state of suspended sediment in the freshwater fluvial environment: a method of analysis. Wat. Res. 26:65-72.

25. Droppo, I. G., and E. D. Ongley. 1994. Flocculation of suspended sediment in rivers of southeastern Canada. Water Res. 28:1799-1809.

26. Edge, T. A., and S. Hill. 2007. Multiple lines of evidence to identify the sources of fecal pollution at a freshwater beach in Hamilton Harbour, Lake Ontario. Water Rcs. 41:3585-3594.

27. Ellis, J. B., and W. Yu. 1995. Bacteriology of Urban Runoff - the Combined Sewer as a Bacterial Reactor and Generator. Watcr Sci. Technol. 31:303-310.

28. Environment Canada and the U.S. Environmental Protection Agency. 2009. State of the Great lakes 2009. 905-R-09-031.

29. Federal-Provincial Working Group on Recreational Water Quality (Canada). 1992. Guidelines for Canadian recreational water quality. Minister of National Health and Welfare, Ottawa.

30. Feng, P., R. Lum, and G. W. Chang. 1991. Identification of uidA gene sequences in $\beta$-D-glucuronidase-negative Escherichia coli Appl. Environ. Microbiol. 57:320-323.

31. Fogarty, L. R., S. K. Haack, M. J. Wolcott, and R. L. Whitman. 2003. Abundance and characteristics of the recreational water quality indicator bacteria Escherichia coli and enterococci in gull faeces. J. Appl. Microbiol. 94:865-878.

32. Francy, D. S., and R. A. Darner. 1999. Factors Affecting Escherichia coli Concentrations at Lake Erie Public bathing Beaches, IAGLR '99. A-33.

33. Garcia-Armisen, T., and P. Servais. 2009. Partitioning of Particle-Associated E. coli in River Waters. Water Environ. Res. 81:21-28.

34. Garneau, M. E., W. F. Vincent, R. Terrado, and C. Lovejoy. 2009. Importance of particle-associated bacterial heterotrophy in a coastal Arctic ecosystem. J. Marine Syst. $75: 185-197$.

35. Ginn, T. R., B. D. Wood, K. E. Nelson, T. D. Scheibe, E. M. Murphy, and T. P. Clement. 2002. Processes in microbial transport in the natural subsurface. Adv. Water Resour. 25: 1017-1042.

36. Halpern, M., O. Landsberg, D. Raats, and E. Rosenberg. 2007. Culturable and VBNC Vibrio cholerae: Interactions with chironomid egg masses and their bacterial population. Microb. Ecol. 53:285-293. 
37. Hartz, A., M. Cuvelier, K. Nowosielski, T. D. Bonilla, M. Green, N. Esiobu, D. S. McCorquodale, and A. Rogerson. 2008. Survival potential of Escherichia coli and enterococci in subtropical beach sand: Implications for water quality managers. J. Environ. Qual. 37:898-905.

38. Hendricks, C. W. 1971. Increased Recovery Rate of Salmonellae from Stream Bottom Sediments Versus Surface Waters. Appl. Environ. Microbiol. 21:379-380.

39. Heynen, C. E., J. D. Elsas, P. J. Kuikman, and J. A. Veen. 1988. Dynamics of Rhizobium leguminosarum biovar trifolii introduced into soil; the effect of bentonite clay on predation by protozoa. Soil Biol. Biochem. 20:483-488.

40. Howell, J. M., M. S. Coyne, and P. L. Cornelius. 1996. Effect of sediment particle size and temperature on fecal bacteria mortality rates and the fecal coliform. J. Environ. Qual. 25:1216-1220.

41. Ishii, S., D. L. Hansen, R. E. Hicks, and M. J. Sadowsky. 2007. Beach sand and sediments are temporal sinks and sources of Escherichia coli in lake superior. Environ. Sci. Technol. 41:2203-2209.

42. Ishii, S., T. Yan, D. A. Shively, M. N. Byappanahalli, R. L. Whitman, and M. J. Sadowsky. 2006. Cladophora (Chlorophyta) spp. harbor human bacterial pathogens in nearshore water of Lake Michigan. Appl. Environ. Microbiol. 72:4545-4553.

43. Iwamoto, M., G. Hlady, M. Jeter, C. Burnett, C. Drenzek, S. Lance, J. Benson, D. Page, and P. Blake. 2005. Shigellosis among swimmers in a freshwater lake. South. Med. J. 98:774-778.

44. Jamieson, R. C., R. J. Gordon, K. E. Sharples, G. W. Stratton, and A. Madani. 2002. Movement and persistence of fecal bacteria in agricultural soils and subsurface drainage water: A review. Canadian Biosystems Engineering. 44:1.1.

45. Jamieson, R. C., D. M. Joy, H. Lee, R. Kostaschuk, and R. J. Gordon. 2004. Persistence of enteric bacteria in alluvial streams. J. Environ. Eng. Sci. 3:203-212.

46. Ji, Z. 2008. Hydrodynamics and water quality: modeling rivers, lakes, and estuaries. Wiley-Interscience, Hoboken, N.J.

47. Kim, J. H., S. B. Grant, C. D. McGee, B. F. Sanders, and J. L. Largier. 2004. Locating sources of surf zone pollution: a mass budget analysis of fecal indicator bacteria at Huntington Beach, California. Environ. Sci. Technol. 38:2626-2636.

48. Kinzelman, J., S. L. McLellan, A. D. Daniels, S. Cashin, A. Singh, S. Gradus, and R. Bagley. 2004. Non-point source pollution: Determination of replication versus persistence of Escherichia coli in surface water and sediments with correlation of levels 
to readily measurable environmental parameters. Journal of Water and Health. 2:103114.

49. Kleinheinz, G. T., C. M. McDermott, M. C. Leewis, and E. Englebert. 2006. Influence of sampling depth on Escherichia coli concentrations in beach monitoring. Water Res. 40:3831-3837.

50. Kueh, C. S. W., T. Y. Tam, T. Lee, S. L. Wong, O. L. Lloyd, I. T. S. Yu, T. W. Wong, J. S. Tam, and D. C. J. Bassett. 1995. Epidemiologic-Study of SwimmingAssociated Illnesses Relating to Bathing-Beach Water-Quality. Water Sci. Technol. 31:14.

51. Lawrence, J. R., P. J. Delaquid, D. R. Korber, and D. E. Caldwell. 1987. Behavior of Pseudomonas fluorescens Within the Hydrodynamic Boundary Layers of Surface Microenvironments. Microb. Ecol. 14:1-14.

52. Lee, C. M., T. Y. Lin, C. C. Lin, G. A. Kohbodi, A. Bhattl, R. Lee, and J. A. Jay. 2006. Persistence of fecal indicator bacteria in Santa Monica Bay beach sediments. Water Res. 40:2593-2602.

53. Lemarchand, K., L. Masson, and R. Brousseau. 2004. Molecular Biology and DNA Microarray Technology for Microbial Quality Monitoring of Water. Crit. Rev. Microbiol. 30:145-172.

54. Lévesque, B., P. Brousseau, F. Bernier, E. Dewailly, and J. Joly. 2000. Study of the bacterial content of ring-billed gull droppings in relation to recreational water quality. Water Res. 34:1089-1096.

55. Marsalek, J., and Q. Rochfort. 2004. Urban wet-weather flows: Sources of fecal contamination impacting on recreational waters and threatening drinking-water sources. J. Toxicol. Env. Health Part A. 67:1765-1777.

56. Martins, M. T., I. G. Rivera, D. L. Clark, M. H. Stewart, R. L. Wolfe, and B. H. Olson. 1993. Distribution of uidA gene sequences in Escherichia coli isolates in water sources and comparison with the expression of $\beta$-glucuronidase activity in 4methylumbelliferyl- $\beta$-D-glucuronide media. Appl. Environ. Microbiol. 59:2271-2276.

57. McLellan, S. L., and A. K. Salmore. 2003. Evidence for localized bacterial loading as the cause of chronic beach closings in a freshwater marina. Water Research. 37:27002708 .

58. Mercer, J. R., R. M. Ford, J. L. Stitz, and C. Bradbeer. 1993. Growth rate effects on fundamental transport properties of bacterial populations. Biotechnol. Bioeng.

42:1277-1286. 
59. Muirhead, R. W., R. P. Collins, and P. J. Bremer. 2006. Interaction of Escherichia coli and soil particles in runoff. Appl. Environ. Microbiol. 72:3406-3411.

60. Muyzer G., De Wall E.C., and Uitterlinden A.G. 1993. Profiling of Complex Microbial Populations by Denaturing Gradient Gel Electrophoresis Analysis of Polymerase Chain Reaction-Amplified Genes Coding for 16S rRNA. Appl. Environ. Microbiol. 59:695-700.

61. Noble, R. T., I. M. Lee, and K. C. Schiff. 2004. Inactivation of indicator microorganisms from various sources of faecal contamination in seawater and freshwater. $\mathrm{J}$. Appl. Microbiol. 96:464-472.

62. Obiri-Danso, K., N. Paul, and K. Jones. 2001. The effects of UVB and temperature on the survival of natural populations and pure cultures of Campylobacter jejuni, Camp. coli, Camp. lari and urease-positive thermophilic campylobacters (UPTC) in surface waters. J. Appl. Microbiol. 90:256-267.

63. Ongerth, J. E., and J. P. Pecoraro. 1996. Electrophoretic mobility of Cryptosporidium oocysts and Giardia cysts. J Environ Eng. 123:228-231.

64. Ontario Ministry of Health. 2008. Beach Management Protocol. Queen's printer for Ontario. 978-1-4249-7599-0.

65. Oshiro, R., and R. Fujioka. 1995. Sand, Soil, and Pigeon Droppings - Sources of Indicator Bacteria in the Waters of Hanauma Bay, Oahu, Hawaii. Water Science and Technology. 31:251-254.

66. Papadakis, J. A., A. Mavridou, S. C. Richardson, M. Lampiri, and U. Marcelou. 1997. Bather-related microbial and yeast populations in sand and seawater. Water Res. 31:799-804.

67. Petersen, T. M., H. S. Rifai, M. P. Suarez, and A. R. Stein. 2005. Bacteria loads from point and nonpoint sources in an urban watershed. J. Environ. Eng. -ASCE. 131:1414-1425.

68. Prescott, L. M. 2002. Microbiology. McGraw-Hill, Toronto.

69. Pruss, A. 1998. Review of epidemiological studies on health effects from exposure to recreational water. Int. J. Epidemiol. 27:1-9.

70. Rahim, Z., S. I. Khan, and A. K. Chopra. 2004. Biological characterization of Aeromonas spp. isolated from the environment. Epidemiol. Infect. 132:627-636.

71. Ristow, P., P. Bourhy, S. Kerneis, C. Schmitt, M. Prevost, W. Lilenbaum, and M. Picardeau. 2008. Biofilm formation by saprophytic and pathogenic leptospires. Microbiology-(UK). 154:1309-1317. 
72. Salhani, N., and A. Uelker-Deffur. 1998. Improved quantification of aggregated bacteria by combined enzymatic and mechanical treatment of flocs and biofilm from a rotating drum bioreactor. Wat. Res. 32:1287-1295.

73. Sampson, R. W., S. A. Swiatnicki, C. M. McDermott, and G. T. Kleinheinz. 2005. E. coli at Lake Superior Recreational Beaches. J. Great Lakes Res. 31:116-121.

74. Schallenberg, M., P. J. Bremer, S. Henkel, A. Launhardt, and C. W. Burns. 2005. Survival of Campylobacter jejuni in water: Effect of grazing by the freshwater crustacean Daphnia carinata (Cladocera). Appl. Environ. Microbiol. 71:5085-5088.

75. Schijven, J., and A. M. D. Husman. 2006. A survey of diving behavior and accidental water ingestion among Dutch occupational and sport divers to assess the risk of infection with waterborne pathogenic microorganisms. Environ. Health Perspect. 114:712-717.

76. Scopel, C. O., J. Harris, and S. L. McLellan. 2006. Influence of nearshore water dynamics and pollution sources on beach monitoring outcomes at two adjacent Lake Michigan beaches. J. Great Lakes Res. 32:543-552.

77. Searcy, K. E., A. I. Packman, E. R. Atwill, and T. Harter. 2005. Association of Cryptosporidium parvum with suspended particles: Impact on oocyst sedimentation. Appl. Environ. Microbiol. 71:1072-1078.

78. Senderovich, Y., Y. Gershtein, E. Halewa, and M. Halpern. 2008. Vibrio cholerae and Aeromonas: do they share a mutual host? Isme J. 2:276-283.

79. Seyfried, P. L., R. S. Tobin, N. E. Brown, and P. F. Ness. 1985. A ProspectiveStudy of Swimming-Related Illness .1. Swimming-Associated Health Risk. Am. J. Public Health. 75:108-1070.

80. Stoodley, P., K. Sauer, D. G. Davies, and J. W. Costerton. 2002. Biofilms as complex differentiated communities. Annu. Rev. Microbiol. 56:187-209.

81. Stoodley, P., S. Wilson, L. Ilall-Stoodley, J. D. Boyle, H. M. Lappin-Scott, and J. W. Costerton. 2001. Growth and detachment of cell clusters from mature mixed-species biofilms. Appl. Environ. Microbiol. 67:5608-5613.

82. Turker, U., and M.S. Kabdash. 2006. The effects of sediment characteristics and wave height on shape-parameter for representing equilibrium beach profiles. J Ocean Eng. 33:281-291.

83. United States Environmental Protection Agency (U.S. EPA). 2003. Bacterial water quality standards for recreational waters (freshwater and marine waters) status report. EPA-823-R-03-008. 
84. United States Environmental Protection Agency (U.S. EPA). 2003. Managing Urban Watershed Pathogen Contamination. EPA/600/R-03/111:1-1.

85. United States Environmental Protection Agency (U.S. EPA). 2005. The EMPACT Beaches Project: Results From a Study on Microbiological Monitoring in Recreational Waters. EPA/600/R-04/023.

86. van Asperen, I. A., G. Medema, M. W. Borgdorff, M. J. W. Sprenger, and A. H. Havelaar. 1998. Risk of gastroenteritis among triathletes in relation to faecal pollution of fresh waters. Int. J. Epidemiol. 27:309-315.

87. Wade, T. J., N. Pai, J. N. S. Eisenberg, and J. M. Colford. 2003. Do US Environmental Protection Agency water quality guidelines for recreational waters prevent gastrointestinal illness? A systematic review and meta-analysis. Environ. Health Perspect. 111:1102-1109.

88. Wade, T. J., R. L. Calderon, K. P. Brenner, E. Sams, M. Beach, R. Haugland, L. Wymer, and A. P. Dufour. 2008. High sensitivity of children to swim ming-associated gastrointestinal illness - Results using a rapid assay of recreational water quality. Epidemiology. 19:375-383.

89. Walters, S. P., Gannon.V.P., and K. G. Field. 2007. Detection of Bacteroidales fecal indicators and the zoonotic pathogens E. coli O157:H7, Salmonella, and Campylobacter in river water. Environ. Sci. Technol. 41:1856-1862

90. Whitman, R. L., and M. B. Nevers. 2003. Foreshore sand as a source of Escherichia coli in nearshore water of a Lake Michigan beach. Appl. Environ. Microbiol. 69:55555562 .

91. Whitman, R. L., M. B. Nevers, and M. N. Byappanahalli. 2006. Examination of the watershed-wide distribution of Escherichia coli along southern Lake Michigan: an integrated approach. Appl. Environ. Microbiol. 72:7301-7310.

92. Whitman, R. L., M. B. Nevers, G. C. Korinek, and M. N. Byappanahalli. 2004. Solar and temporal effects on Escherichia coli concentration at a lake Michigan swimming beach. Appl. Environ. Microbiol. 70:4276-4285.

93. Whitman, R. L., D. A. Shively, H. Pawlik, M. B. Nevers, and M. N. Byappanahalli. 2003. Occurrence of Escherichia coli and enterococci in Cladophora (Chlorophyta) in nearshore water and beach sand of Lake Michigan. Appl. Environ. Microbiol. 69:4714-4719.

94. Williams, A. P., L. M. Avery, K. Killham, and D. L. Jones. 2007. Persistence, dissipation, and activity of Escherichia coli O157: $\mathrm{H7}$ within sand and seawater environments. FEMS Microbiol. Ecol. 60:24-32. 
95. Wolfaardt, G. M., M. J. Hendry, T. Birkham, A. Bressel, M. N. Gardner, A. J. Sousa, D. R. Korber, and M. Pilaski. 2008. Microbial response to environmental gradients in a ceramic\&hyphen;based diffusion system. Biotechnol. Biocng. 100:141149.

96. World Health Organization. 2003-. Guidelines for safe recreational water environments. World Health Organization, Geneva.

http:/www.who.int/water_sanitation_health/bathing/srwel/en/.

97. Wright, R. T. 2005. Environmental science: toward a sustainable future. Pearson/Prentice Hall, Upper Saddle River, N.J.

98. Wu, J., P. Rees, S. Storrer, K. Alderisio, and S. Dorner. 2009. Fate and transport modeling of potential pathogens: the contribution from sediments. JAWRA. 45:35-44.

99. Yamahara, K. M., B. A. Layton, A. E. Santoro, and A. B. Boehm. 2007. Beach sands along the Califomia coast are diffuse sources of fecal bacteria to coastal waters. Environ. Sci. Technol. 41:4515-4521. 


\section{CHAPTER 5: APPENDIX}

\section{1: Validation of flume experiments}

It was necessary to verify that an even distribution of test organism was layed down in the flume after mixing it with Sunnyside Beach sediment for 10 minutes in a cement mixer. Sterile sediment cores were taken far upshore (transect 4; see Fig. 3), at the water line, and at the swash zone, and the top $2 \mathrm{~cm}$ were analyzed as described in 2.3.4. As seen in Fig. 15 samples collected in all three zones were not significantly different $(p<0.05)$, as determined with a paired t-test.

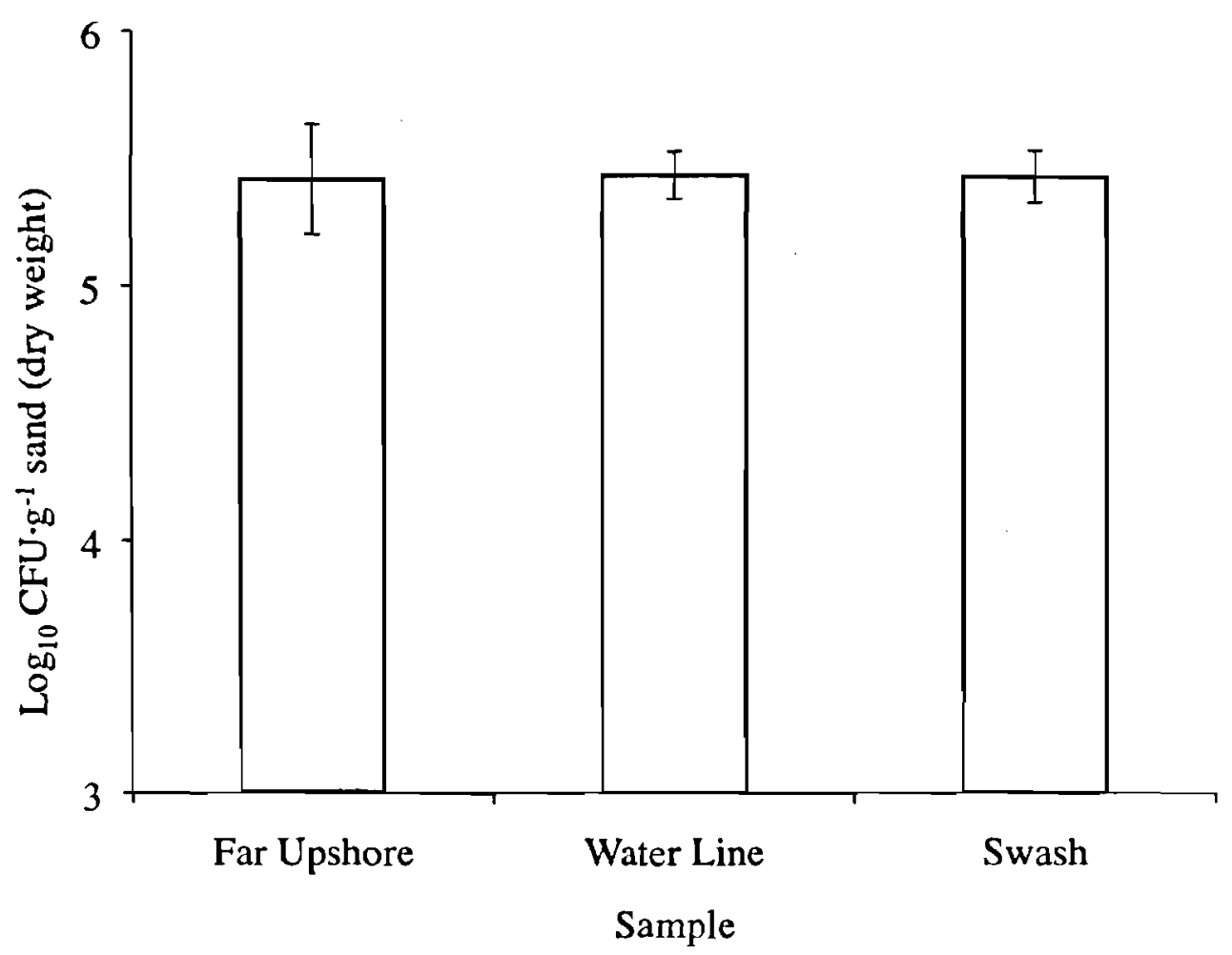

FIG. 15: Validation of mixing procedure used to produce a sediment with a homogenous mix of Pseudomonas sp. strain CTO7::gfp-2. 
To ensure that the increase in cell numbers in the water column was due to resuspension imparted by wave action and not cell division, batch experiments using Hamilton Harbour water were conducted in triplicate $250 \mathrm{~mL}$ Erlenmeyer flasks in a shaking incubator at $250 \mathrm{r} / \mathrm{min}$. Samples were collected every two hours and analyzed as described in 2.3.4. As seen in Fig. 16 cell numbers were not significantly different $(p<$ 0.05 ) during the 8 hour testing period, as determined with paired t-tests.

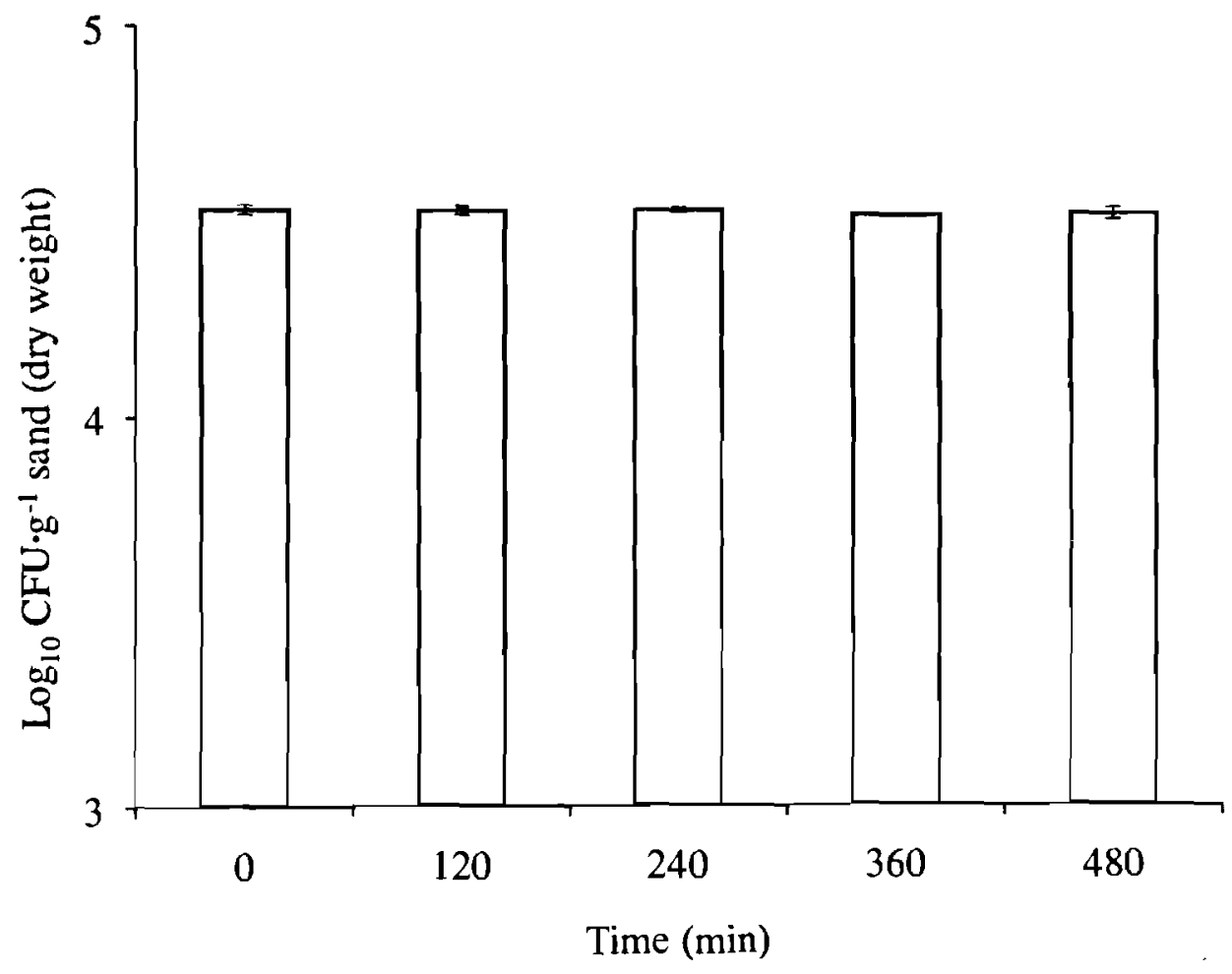

FIG. 16: Validation that increased cell numbers was associated with wave action rather than cell division. 


\section{2: Optimization of sample analysis times}

To determine the approximate percentage of cells removed from sand grains using the procedure described in 2.3.4, triplicate samples were vortexed for $30,60,90,120$, and finally 150 seconds (Fig. 17). Vortexing the sand grain sample for 30 seconds corresponded to an approximate $80 \%$ cell removal. Longer vortex times may have caused cell lysis.

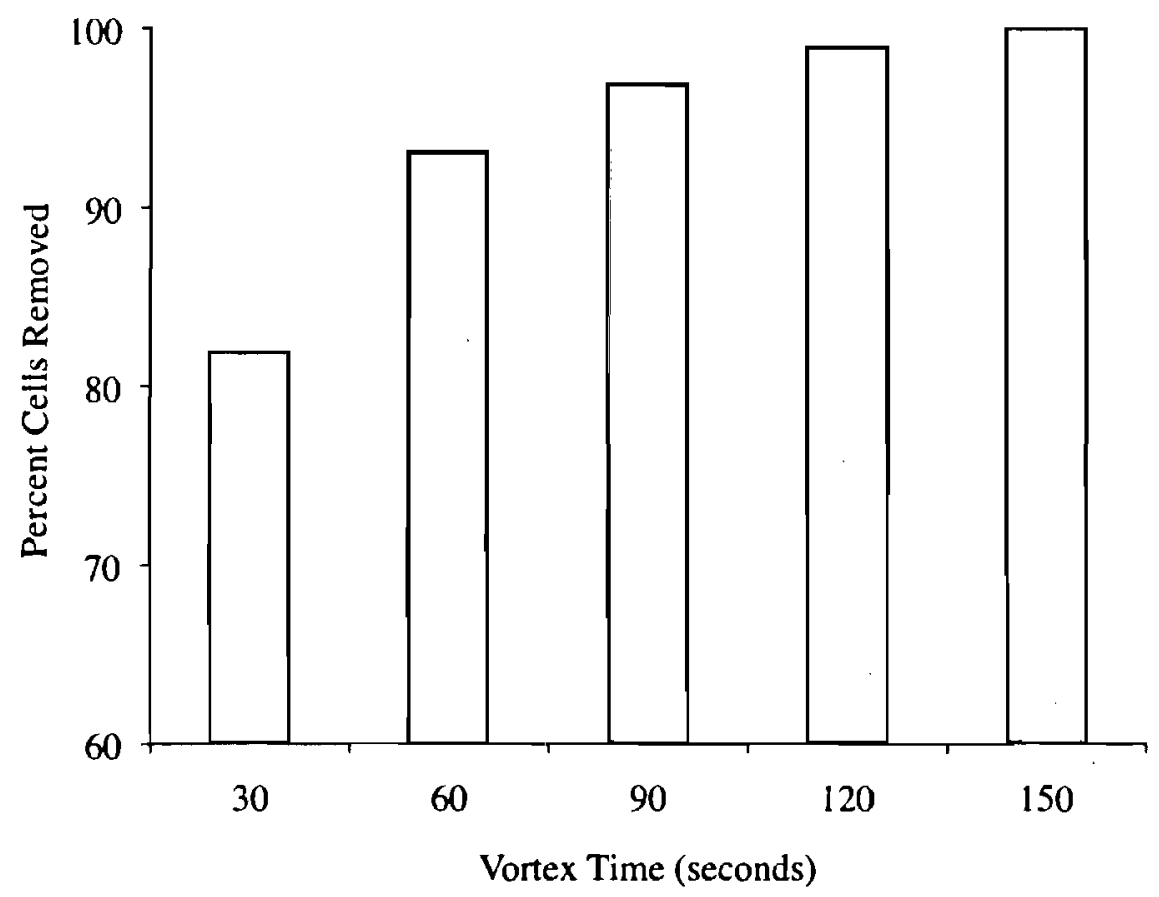

FIG. 17: Optimization of vortex time used to remove Pseudomonas sp. strain CTO7::gfp2 from sand grains.

To determine the optimal sonication time that allowed for effective break-up of floc and minimized cell death, a water sample was sonicated from 30 to 240 seconds and analyzed as described in 2.3.4. The optimal sonication time was determined to be 1 
minute, since well dispersed colonies were observed and cell numbers decreased with sonication times greater than 1 minute (Fig. 18).

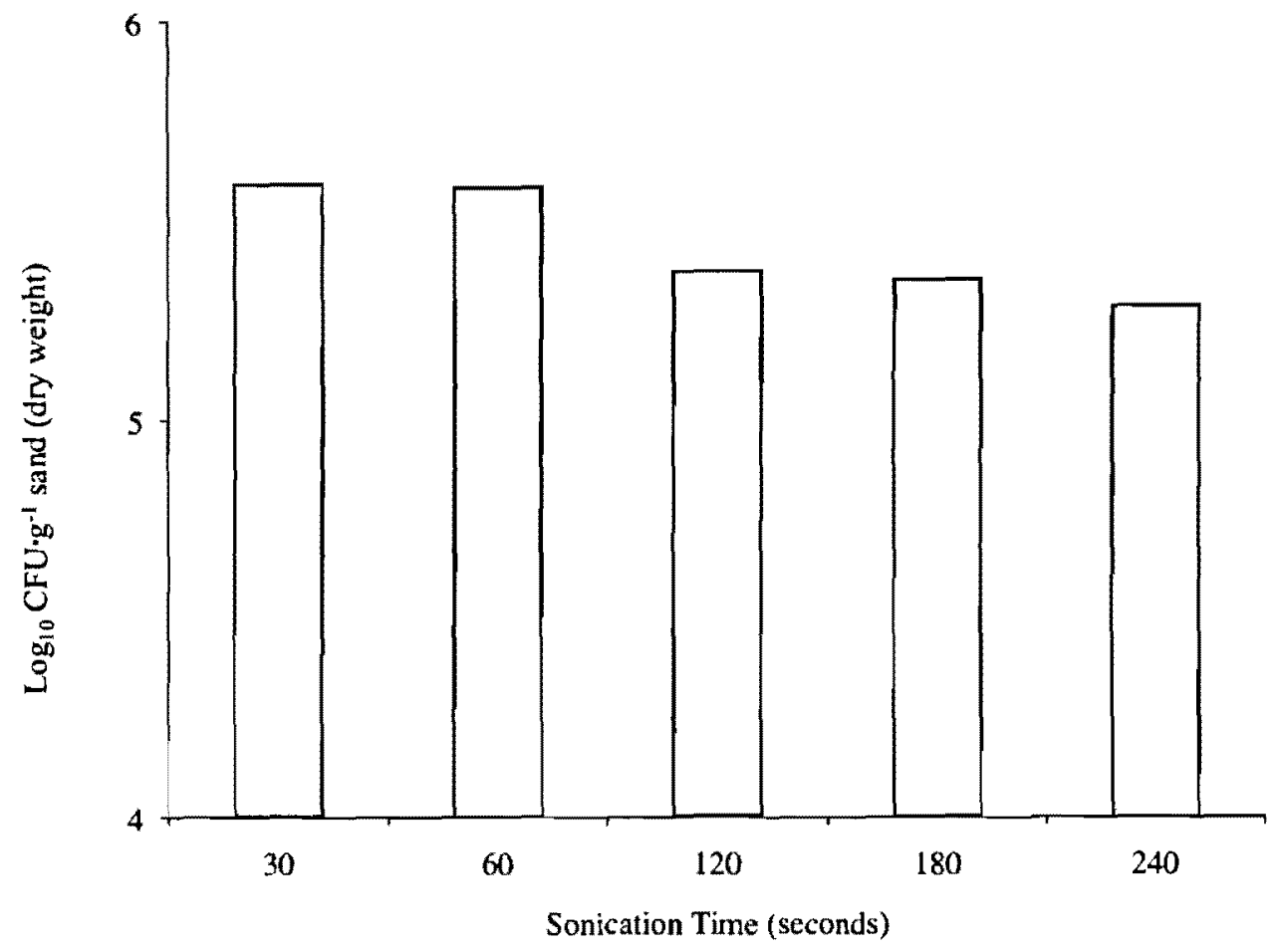

FIG. 18: Optimization of sonication time used to break up flocs containing Pseudomonas sp. strain CTO7::gfp-2.

5.3: PCR amplification of bacterial 16S rRNA gene from Sunnyside Beach sand and Hamilton Harbour water

The $1.0 \%$ agarose gel containing the $16 \mathrm{~S} \mathrm{rRNA}$ gene fragments from Sunnyside Beach sand and Hamilton Harbour water can be viewed in Fig. 19. Samples were quantified by generating a standard curve of the $100 \mathrm{bp}$ marker using Chemimager 4400 software. 


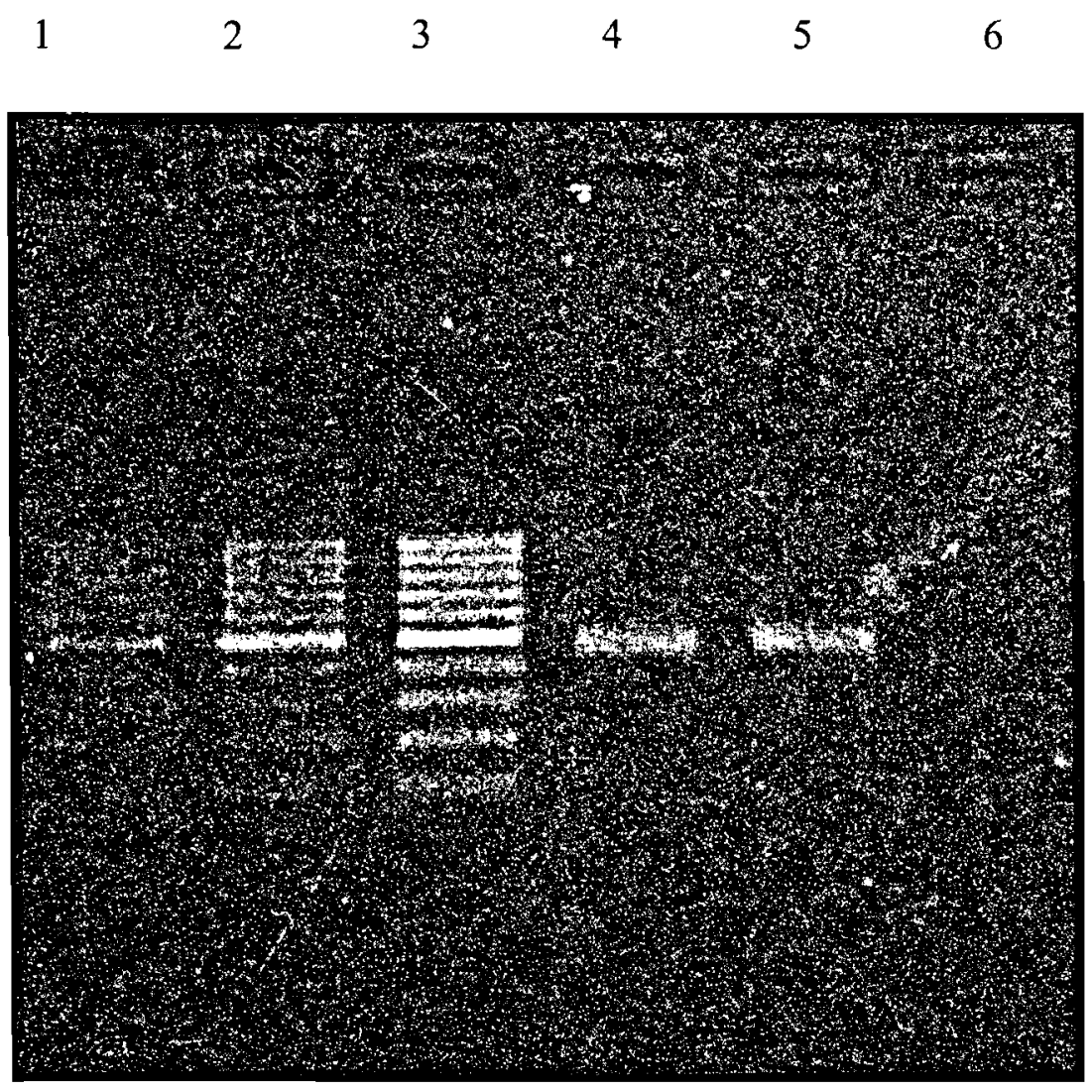

FIG. 19. 1.0\% agarose gel showing $16 \mathrm{~S}$ rRNA PCR products from Sunnyside Beach sand

(4) and Hamilton Harbour water (5). 100 bp molecular weight marker at 11.5, 23, $46 \mathrm{ng}$ $(1,2,3$, respectively), negative control (6).

\section{4: Effect of increasing shear on sediment-associated bacteria (trials 2 to 4)}

\subsection{1: Trial 2}

Erosion of the test strain from the sediment bed with increasing wave energy flux was also observed in trial 2 (Fig. 20). This was most pronounced for transect 1, which roughly corresponded to the wave breaking zone. Unlike in trial 1 (see 2.3 .4 ), transect 3 
(air-sediment-water interfacial zone) showed a concentration of bacteria in the top $2 \mathrm{~cm}$ of the sediment bed with increasing wave energy flux (Fig. 20d).
A) Transect 1
B) Transect 2
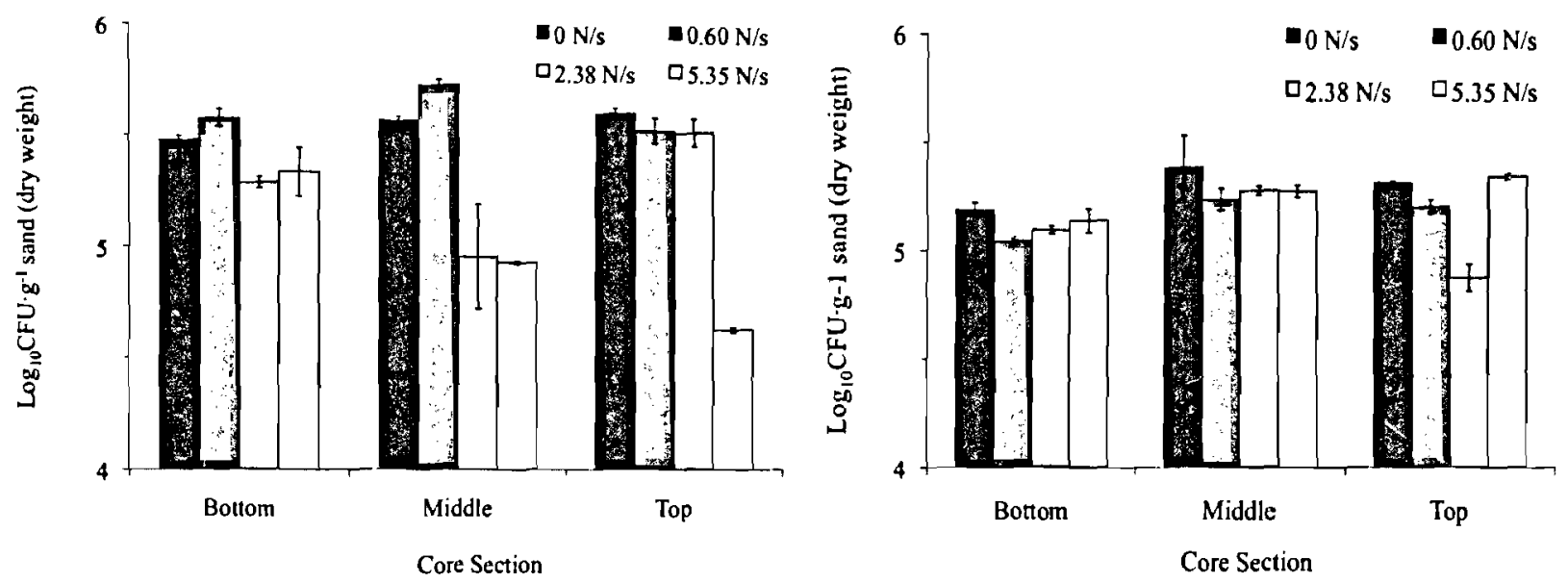

C) Transect 4

D) Transect 3
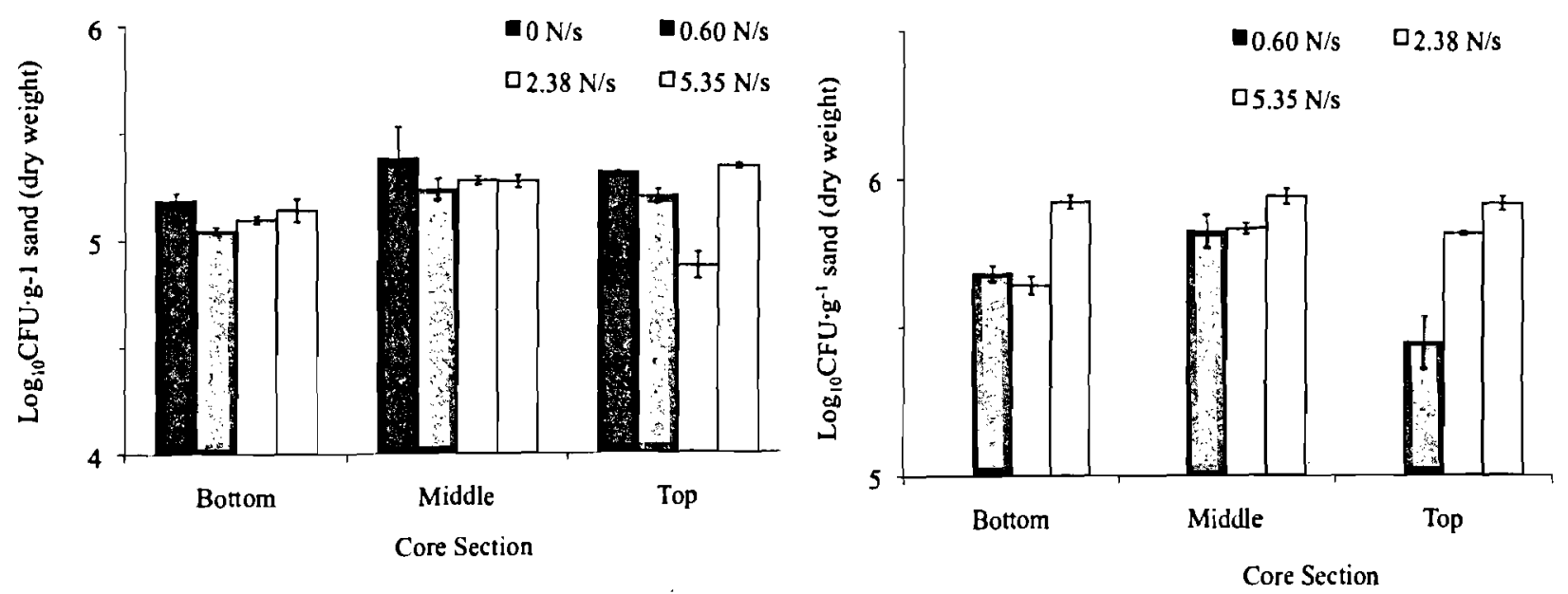

FIG. 20. Enumeration of Pseudomonas sp. strain CTO7::gfp-2 from sand cores taken along four beach transects (trial 2). A) Transect $1\left(\mathrm{~T}_{1}\right)$ refers to below water line, and was roughly the wave breaking zone. $\mathrm{B})$ Transect $2\left(\mathrm{~T}_{2}\right)$ refers to the swash zone, which was the area where the shoreline moves back and forth as waves meet the shore. C) Transect 4 
was the far upshore region of the beach beyond the furthest point of wave movement. D) Transect $3\left(\mathrm{~T}_{3}\right)$ characterized the air-water-sediment interface, and was the furthest area where water travelled up the beach when waves were run. The exact location of transect 3 varied with wave energy, as higher wave energies pushed water further up the beach. Bottom and top refer to the enumeration of the test strain from $6 \mathrm{~cm}$ and $2 \mathrm{~cm}$ below the surface of the sediment bed. Counts of test strain represent average $(n=2)$.

\subsection{2: Trial 3}

Erosion was most pronounced for transect 2, which roughly corresponded to the swash zone (Fig. 21b). The air-sediment-water interface was not characterized in this trial. 
A) Transect 1

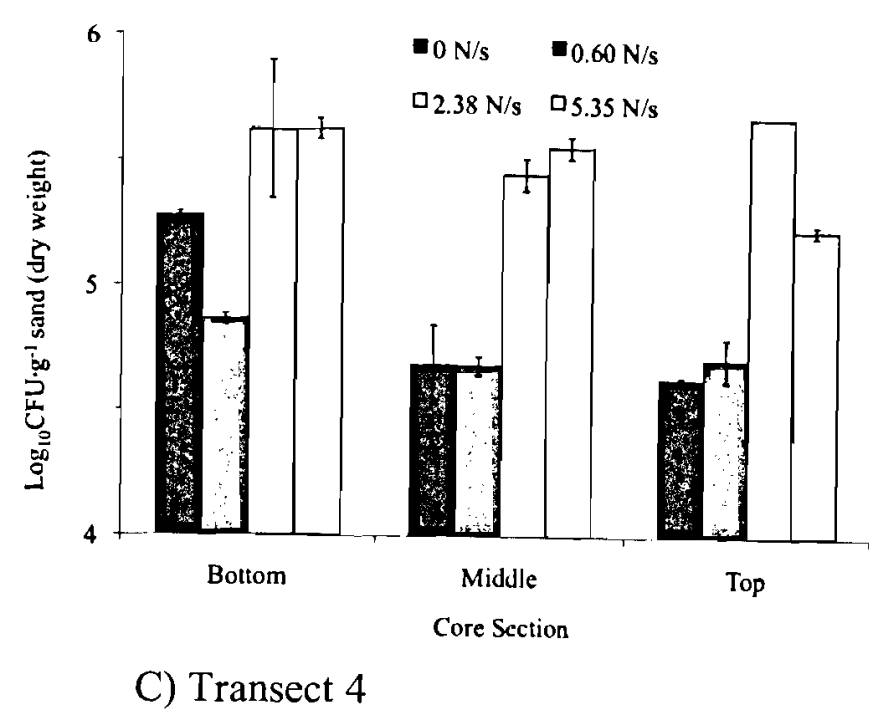

B) Transect 2

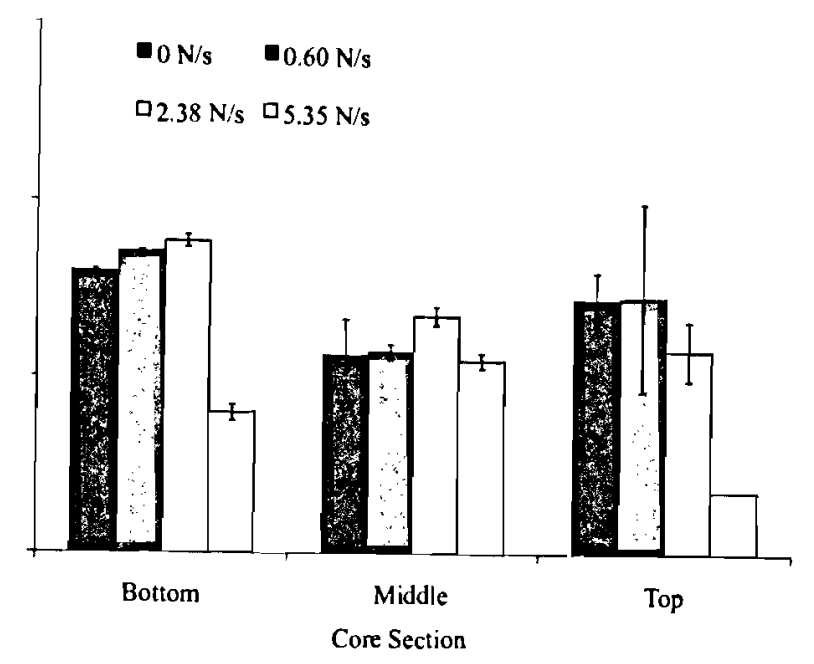

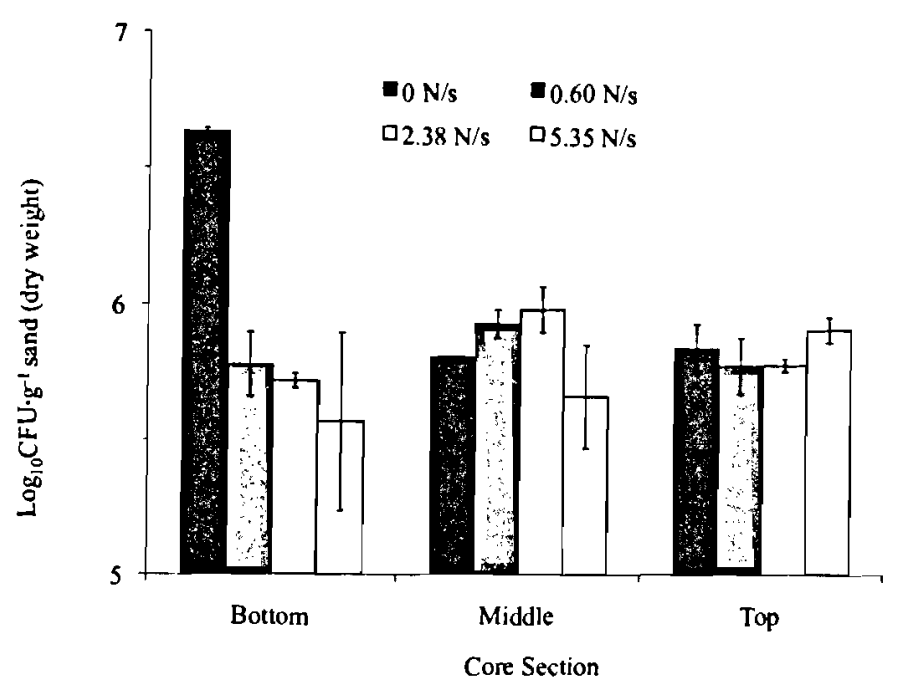

FIG. 21. Enumeration of Pseudomonas sp. strain CTO7::gfp-2 from sand cores taken along four beach transects (trial 3). A) Transect $1\left(T_{1}\right)$ refers to below water line, and was roughly the wave breaking zone. B) Transect $2\left(\mathrm{~T}_{2}\right)$ refers to the swash zone, which was the area where the shoreline moves back and forth as waves meet the shore. C) Transect 4 
was the far upshore region of the beach beyond the furthest point of wave movement. Bottom and top refer to the enumeration of the test strain from $6 \mathrm{~cm}$ and $2 \mathrm{~cm}$ below the surface of the sediment bed. Counts of the test strain represent average $(\mathrm{n}=2)$.

\subsection{3: Trial 4}

Erosion of test strain from the sediment bed was most pronounced for transects 1 , 2 and 4 , which roughly corresponded to the wave breaking zone, swash zone, and far upshore region, respectively. Transect 3 (air-sediment-water interfacial zone) showed a slight concentration of bacteria in the top $2 \mathrm{~cm}$ of the sediment bed with increasing wave energy flux (Fig. 22d), however this effect was not as pronounced as in trial 2 (see 5.4.1). 
A) Transect 1
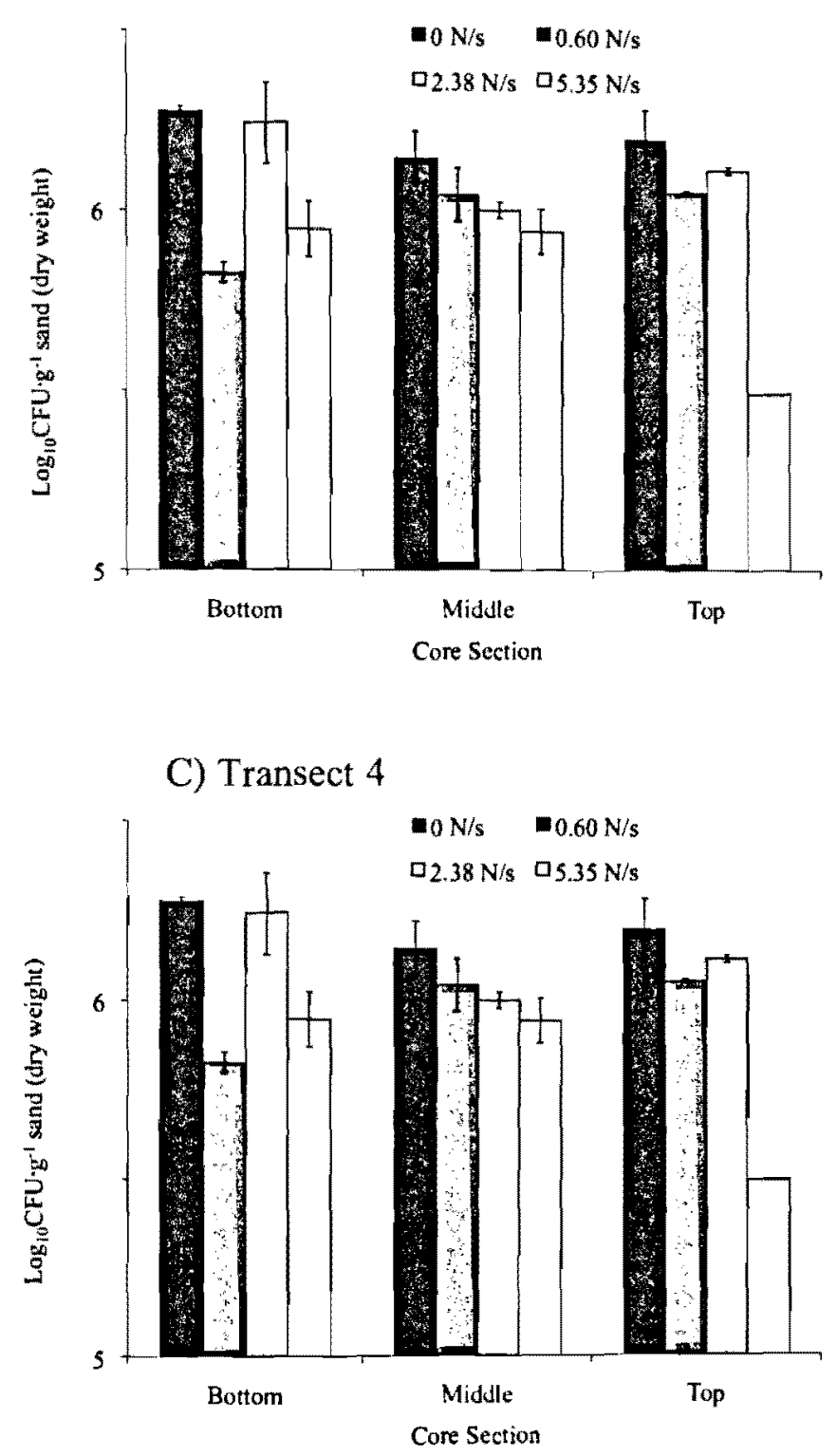

B) Transect 2

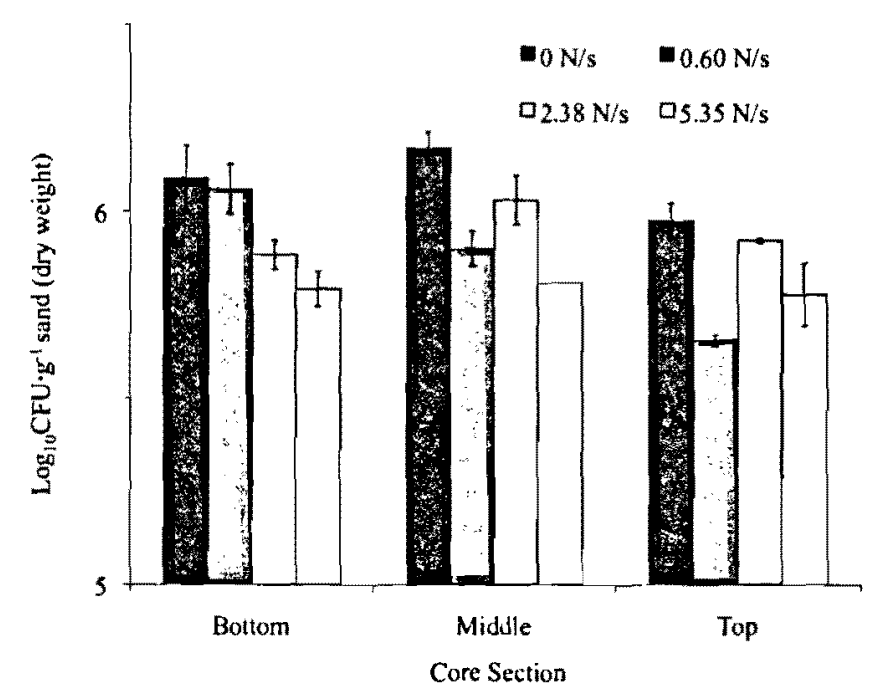

D) Transect 3

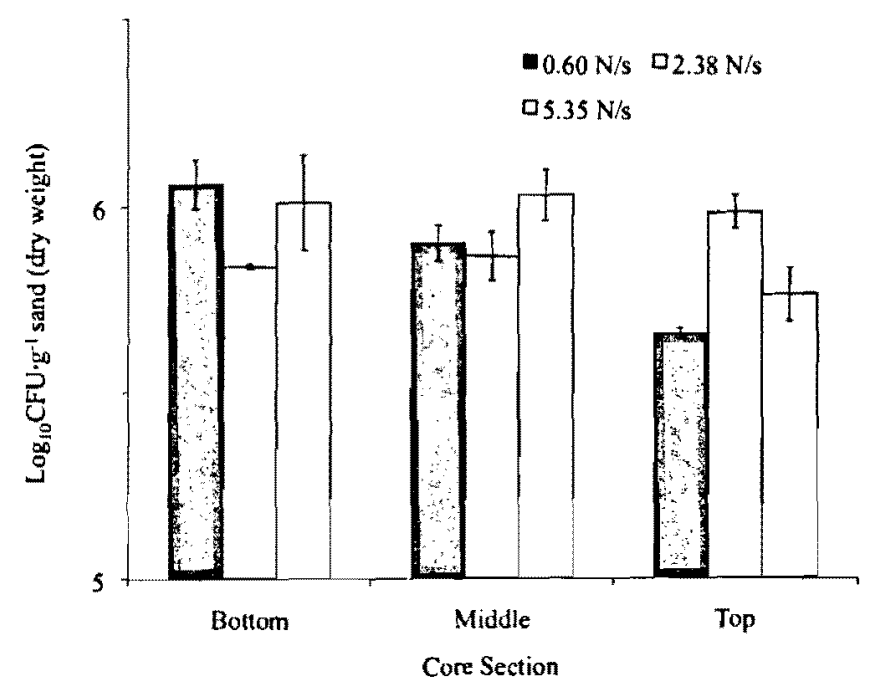

FIG. 22. Enumeration of Pseudomonas sp. strain CTO7::gfp-2 from sand cores taken along four beach transects (trial 4). A) Transect $1\left(\mathrm{~T}_{1}\right)$ refers to below water line, and was roughly the wave breaking zone. $\mathrm{B})$ Transect $2\left(\mathrm{~T}_{2}\right)$ refers to the swash zone, which was the area where the shoreline moves back and forth as waves meet the shore. C) Transect 4 was the far upshore region of the beach beyond the furthest point of wave movement. D) 
Transect $3\left(\mathrm{~T}_{3}\right)$ characterized the air-water-sediment interface, and was the furthest area where water travelled up the beach when waves were run. The exact location of transect 3 varied with wave energy, as higher wave energies pushed water further up the beach.

Bottom and top refer to the enumeration of the test strain from $6 \mathrm{~cm}$ and $2 \mathrm{~cm}$ below the surface of the sediment bed. Counts of the test strain represent average $(n=2)$. 